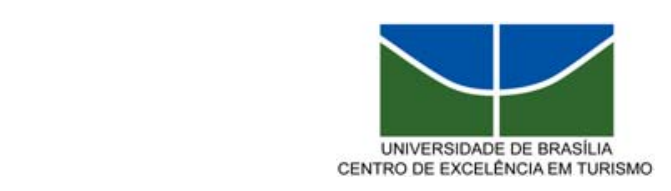

UNIVERSIDADE DE BRASÍLIA-UNB

CENTRO DE EXCELÊNCIA EM TURISMO - CET

CURSO: TURISMO: CULTURA E LAZER

\title{
RECREAÇÃO E LAZER: CONHECENDO A TRIBO DOS “RPGISTAS”
}

\section{ALYNE RÉGIA RIBEIRO DE OLIVEIRA}

\begin{abstract}
Monografia apresentada ao Centro de Excelência em Turismo da Universidade de Brasília como requisito parcial para obtenção do certificado de Especialista em Turismo: cultura e lazer.
\end{abstract}

Brasília/DF, junho/2005 


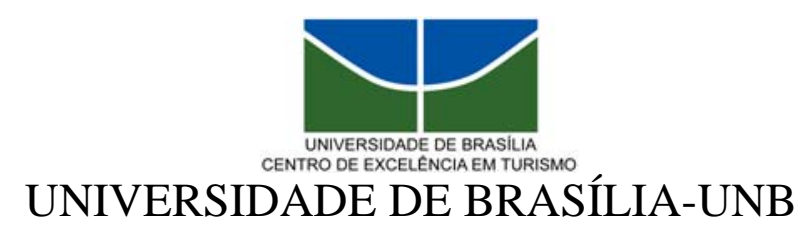

CENTRO DE EXCELÊNCIA EM TURISMO-CET

CURSO: TURISMO: CULTURA E LAZER

\title{
RECREAÇÃO E LAZER: CONHECENDO A TRIBO DOS "RPGISTAS"
}

\section{ALYNE RÉGIA RIBEIRO DE OLIVEIRA}

\author{
Banca Examinadora:
}

Prof_(a) orientador(a)

Prof_(a) membro 
ALYNE RÉGIA RIBEIRO DE OLIVEIRA

\section{RECREAÇÃO E LAZER: CONHECENDO A TRIBO DOS “RPGISTAS"}

Comissão Avaliadora

Professor Orientador

Brasília/DF, junho/2005 
"O homem sábio é aquele que sabe alguma coisa sobre tudo e tudo sobre alguma coisa. Estuda como se fosse viver eternamente e vive como se fosse morrer amanhã.”

Láo Tse 
À minha mãe,

Pessoa que muito amo e que está sempre ao meu lado para me dar esperança e força em todas as minhas conquistas $\mathrm{E}$ que cada dia se mostra mais e mais, revelando ser muito especial e querida. 
Agradeço,

A Deus, luz que ilumina e fortalece meus passos e decisões. Por Ele ter me tornado uma pessoa forte e persistente, atributos tão necessários para a realização deste trabalho.

À minha querida mãe, pessoa que mais acredita em mim, porque nunca mediu esforços para me fazer feliz e está sempre me dando forças em tudo que faço.

Ao meu pai, ao meu irmão, aos meus avós, a minha madrinha, ao meu padrinho e a todos os familiares e amigos que fizeram parte de toda a minha formação, possibilitando que eu chegasse onde estou hoje.

Em especial àqueles que estiveram na correria junto comigo, atrás de material ou dando caronas, nesse caso destacam-se a Márcia e a Kelly. Toda essa turma esteve tão firme comigo ou com minhas idéias que não me permitiam ao menos cansar ou descansar.

Ao Bruno Benitz e ao Gualter Henrique, grandes conhecedores do assunto e entrevistados para esta pesquisa, por estarem sempre a disposição. Especialmente ao segundo que foi a pessoa que mais contribuiu para a realização desta pesquisa.

Á todos os colegas "rpgistas" que responderam todas as minhas interrogações, e estas não foram poucas, seja através dos questionários, nas observações ou em conversas descompromissadas, mas que muito me ensinaram sobre este jogo do qual tanto gosto.

Aos colegas de turma que foram grandes companheiros durante o curso e na 
escolha do tema. Aos colegas da Carvalhaw Marketing, empresa onde trabalho, pela compreensão e apoio. Aos colegas da $5^{\mathrm{a}}$ zona eleitoral, local de trabalho da minha mãe, por toda a força que me deram.

Ao Professor Marcelo de Brito, meu orientador e desorientador, que abraçou a este tema e a mim com tanto carinho e dedicação e que em nossos "papos" e "devaneios" me ajudou a compreender o que realmente estava fazendo e quais os caminhos devia trilhar para tornar este trabalho um sucesso.

E à Professora Dulce Suassuna, coordenadora deste curso, pois esteve sempre à disposição, foi companheira, solidária, e que tanto contribui para o sucesso do mesmo. 


\section{RESUMO}

A ampliação do tempo livre tem propiciado cada vez mais o desenvolvimento de atividades relacionadas com o entretenimento. E mesmo que na história da humanidade a importância dada às atividades hedônicas sempre tenha existido, na sociedade pósindustrial essa importância tem se mostrado cada vez maior. Isto se deu com a conquista de maior tempo livre e com o desejo de consumir que veio suprir os desejos e realizações do imaginário do ser humano. Ao que se sabe o lazer tem função compensatória das contenções diariamente sofridas pelo trabalhador ou por aquele que é massacrado a viver nos padrões do sistema. Assim muitos buscam por atividades que as satisfaçam. Os jovens e adultos de Brasília/DF têm se utilizado de uma atividade recreativa, o Role Playing Game - RPG, para suprir suas necessidades de lazer. Este grupo geralmente tem um tempo livre maior, uma vez que, são em sua maioria estudantes, porém estão tão fadigados com as exigências e padrões estabelecidos pela sociedade que passaram a jogar RPG como válvula de escape. Seus hábitos, estilos e pensamentos e ainda a busca dos mesmos pelo lúdico faz com que estes se caracterizem em uma tribo urbana. Tribo esta que vem crescendo e que está encontrando no jogo uma maneira de projetar-se e de projetar os seus desejos. Sendo assim o RPG tem cumprido para seus praticantes as funções principais de uma atividade de lazer oferecendo-lhes: descanso, diversão e desenvolvimento. 


\section{LISTA DE SIGLAS}

RPG - Role Playing Game, traduzido no Brasil como: jogo de representação de personagens.

DF - Distrito Federal.

B.B. - Bruno Benitz

G.H. - Gualter Henrique

D\&D - Dungeons and Dragons, traduzido no Brasil como: Masmorras e Dragões.

EUA - Estados Unidos da América.

GURPS - Generic Universal Role Play System, traduzido no Brasil como: sistema universal de RPG genérico.

AD\&D - Advanced Dungeos and Dragons.

UNESCO - Organização das Nações Unidas para a educação

3D\&T - Defensores de Tóquio $3^{\circ}$ edição.

PC - Player Character, traduzido como: personagem jogador.

NPC - Non-player Character, traduzido como: personagem não jogador.

PVs - Pontos de vida.

PMs - Pontos de magia. 


\section{LISTA DE TABELAS}

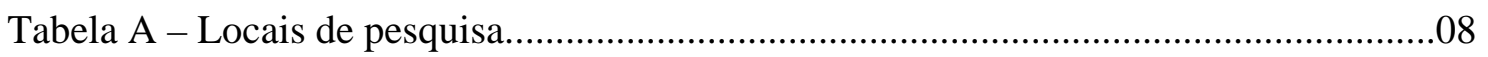

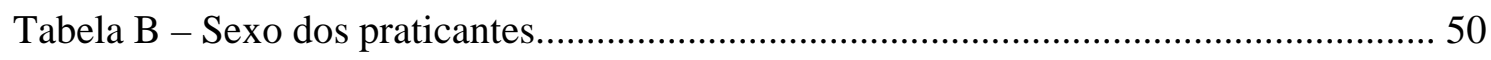

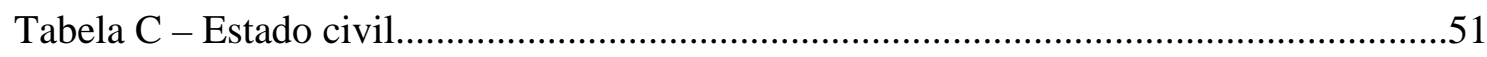

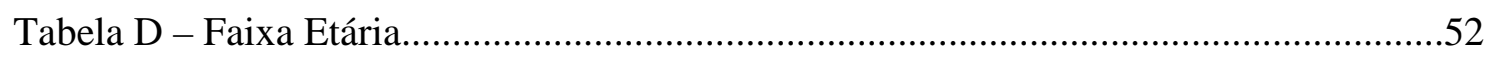

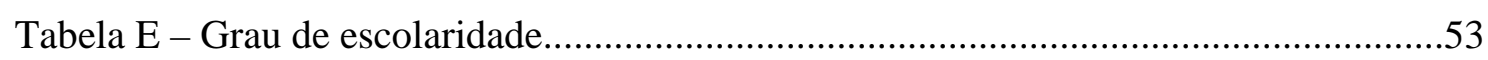

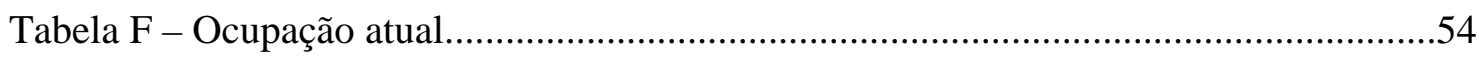

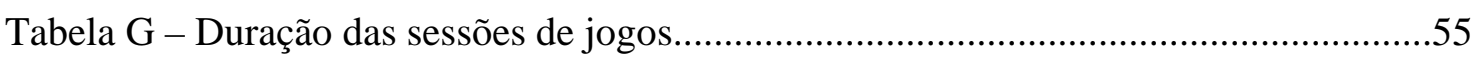

Tabela H - Freqüência de jogos semanais....................................................................56

Tabela I - Quantidade de pessoas com quem jogam..........................................................57

Tabela J - Envolvimento com organizações ou projetos relacionados ao RPG...................58

Tabela L - Nível de importância do RPG.....................................................................59

Tabela M - Motivações para jogar RPG..........................................................................61 


\section{LISTA DE GRÁFICOS}

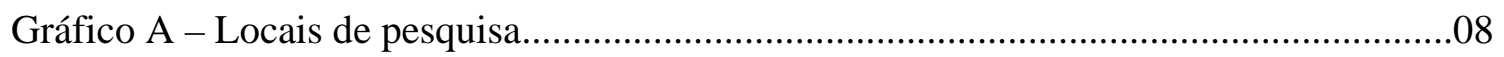

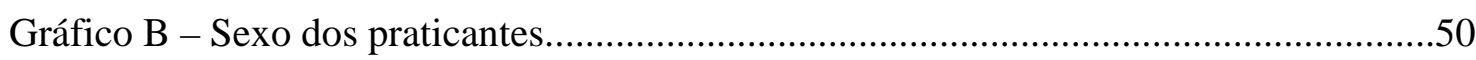

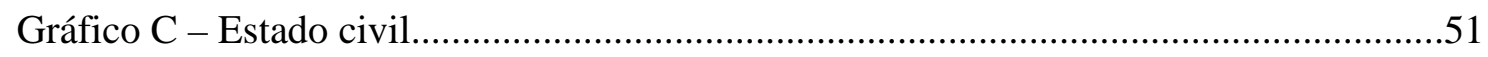

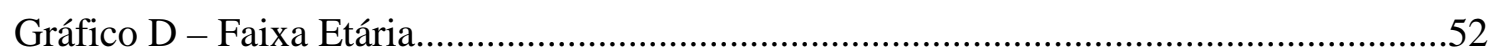

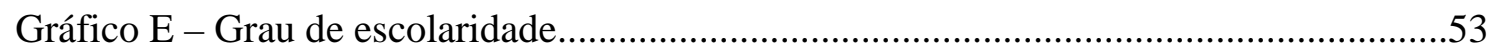

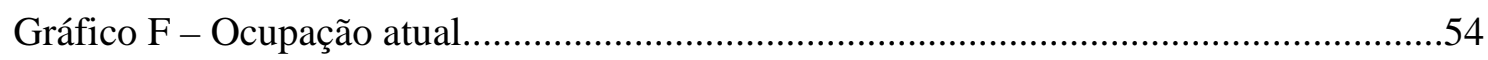

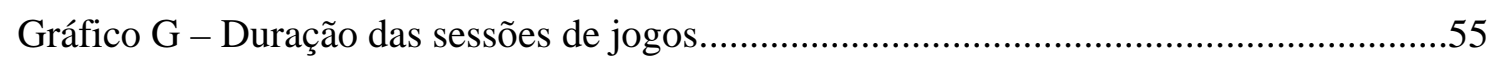

Gráfico H - Freqüência de jogos semanais.....................................................................56

Gráfico I - Quantidade de pessoas com quem jogam...................................................57

Gráfico J - Envolvimento com organizações ou projetos relacionados ao RPG.................59

Gráfico L - Nível de importância do RPG....................................................................60

Gráfico M - Motivações para jogar RPG..................................................................62 
SUMÁRIO

1. INTRODUÇÃO..................................................................................................................01

2. REFERENCIAL TEÓRICO..................................................................................09

2.1. As bases históricas do lazer............................................................................................09

2.2. Questão do tempo livre dos jovens................................................................................16

2.3. Conhecendo o RPG...........................................................................................21

2.4. A "Viagem" do RPG …………………........................................................................24

2.5. O Lúdico e o RPG.............................................................................................28

2.6. A Tribo Urbana do RPG...............................................................................................32

2.6.1. Apropriação de espaços urbanos pela tribo dos rpgsitas .........................................38

2.6.2. A linguagem própria do rpgista..................................................................................40

2.6.3. A representação e a construção de personagens.......................................................42

2.7. O RPG Sociologia do Lazer ..........................................................................................44

3. APRESENTAÇÂO DOS DADOS..................................................................................47

3.1. Entrevistas......................................................................................................................47

3.2. Questionários.........................................................................................................50

3.3 Observação in loco.................................................................................................63

4. INTERPRETAÇÃO DOS DADOS..............................................................................66

5. TESTE DA HIPOTESE..............................................................................................68

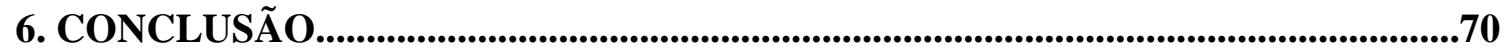

7. SUGESTÕES..............................................................................................................72

8. BIBLIOGRAFIA........................................................................................................73

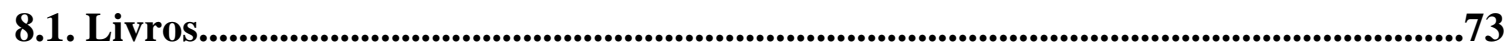

8.2. Web Sites..............................................................................................................74

8.3. Periódicos.................................................................................................................75

8.4. Bibliografia Complementar..............................................................................................75 


\section{INTRODUÇÃO}

Este trabalho tem o interesse de estudar o Role Playing Game - Jogo de Interpretação de Personagem (RPG) como forma de recreação, tentando abordar, mais especificamente, o jogo RPG como instrumento de recreação e divertimento para o público acima de 12 anos de Brasília - Distrito Federal (DF). Tudo isso no intuito de compreender como o RPG se tornou uma atividade compensatória de tensões cotidianas para seus praticantes e tentar conhecer melhor o jogador traçando um perfil que permita esclarecer algumas informações relevantes a respeito do mesmo e de grande importância para ampliar os estudos na área do lazer.

Este estudo ora apresentado aborda especificamente a questão do tempo livre, principalmente dos jovens, e de como este está sendo utilizado para a prática do jogo RPG. A pesquisa realizada tem a pretensão de compreender como a atividade vem se tornando uma prática mais comum entre os jovens, o que eles buscam e esperam do mesmo, quais são suas características e suas aspirações.

A primeira parte desta monografia trata do tempo livre, e tenta fazer a evolução da conquista deste tempo por parte do homem, demonstrando a maneira como ele passou a ser visto e utilizado, mas não só pelos trabalhadores, e sim também por jovens que muitas vezes só possuem a obrigação de estudar, e que não por isso, não devam gozar do tempo liberado, uma vez que as rotinas escolares de hoje exigem um grande esforço do estudante, massacrando-o com metas e tentando torná-lo cada vez mais competitivo.

É, ainda, apresentado neste estudo dados relativos ao Role Playing Game, tais como: processo histórico, surgimento do jogo, estrutura e administração de organizações, tipos de jogos, entre outras informações. São apresentados alguns dados coletados através de entrevistas e questionários que objetivaram conhecer melhor os jogadores.

A segunda parte aborda definições que permeiam o tema em questão, entre elas a noção de jogo, recreação, do fantasiar, e do que é o lúdico, tentando esclarecer como estas se apresentam dentro das atividades de lazer , em destaque na prática do RPG, e sua função como válvula de escape que permite uma fulga de questões cotidianas.

Todas essas abordagens tentarão subsidiar o leitor acerca do universo dessa prática indicando a forma que o RPG tem se expandido entre o público praticante em Brasília e quem são estes jogadores. Mostrando também como se dá a influência das 
relações sociais, a apropriação de espaços, a utilização de linguagem específicas para tratar de assuntos do jogo e de como estes pontos dão aos praticantes uma caracterização de tribo urbana.

\section{Justificativa}

O assunto aqui discutido foi escolhido primeiramente pelo meu interesse e familiaridade com o RPG no intuito de conhecer este cenário e de aliar os meus conhecimentos técnicos e profissionais na área do lazer a uma prática recreativa pessoal.

Optou-se por estudar o Lazer e a utilização do tempo livre, que cada vez mais vem sendo conquistado pelo homem. Tendo como fator primordial conhecer quem são os indivíduos praticantes de RPG, destacando seus interesses e características comuns e analisando no que esta prática interferiu em suas vidas.

Subjacentemente, tentar entender de que maneira as ocupações no tempo disponível do homem tem sofrido mudanças recentes, quando os indivíduos estão deixando de lado a vida focada no trabalho e passando a se atentar com questões pessoais como uma vida mais saudável e o lazer. Como nos mostra Camargo (1998:10): "não é mais somente o trabalho que preocupa as pessoas. Em nome da qualidade de vida, a diversão e o gozo lúdico da existência também se torna um problema a ser resolvido pelos indivíduos e uma fonte de cobrança da família e dos amigos.”

Na minha visão, existe ainda, uma necessidade de divulgar e promover o jogo como uma opção de lazer, e mostrar para as pessoas a importância do RPG como um instrumento de sociabilização, aprendizado e diversão para aqueles que o praticam. Tentando clarear certas visões que se têm a respeito dos jogadores e do jogo, idéias estas que surgiram por causas dos temas dos que envolvem o RPG, como por exemplo, o mundo sobrenatural, o ocultismo, o misticismo e o fantástico, assuntos sempre polêmicos, além é claro de notícias empregadas pela mídia, principalmente televisiva, ligadas a crimes que relacionam o jogo e seus praticantes.

Casos noticiados por várias emissoras de tevê, destacando-se a Rede Globo, que veiculou desde outubro de 2001, notícias que envolvem problemas onde jogadores de RPG, que se envolveram em assassinatos, destacando aqui o caso de uma garota de Ouro 
Preto em Minas Gerais morta supostamente por um grupo que transformou a história de um jogo de RPG em realidade.

Outro aspecto que vem justificar a importância desta pesquisa é a expansão deste jogo no que concerne ao mercado, agregando a esta atividade lúdica produção literária, jogos eletrônicos, souvenirs, camisetas, músicas, entre outros. Tudo na intenção de alcançar um entendimento à respeito dos jogadores, personagens sociais que representam e como estes aderiram à pratica do jogo RPG.

\section{Problema de Pesquisa}

O RPG enquanto atividade de lazer que apresenta acentuado componente representativo estaria se constituindo, num espaço-tempo, como meio compensatório das pressões sofridas nas sociedades e no meio urbano, atraindo indivíduos com perfil e características existenciais semelhantes?

\section{Objetivos}

\section{Objetivo Geral}

Investigar o perfil do jogador de RPG de Brasília-DF para compreender qual o papel desta atividade recreativa suas vidas.

Objetivos Específicos

- Levantar informações gerais sobre os jogadores e sobre os espaços destinados às partidas de jogos;

- Analisar a importância do RPG para seus praticantes;

- Identificar possíveis relações entre os interesses comuns dos praticantes e o jogo de RPG;

\section{Formulação da Hipótese}


- O jogo é mais popular entre os jovens, que buscam na representação de personagens a possibilidade de evasão e alívio de tensões estabelecidas pela sociedade. Estes possuem experiências pessoais e características culturais em comum e disponibilizam de tempo e dedicação para atividades relacionadas ao jogo, tendo, quase sempre, sua vida pessoal e social influenciada e/ou afetada pela prática do jogo podendo-se afirmar que os mesmos vivem numa subcultura deste grupo em específico.

\section{Metodologia}

É fácil perceber que o processo de pesquisa deve ser encarado como uma construção, e toda construção deve ser baseada em métodos, possibilitando uma continuidade da obra, até porque a ciência é uma fonte inesgotável. É como afirma, Popper citado por Lakatos e Marconi (2001:95) “(...) a ciência começa e termina com problemas.”

O que se pretende aqui é mostrar os procedimentos utilizados e os caminhos pelos quais foi possível a realização deste estudo.

Quanto aos objetivos, as ferramentas aqui adotadas são: o contato com praticantes do RPG e, principalmente, de caráter exploratório, ou seja, este estudo foi realizado através de pesquisa bibliográfica, pois, de acordo com Gil (1991:45), “estas pesquisas tem como objetivo proporcionar maior familiaridade com o problema, com vistas a torná-las mais explicito ou a construir hipóteses. Pode-se dizer que estas pesquisas têm como objetivo principal o aprimoramento de idéias ou a descoberta de intuições.” A busca de informações em fontes bibliográficas se dá especialmente pela necessidade de fundamentação teórica que argumente este estudo, esta é desenvolvida através de material já elaborado, em especial, livros e artigos científicos relacionados ao tema.

O procedimento de coleta de dados se deu através de pesquisa documental, que de acordo com Rosiu, et al (2003: 23) é a pesquisa de informações em documentos que ainda não receberam um tratamento analítico e/ou publicação, com a intenção de conhecer melhor o jogo, este estudo se deu principalmente em livros de RPG e outros materiais das organizações das quais participam os jogadores do mesmo.

Quanto às fontes de informações, utilizou-se aqui a bibliográfica com extensa pesquisa em fontes de informação já publicadas, destacando o livro de Sonia RodriguesRoleplaying Game e a pedagogia da imaginação no Brasil - a primeira tese elaborada 
sobre o tema do país e a primeira a ser publicada, além de diversos outros autores que se destacam na área do lazer e recreação, e de outras produções acadêmicas já elaboradas; buscou-se, ainda, bastante informação em campo, com a observação de grupos e do comportamento das pessoas e de suas atividades no que diz respeito à prática do jogo RPG, foi possível conhecer um pouco melhor a dinâmica deste e a maneira como seus praticantes se envolvem com o mesmo.

Métodos de abordagem

Com o interesse de conhecer melhor o jogador de RPG e o dinamismo e influência do jogo sobre o praticante, o método de abordagem escolhido para desenvolver esta investigação científica foi o hipotético-dedutivo, uma vez que ele parte de um problema, passa por hipóteses, para chegar a uma conclusão e validação ou negação das pseudo-respostas.

Popper, citado por Lakatos e Marconi (2001:95) defende as seguintes etapas do processo de investigação:

“1. Problema, que surge, em geral, de conflitos
ante expectativas e teorias existentes; 2.
Solução proposta consistindo numa conjectura
(nova teoria); dedução de conseqüências na
forma de proposições passíveis de teste. 3.
Testes de falseamento: tentativas de refutação,
entre outro meios, pela observação e
experimentação.”

Esta pesquisa possui todas essas características e procura aqui testar hipóteses que poderão ser respostas temporárias às questões levantadas, temporárias porque, diferente do método indutivo, este método percebe a ciência como algo continuo e passível de mudança, é importante ainda lembrar que este estudo esta sendo feito em um período de tempo, destina uma geração, que inclui na sua maioria jovens, e que são passíveis de mudança quanto ao seu comportamento e seus interesses pelo jogo.

É importante ainda ressaltar que hipóteses são pseudo-respostas à questão que se busca responder, ou seja, é a oferta de soluções possíveis às problemáticas. Gil (1991:35) 
afirma que hipótese é "uma expressão verbal suscetível de ser declarada verdadeira ou falsa (...).” E as autoras Lakatos e Marconi citado por Lima (1999:126) nos dá outra definição: "Podemos considerar hipóteses como um enunciado geral de relações entre variáveis (fatos, fenômenos)”, então percebe-se que hipóteses são proposições testáveis que podem vir a ser a solução do problema proposto. Eis por que a escolha deste método de abordagem: tenta-se nesta pesquisa estudar a fundo definições e aspectos que possam solucionar o problema colocado em questão neste momento, ou seja, através de hipóteses tenta-se conhecer o praticante do jogo RPG deste período, de novembro de 2004 à maio de 2005, em que foi realizado.

Métodos de procedimento

Aqui busca-se explicar como o objeto de estudo vai ser analisado neste trabalho. Segundo Lakatos e Marconi, citado por Lima (1999:51), os procedimentos “Constituem etapas mais concretas da investigação (...) Pressupõem uma atitude concreta em relação ao fenômeno estão limitadas a um domínio particular.”

Neste caso, os procedimentos utilizados focaram, primeiramente, aspectos históricos, foi necessário compreender o contexto em que estava inserido o objeto de estudo em questão, conhecer o jogo, como ele chegou ao Brasil e como foi aceito por seus praticantes, uma vez que para jogar há exigências que o mesmo impõe para seus jogadores, exemplo disto é a carga de leitura que o praticante costuma fazer para poder jogar.

Outro procedimento de coleta de informações foi o estudo de campo. Este se dá, de acordo com Rosiu, et al (2003:23) a partir do recolhimento de dados 'in natura' Buscou-se analisar o tema RPG como instrumento de recreação, tendo como base a prática do próprio jogo tentando observar todas as situações e aspectos referentes ao mesmo e levantando informações diretamente em grupos específicos relacionados aos interesses desta pesquisa.

Técnicas de pesquisa 
Tendo necessidade de levantar informações sobre o praticante de RPG e sobre as atividades realizadas pelos mesmos em locais de jogos, optou-se pela realização de entrevistas, observações in loco e aplicação de questionários.

Foram realizadas entrevistas com profissionais e conhecedores do assunto, com o objetivo de conhecer melhor os praticantes de RPG, esclarecendo como se desenvolvem as suas atividades e responder às questões levantadas neste estudo. Esta técnica de pesquisa foi utilizada com o intuito de levantar elementos da história dos praticantes, porque, como afirmam os autores Freire e Pereira, citado por Murta e Albano (2002:124) “(...) o grande mérito da história oral é poder dar conta, como nenhuma outra metodologia, da complexidade da realidade permitindo que seja recriado a multiplicidade original de pontos de vista.”

Importante para conseguir aprofundar à situação em que se encontra o panorama geral do RPG em Brasília, duas entrevistas foram realizadas para a elaboração deste estudo, elas proporcionaram vislumbrar inicialmente as opiniões pessoais de dois jogadores que estão diretamente ligados a realização de jogos na cidade.

O primeiro entrevistado, o qual chamaremos de B.B., já pratica esta atividade há alguns anos e está a frente de um grupo de jogadores que fazem parte de uma organização voltada para o RPG, o Brasília by night, promovendo jogos de RPG - live actions (jogos com ação ao vivo), há muitos anos na cidade. B. conseguiu trazer para este trabalho uma visão geral a respeito de como os jogadores de Brasília se envolvem com o jogo, qual o seu estilo de vida e relações sociais vinculadas ao RPG.

O segundo entrevistado, G.H., que joga RPG há pelo menos 7 anos, e também está a frente de um grupo de jogadores que fazem parte de uma organização que promove jogos de RPG - live actions, o fã clube oficial da editora White Wolf, popularmente conhecido como The Camarilla, e registrado no Brasil como a Associação Brasileira de Jogadores de RPG. Gualter transmitiu informações abrangentes a respeito do jogo e jogadores e de como acontece a comunicação entre estes, a utilização de gírias nas conversas a respeito do jogo entre outras.

Além das entrevistas, foi utilizada também nesta pesquisa a técnica de observação in loco, pois se acredita que esta técnica é apropriada para alcançar os objetivos propostos neste trabalho. Isto porque observando o comportamento dos 
jogadores e como se dá as suas atividades, pode-se conhecer como se dá a o processo de recreação através do jogo RPG. Esta técnica de pesquisa já vinha sendo realizada meses antes da pesquisa, permitiram inclusive a participação no jogo. $\mathrm{O}$ intuito maior da observação foi familiarizar com o tema.

Na verdade a técnica de observação permite conhecer a realidade como ocorre no momento de realização dos jogos e das relações referentes à ele. Conforme Gil (1991:40): “(...) O estabelecimento assistemático de relações entre os fatos no dia-a-dia é que fornece os indícios para a solução dos problemas propostos pela ciência (...)”. Além disso, porque de acordo com Lima (1999:51) o mesmo “(...) utiliza os sentidos na obtenção de determinados aspectos da realidade. Consiste em examinar todos os fenômenos que se deseja estudar.”

Quantos aos questionários foram aplicados um total de 30 em locais estratégicos como lojas dos segmentos e espaços utilizados para a prática dos jogos. Com o objetivo de conhecer melhor e levantar informações sobre jogadores, suas atividades, seus interesses e outras questões que contribuíram para a realização desta pesquisa.

Assim foram aplicados em três locais de Brasília, 10 deles na loja Kingdom Comics, localizada no Setor de Diversões Sul; outros 10 questionários na loja Mundo do RPG, localizada no Shopping Pátio Brasil - Quadra 701 Sul; e 20 questionários no SESC da Quadra 504 Sul. Esses três locais foram escolhidos pela sua grande utilização por jogadores para praticas dos jogos, encontro com os amigos para conversarem a respeito do jogo e por dois deles, a Kingdom Comics e a Mundo do RPG, venderem produtos especificamente voltados para a prática do RPG.

\section{Universo e amostra}

Segue abaixo tabela que melhor explica os pontos de aplicação dos questionários aplicado nos principais pontos de encontro entre os jogadores de RPG de Brasília - DF: Local da entrevista:

TABELA A - Locais de pesquisa

Local Número de questionários aplicados $\quad$ Percentual




\begin{tabular}{ccc}
\hline Loja Kingdom Comics & 10 & $25 \%$ \\
Loja Mundo do RPG & 10 & $25 \%$ \\
SESC 504 Sul & 20 & $50 \%$ \\
\hline Total & 40 & $100 \%$ \\
\hline
\end{tabular}

Fonte: Oliveira, Alyne. A partir de dados coletados em trabalho de campo de março a maio de 2005.

GRÁFICO A - Locais de pesquisa

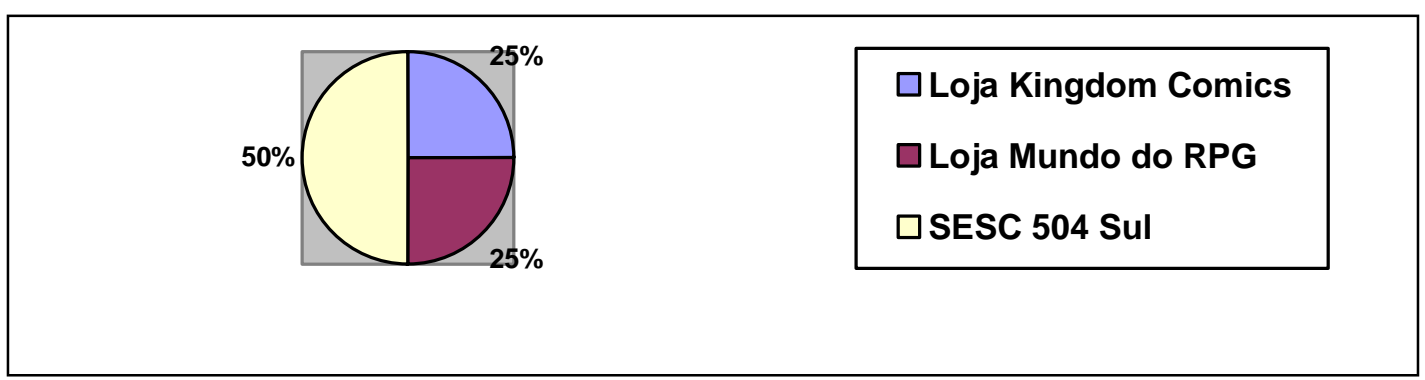

Fonte: Oliveira, Alyne. A partir de dados coletados em trabalho de campo de março a maio de 2005.

Comentários: Observa-se nestes dados que o local mais freqüentado pelos praticantes é SESC da 504 sul com 50\% dos entrevistados. As lojas Kingdom Comics e Mundo do RPG ficaram com a mesma percentagem, $25 \%$.

\section{REFERENCIAL TEÓRICO}

\subsection{As bases históricas do lazer}

As opções no que diz respeito às atividades de lazer, talvez nunca tenham sido tão grandes e tão estruturadas como é hoje em dia. A ampliação do tempo livre tem propiciado cada vez mais o desenvolvimento de atividades relacionadas com o entretenimento. A importância dada às atividades hedônicas sempre existiu na história da humanidade, principalmente entre as civilizações antigas, porém o desejo hedonista vem se demonstrando de forma muito intensa nos dias de hoje. Como afirma Camargo (1998:9) "A diversão, o lazer, o entretenimento - ideais de vida de algumas civilizações antigas, como a grega, a romana e, de certa forma, a chinesa - foram esquecidos. Mas, nesse final de milênio, voltaram com força total, assustando algumas autoridades, trazendo preocupações novas, muito novas mesmo..." Vendo toda essa força cabem duas perguntas: o que realmente é o lazer? E qual a sua função? 
Dois termos que se confundem muito facilmente são o lazer e o ócio, porém o que se pode destacar de mais significativo para este trabalho é a idéia de tempo livre e o ideal de lazer que se apresenta de forma utópica como um sonho que deveria ser real para a sociedade, mas que para muitos não chega nem a ser uma possibilidade isso porque, hoje, inegavelmente, há uma relação tênue entre lazer, trabalho e as conquistas trabalhistas, o primeiro está diretamente ligado ao segundo, e quase sempre existe em razão deste.

Quanto ao que é o lazer, há uma grande dificuldade, por parte de estudiosos, em se determinar um conceito exato deste. E esta se torna maior devido às próprias características peculiares inseridas no termo e devido principalmente à sua subjetividade. Ao que se sabe, o lazer é sempre praticado durante o tempo livre, com atividades desligadas das obrigações habituais, e isto é comum à maioria dos estudiosos do tema. Outro aspecto é o caráter de que o mesmo tem de ser único a cada indivíduo que pratica uma atividade de lazer, pois o mesmo se apresenta a cada um das mais variadas maneiras e o que para certas pessoas é muito prazeroso e divertido para outras podem não ter a menor graça.

Na tentativa de clarear um pouco esta idéia é possível captar na raiz da palavra algumas informações: o termo lazer vem do latim, licere, e significa "ser licito”. Tempo de que se pode livremente dispor, uma vez cumprido os afazeres habituais. Atividade praticada nesse tempo, divertimento, entretenimento, distração, recreio. Sinônimo de ócio, descanso, folga, vagar. Implicando desocupação, senso de prazer e da volúpia. Ferreira (1986: 1016)

Outros estudiosos e profissionais da área apresentam infinitas definições para o termo, estes nunca chegaram a um consenso, sendo, porém, possível dividi-los em duas linhas de pensamento: uma que o enfatiza como um estilo de vida e outra que dá maior consideração a questão do tempo situando-o como aquele liberado do tempo de trabalho. Para esta pesquisa os dois pontos são relevantes, uma vez que o perfil do jogador deverá apresentar também a maneira em que o mesmo encara o seu lazer e o tempo em que dispõem para praticá-lo, ou seja, há uma preocupação aqui de entender o RPG como lazer sobre dois aspectos - tempo e atitude. Marcelino (1990:29)

Entre tantas definições sobre o lazer destaca-se a de Bramante (1998): 
"O lazer se traduz por uma dimensão privilegiada da expressão humana dentro de um tempo conquistado, materializada através de uma experiência pessoal criativa, de prazer e que não se repete no tempo/espaço, cujo eixo principal é a ludicidade. Ela é enriquecida pelo seu potencial socializador e determinada, predominantemente, por uma grande motivação intrínseca e realizada dentro de um contexto marcado pela percepção de liberdade. É feita por amor, pode transcender a existência e, muitas vezes, chega a aproximar-se a um ato de fé. Sua vivência está relacionada diretamente às oportunidades de acesso aos bens culturais os quais são determinados, via de regra, por fatores sócio-politicos-econômico e influenciados por fatores ambientais.”

Talvez esta definição seja uma das mais abrangentes no que diz respeito ao significado de lazer, e mesmo que não seja, interessa muito a esta pesquisa, pelo fato de que o autor tentou englobar todos os aspectos físicos, psicológicos, ambientais, de ocupação de tempo e de espaço, de utilização de materiais, da própria expressão humana, do prazer que proporciona e de tantos outros campos que envolvem uma atividade de lazer. E por isso, enriquece este trabalho, pois entendeu-se que para os praticantes o RPG é uma atividade que aparentemente se dá da maneira acima retratada e que provavelmente envolve, se não todos, pelo menos grande parte dessas características para seus jogadores.

Desta maneira, através das definições citadas verifica-se que se trata do período de tempo livre de que se pode dispor para realizar, sem obrigação de tempo e lugar, qualquer atividade capaz de aliviar o estresse, dar prazer, e que esta é uma tentativa de fugir das tensões impostas pela vida cotidiana moderna. Essa é uma características que adveio com a sociedade industrial, fato é que o aproveitamento do tempo livre e a maneira como o mesmo foi visto e gozado durante a história do homem muito se diferencia do que representa hoje para o que vêm se denominando sociedade pós-industrial.

Nas sociedades primitivas e/ou agrárias as atividades lúdicas estavam intrinsecamente ligadas às rotinas de trabalho e de relações sociais, sendo que as festas e comemorações se davam em favor deste. As pessoas se juntavam para o trabalho, mas finalizava-os com bailes e cantorias. Ou seja, antigamente reuniam-se tanto para os 
trabalhos da agricultura, quanto para a manufatura doméstica, reuniam-se os vizinhos, agregando-se trabalho e festa.

Já na sociedade moderna o lazer se apresentou com outras funções, agora contrarias a de anteriormente, pois esta atividade passou a ter uma funcionalidade jamais existente. O lazer se tornou um meio ou maneira de compensar a rotina de trabalho, isto fica claro quando observado o comportamento do trabalhador que massacrado pelas obrigações e metas de trabalho e vendo que o lúdico, o prazer a contemplação foram banidos de sua rotina, se apegam a esperança de que chegue logo o tempo futuro das férias, dos feriados, dos fins de semana e até mesmo de expediente, Sant’ana (1994:37).

Está claro que desde os primórdios da humanidade, os homens tentam encontrar momentos lúdicos que sejam capazes de abrandar suas preocupações, tanto é que, de acordo com a evidência histórica é possível verificar que a civilização grega criou uma cultura do lazer e para o lazer, mesmo não tendo democratizado-a, afinal era uma sociedade escravocrata, onde todas as atividades relacionadas ao trabalho eram feitas por um exército de imigrantes, servos e escravos, que faziam o chamado "serviço sujo", ou seja, os trabalhos manuais, domésticos, nas minas, nos ateliês, etc.

Com a Revolução Industrial, no século XVIII, e ainda baseado na idéia de acumular bens, herança da reforma protestante, uma série de invenções e inovações técnicas modificaram as condições de produção nos diversos setores industriais, acarretando uma reestruturação na relação de trabalho e de atividades realizadas no tempo liberado. O trabalho passou a ser a única preocupação, com jornadas longas e cansativas, o que enriquecia àqueles preocupados com os lucros, conforme afirma Bacal (2003:63) “Assim como a finalidade era produzir muito por um custo mínimo, a jornada de trabalho era extensa. Ia de 12 horas por dia, atingido até 16 horas”. Neste contexto, era quase impossível se preocupar com o aproveitamento de tempo livre, ou melhor, disponível, uma vez que o mesmo praticamente não existia.

Sendo assim, o capitalismo criou a situação em que os trabalhadores não dispunham de tempo para dedicar-se à diversão e ao lazer. A vida do trabalhador dividiase em tempo de trabalho e tempo de não-trabalho, e esse tempo liberado serviria somente para o repouso. A situação era tão critica e hipócrita que Paul Lafargue (1842-1911), genro de Karl Marx (1818-1883), no manifesto O direito à preguiça, ridicularizou as reivindicações dos operários sobre o direito ao trabalho, em vez de lutarem diretamente 
pelo direito aos privilégios de lazer dos empregadores. Mesmo sem ser levado a serio à época, a obra de Lafargue anunciou como surgiria o lazer moderno. Camargo (1998:31)

Há de observar que a conquista por maior tempo livre desenrolou-se através dos anos. Até que, não sendo mais suficiente somente o tempo de descanso o ideal passou a ser que os trabalhadores conseguissem recuperar suas energias para manter o ritmo de produção. Camargo (1998:32) aponta como isso se desenvolveu:

\begin{abstract}
"Vejamos o processo. Primeiro lutou-se pela jornada de 8 horas e assim, surgiu um tempo diário de lazer. Em seguida, lutou-se pela jornada semanal de 40 horas e surgiu o repouso semanal remunerado; depois, pelo direito à pausa anual e surgiram as férias remuneradas; e, finalmente, pelo direito ao não-trabalho na velhice e surgiu a aposentadoria remunerada.”
\end{abstract}

Desta forma, o lazer passou a ser pago pelo capital resultante do trabalho, sendo ainda, previsto no resultado produtivo final. O progresso e a modernização das formas de produção industrial auxiliaram para o crescimento do tempo livre e do tempo de recreação. $\mathrm{E}$, é assim que a idéia de lazer e aproveitamento do tempo livre foi se modificando ao longo da história, e é assim, também, que se apresenta hoje: como produto do processo de industrialização.

Além do que, com capitalismo instaurou-se uma sedução pela materialidade. Submergiu-se num desejo de consumo jamais visto. Torna-se cada vez mais atrativa uma perspectiva de felicidade baseada na posse do material, na possibilidade de comprar seu prazer e na racionalidade dos processos da vida. A fantasia e o imaginário, não pertence mais apenas aos devaneios e a mente do sujeito, ela é transferida para bens palpáveis, para um símbolo, a relação deste com o mundo alienou-se de tal maneira, que no caso de um turista, por exemplo, não mais lhe basta ir a um lugar visitá-lo, é importante tirar fotos e comprar souvenires para que está experiência possa ser vivida outras vezes e esse local consumido novamente quantas vezes mais lhe interessar. Bacal (2003:26)

É o caso, também, do RPG que, de alguma maneira, representa esse bem material que supre a necessidade de consumir para se alcançar a felicidade e o prazer. Dito isto porque o mercado de produtos para esta prática tem cada vez mais crescido, ofertando ao jogador livros, revistas, suplementos, camisetas, miniaturas entre tantas outras 
possibilidades. Outro fato é que o praticante pode não mais apenas representar com a sua imaginação o personagem, mas agora existe a possibilidade de se caracterizar como este. Hoje se pode comprar uma fantasia e vesti-la para se sentir melhor, mais poderoso, enfim, há a opção de se comprar uma espécie de pacote que satisfaça seu prazer. Assim, diferente da sociedade agrária, onde se geravam as coisas e faziam com que elas acontecessem, na industrial é tudo empacotado, e oferecido já pronto.

Sem sombra de dúvida que a crescente industrialização e a diminuição da carga horária de trabalho resultou num acúmulo maior de tempo livre, e conseqüentemente, num maior tempo para o lazer. Contudo, isto gerou novas questões e problemas. Dumazedier (2000:20) entende que:

\begin{abstract}
“(...) O lazer apresenta-se como um elemento central da cultura vivida por milhões de trabalhadores, possui relações sutis e profundas com todos os grandes problemas oriundos do trabalho, da família e da política que, sob sua influência, passam a ser tratados em novos termos. Gostaríamos de provar que, em pleno século XX, não é mais possível elaborar teorias sobres as conseqüências neles determinadas pelo lazer."
\end{abstract}

Sendo o lazer uma preocupação de grande parte dos trabalhadores as atitudes e expectativas para com suas “atividades obrigatórias” passam a ser outras, pois, a relação do mesmo com o tempo de trabalho diz respeito a incessante busca por atividades que tragam prazer e diversão aos indivíduos. Porém, Dumazedier (2000:23) nos conta que “a estafa dos quadros profissionais, sociais e culturais torna difícil um verdadeiro descanso e que a atual duração do lazer não corresponde às crescentes necessidades de evasão”. Ainda assim os olhos do trabalhador começam a enxergar as coisas da seguinte maneira: diferentemente do ócio, o lazer é um direito conquistado com o esforço do seu trabalho e deve ser gozado não só por causa de desejo e prazer, o que talvez seja o mais evidente, mas também para aliviar o esforço físico e mental e impedir futuros problemas, inclusive de saúde, mesmo que tudo isso ocorra em tão pouco tempo e de forma não tão significativa e intensa, isso porque muitas vezes questões, como a financeira, não permitem o melhor aproveitamento deste tempo. 
Cabe neste momento abordar a seguinte questão: quem é este trabalhador? O trabalhador não é só aquele que possui remuneração, todos que desenvolvem ou praticam atividades obrigatórias no seu dia-a-dia, estão trabalhando, mesmo que não recebam uma remuneração por isso. É relevante aqui voltar-se às pesquisas realizadas para este trabalho, percebe-se que entre os praticantes do RPG, jogo que se tornou objeto desta exploração, há aqueles que realizam atividades remuneradas, contudo, sua grande maioria são de estudantes que mesmo não recebendo por isto praticam atividades obrigatórias no seu cotidiano, sendo assim considerados, ao menos para este estudo, trabalhadores, tendo portanto, de acordo com a teoria geral do lazer, já explorada anteriormente, direito a gozar seu tempo livre.

É assim, que se torna possível ver os vários motivos para crescimento de práticas de atividades de lazer, além da esfera romântica e poética apresentada no inicio deste texto, o lazer segue uma perspectiva funcional, afinal, de acordo com aquela linha de pensamento que enfatiza o tempo e levando em consideração uma visão mais mercadológica e capitalista do mundo, a liberação do tempo para o homem tem caráter muito maior de descanso e recuperação da força de trabalho. Dumazedier (2000:23) nos conta: "O trabalho industrial, sendo de execução mais fragmentária e organizada e ainda mais rápido do que no século XIX, implica uma fadiga maior para os nervos e por isso impõe, com maior força, na consciência da maioria dos trabalhadores, a necessidade de repouso e evasão." Outro aspecto funcional atribuído ao lazer refere-se ao que outra linha de pensamento defende: que esta atividade está ligada à idéia de atitude e a um de estilo de vida.

Contudo não interessa neste momento separar linhas de raciocínio, mas sim compreender o valor e a função das atividades de lazer sobre todos os seus aspectos. Muitos autores defendem o lazer tendo como principal função a beleza, a utopia e romantismo, outros dão a ele o poder de moralizar e construir o individuo que o pratica. Atribui-lhe, ainda, o fator compensatório, onde a prática de atividades de lazer compensaria a insatisfação e a alienação do trabalho. Por fim uma classificação mas utilitarista dando ao lazer à função de recuperação da força de trabalho. Assim todas essas abordagens conferem ao lazer o poder de 'manutenção da ordem', 'da paz social' e de válvula de escape da agressividade, contribuindo para reduzir as trangressões de ordem social. Marcelino (1990:38) 
Por se apresentar como revigorador da força de trabalho e também por perceber o seu potencial, em várias outras esferas, sobretudo a econômica, é que vem crescendo vertiginosamente a importância dada às atividades de lazer. De alguma maneira o preconceito que pesa sobre o ócio está ficando de lado e cresce a importância do tempo livre, isto porque este é um dos setores que mais dinamizam o mercado, até como foco gerador de novas funções trabalhistas. Conforme Camargo (1998:137) menciona: “O setor econômico do lazer e do entretenimento, que não para de inovar, trouxe à luz a importância de um profissional - até então raro no mercado - aqui mencionado sob a denominação genérica de animador cultural”.

Seguindo a lógica do capitalismo, várias organizações empresariais junto a estudiosos perceberam a capacidade de recomposição e compensação dos desgastes advindos do trabalho nas atividades de lazer, utilizando-as estrategicamente e ainda como outras possibilidades de manter ou elevar a lucratividade, tomando como exemplo os clubes e associações que várias empresas mantêm no intuito de satisfazer as necessidades de seus empregados tentando garantir assim o bom desempenho do mesmo.

Surge ainda, o terceiro setor, com novidades em ofertas, não mais só de aquisição de produtos, mas oferecendo serviços e espaços para se divertir e gastar aquilo que é conquistado com o fruto do trabalho. Este novo leque de opções de divertimento possibilitou uma nova forma de auferir lucros e usufruir os já alcançados, agora é possível realizar atividades prazerosas de curta duração, como passeios, pequenas viagens, e mais recentemente, atividades lúdicas, muitas vezes de pequena duração, como é o caso do Role Playing Game, geralmente praticado nos fins de semana.

Para reforçar a importância dada as atividades hedônicas, pode-se atentar ao fato de que o RPG surgiu nos Estados Unidos, e é influenciado por elementos da cultura japonesa, países que costumam viver dedicados ao trabalho e possuem uma cultura imbuída da "história do fazer", claro que não cabe aqui aprofundar esta questão, mas ao que parece criações como este jogo, entre tantos os outros criados pelos mesmos, surge com a necessidade de compensação dos seus esforços na maior parte dedicados ao lucro. É a velha história de que o homem busca experiências que os equilibrem, ou seja, realizações e prazer.

Portanto, realmente é de grande notabilidade a crescente demanda de profissionais e educadores que se interessam pelas atividades ligadas ao entretenimento. 
As instituições de ensino, as organizações governamentais e as grandes empresas do ramo da diversão procuram cada vez mais encontrar formas de desenvolver e aumentar o interesse na sociedade pelo lazer. Essas atividades cada vez mais se destacam, nas mais diversas áreas e dos mais variados tipos, como já foi citado o exemplo do Role Playing Game. Já há algum tempo esta atividade vem se sobressaindo como opção de lazer para os habitantes de Brasília/DF. Como verificado na pesquisa de campo, os praticantes da atividade mencionada acima, são jovens ou pessoas no inicio de sua fase adulta, em sua maioria estudantes, que possuem um tempo significativo para a realização de atividades do campo lúdico e prazeroso que envolve o tão mencionado lazer.

\subsection{Questão do tempo livre dos jovens}

Como nesta pesquisa foi apresentado uma evolução da idéia de lazer por todo história do homem, ou pelo menos no período mais significativo para o tema, é interessante colocar um dado à respeito das civilizações primitivas agrárias para destacar como era encarado o tempo livre das famílias e fazer compreender como modificou o olhar e as atitudes do homem, da própria família e do jovem com relação ao lazer.

Segundo Bacal (2003:34): “O trânsito das atividades obrigatórias, isto é, necessárias à sobrevivência (urgências vitais), para os momentos de lazer processava-se de forma natural.” Portanto, não há uma separação clara entre tempo livre e tempo de trabalho, entre o espaço de descanso, ou seja, a casa, e o espaço de trabalho, visto que essas idéias envolviam-se de tal forma que uma estava ligada a outra, cada uma existindo em função da outra.

Além da ausência de distinção entre os períodos dedicados ao trabalho e ao descanso, pode-se constatar, de acordo com pesquisas realizadas, que não só a maneira como eram encaradas as atividades obrigatórias, mas as relações sociais também eram diferentes. A colheita, os trabalhos manuais e de casa, as festas de comemorações e todas as outras atividades do dia-a-dia eram compartilhadas por todos os membros da família, inclusive permitia ou até mesmo exigia a presença do jovem.

O jovem participava ativamente nestas atividades familiares e desempenhavam papel importante na sociedade, conforme Adamo (1987:17) explica: 


\begin{abstract}
"Numa visão histórica, verifica-se que o processo educativo como um todo tem a finalidade de inserir o individuo à sociedade em que vive. Em tribos primitivas, a educação fazia-se através da própria relação entres seus componentes e da transmissão direta pela vivência em comum dos conhecimentos dessa sociedade; o saber é transmitido de geração em geração de forma que todos participam indiscriminadamente desse processo”.
\end{abstract}

Diferente do que acontecia na antiguidade, o mundo moderno, ou seja, a sociedade capitalista pós-industrial, conseguiu determinar claramente o tempo em que as pessoas dispõem para dedicar-se ao lazer e o tempo em que devem trabalhar. Criou-se uma estrutura de vida onde a momentos marcados e contados no relógio para se fazer cada coisa. O modo de produção industrial, mecânico e metódico, impõe uma dedicação exclusiva, compulsória e cansativa. Com isto, há uma necessidade cada vez maior de se praticar atividades que aliviem a tensão das obrigações cotidianas. Embora, possa se imaginar que na antiguidade, tais obrigações também impunham uma certa tensão, é possível conceber uma idéia de que, apesar do árduo esforço físico, antigamente o modo de produção não causasse tantos desgastes como desordem e desequilíbrios psicossomáticos quanto causa atualmente.

Foi visto que o mundo moderno diferencia bem o que é o tempo de trabalho do que é o tempo de não trabalho, mas, além disso, ele diferencia também quem é o sujeito que pode trabalhar e aquele que não pode. Antigamente todos tinham o seu papel na colheita ou nos afazeres de casa e tudo era feito em família, existia uma certa hierarquia dentro dela.

Hoje as relações e deveres são muito bem definidas pelo sistema produtivo que estratificado em classes influência as funções/ papéis no cenário do trabalho e na sociedade e conseqüentemente no lazer. Os chefes de família são os responsáveis por sustentar e garantir todos os direitos de todos os seus dependentes, e entre eles o direito ao lazer, mesmo, sendo, contudo, esta preocupação cada vez mais em oferecer-lhes atividades, inclusive as recreativas, que visem sempre a educação de seus filhos para a vida adulta. Conforme Adamo (1987:18) explica: 


\begin{abstract}
"Na nossa sociedade o jovem precisa crescer para ser 'alguém'; toda a sua educação está voltada para o futuro, para isso desde cedo adquire conceitos geralmente desvinculados da sua realidade, mas que visam o seu encaixe no mercado de trabalho. Aprende, também, a competir; é testado de múltiplas formas; na escola enfrenta 'vestibulinhos', 'vestibulares', necessita ter uma profissão que o torne integrado ao mundo adulto.”
\end{abstract}

Isto mostra que a dedicação maior que os jovens têm em todo o seu tempo é para os estudos e que depois disso há uma liberação do tempo para outras atividades não obrigatórias, ou seja, para o lazer e o ócio. Cabe assim, a seguinte pergunta: como é aproveitado este tempo livre? Seria para prática de atividades de lazer? Ou seriam dedicadas às atividades que preencham seus currículos? A respeito da produtividade do tempo livre dos jovens Zavala (2004:) nos conta que:

“(...) conforme pesquisa realizada a partir de
entrevistas com 500 jovens ( 12 a 19 anos) das
mais diferentes classes sociais, $60 \%$ deles
passam o dia em casa, sozinhos. Quando
questionados se gastavam três ou mais horas
por semana fazendo tarefas escolares ou
estudando música, teatro ou qualquer atividade
artística, apenas $21 \%$ respondeu
afirmativamente.”

O trecho do autor citado acima apresenta como preocupação central em tornar mais produtivo o tempo liberado do jovem, tanto é que se nota claramente a necessidade que a grande maioria dos jovens possui de obter algo que consiga preencher seu tempo livre, ou seja, o tempo em que não estão na escola ou nas obrigações, que geralmente são de âmbito educacional.

Muitos pais e até mesmo os jovens, influenciados pela cultura moderna da produtividade acabam acreditando que o tempo livre deva ser preenchido por atividades intelectuais e/ou educativas que preencham seus currículos de forma a serem aptos e competitivos na sociedade. Contudo se esquecem ou ainda não se atentaram às propriedades não só educativas, mas também formadoras de caráter social, atentando-se aqui ao fato de que é no tempo de ócio que a evolução de muitas técnicas aconteceram, 
visto a sociedade dos gregos antigos, que quando estavam livres dos afazeres observavam os escravos (trabalhadores), na sua lida e através da atitude reflexiva percebiam novas possibilidades de melhorar aqueles trabalhos e produzir mais e melhor.

Além disso Camargo (1998:71) trata essa situação da seguinte forma:

\begin{abstract}
"O lazer é um modelo cultural de prática social que interfere no desenvolvimento pessoal e social dos indivíduos. Essa é a chamada educação informal, numa sociedade que, não apenas através da escola ou da família, mas também dos seus pontos de encontros, das informações difusas de tevê, jornais, out-doors, cinema, bate-papos, se converte numa sociedade educativa. Esse desenvolvimento será positivo ou negativo? Esses modelos lúdicos auxiliam as pessoas a suportar os limites da expressão pessoal existentes no trabalho, na família ou as desajudam?”
\end{abstract}

O problema aqui estabelecido situa-se em se saber de que forma e como o tempo livre de que os indivíduos dispõem para realizar atividades pessoais auxiliará a resolver questões de suas vidas pessoais e as relações sociais no dia-a-dia. Esta preocupação é claramente apontada, novamente, por Camargo (1998:76):

"Uma pesquisa internacional, realizada em 1979 e 1980, pelo Instituto Galup, em diferentes países do Ocidente e do Oriente, mostrou que, nos países ocidentais, a maioria dos jovens confia no tempo livre, mais do que no tempo de trabalho, como campo de realização pessoal. Ou seja, ao ingressar no mercado de trabalho, os jovens, hoje, sabem de antemão que o emprego a eles reservado dificilmente será uma oportunidade de criatividade, de enriquecimento da personalidade. Esta realização deverá ser buscada, assim, nas ações cotidianas que o rendimento do trabalho poderá proporcionar como um filme, uma peça de teatro, uma viagem, um curso.”

O trecho acima nos mostra que o jovem já está despertando para a importância do lazer em suas vidas, até porque, e isto é importante frisar, mesmo que o jovem não 
trabalhe em empresas, pode-se perceber que a rotina escolar e os padrões educacionais exigem dos estudantes, em termos de esforço para se alcançar metas e objetivos, tanto quanto ou mais que o mercado capitalista do trabalhador.

Desta maneira, fugindo das idéias e estruturas de vida capitalista, o mesmo está buscando o prazer em atividades que permitam a expressão da suas contenções diárias, como no caso do RPG, ao que parece é através do jogo e de suas propriedades lúdicas que eles tentam romper com as fronteiras e limitações do mecanicismo e da ordem. Porém, mesmo com essas opções, denota-se claramente que os jovens estão cada vez mais certos de que a sociedade na qual vivem e que os trabalhos a qual serão submetidos estão bem distantes de proporcionar uma plena satisfação pessoal. De acordo com Camargo (1998:33):

\footnotetext{
"Vivemos uma civilização do tempo livre, em que este já é quase igual e às vezes maior do que o tempo de trabalho. Mas ainda estamos longe de uma civilização do lazer, em que as pessoas saibam ocupar esse tempo livre com atividades que efetivamente lhes divirtam e contribuam para seu desenvolvimento pessoal.”
}

Certamente, a preocupação com o hedônico torna-se paulatinamente uma das maiores questões da sociedade, mas pelo momento todos não param de pensar no tempo de evadir de suas obrigações. A sociedade tem opções de pacotes que são ofertados pelo sistema para manter seu tempo livre ocupado com atividades que as divirtam e distraiam, mas não que necessariamente contribuam para um desenvolvimento intelectual, e isso faz com que o ideal de se tornar uma sociedade do lazer fique cada vez mais longe de ser alcançado. Não que o ideal seja viver apenas do e para o lazer, afinal essa seria uma outra polarização “doentia”, mas a busca seria por uma sociedade onde o trabalho também seria um realizador, ou seja, fugir dessa época onde há uma obsessão pelo trabalho que distância o sujeito do lúdico e ajudá-lo à reaprender o brincar.

Exemplo disto, seria as propriedades do lazer nas atividades escolares obrigatórias. A editora Akritó realizou um trabalho nas escolas do Rio de Janeiro e Niterói, que buscou tornar o RPG um jogo conhecido, tentando diminui o preconceito relacionado a ele, com isso, em 1999, Carlos Klimick e Flavio Andrade, trabalharam como 
professores em duas escolas do Rio de Janeiro, 'mestrando' (termo comumente utilizado para designar a prática de conduzir os jogos) para turmas de $7^{a}$ série temas históricos, como a decadência da idade média e a renascença. Andrade (1999:49)

Contudo, pode-se observar, que de certa forma, não faltam opções para tentar alcançar este objetivo. A diversidade de entretenimento que o mercado oferece é enorme, teatro, cinema, livros e espetáculos ocorrem diariamente em todos os centros urbanos. Dentro deste universo de atividades, ao que parece, o Role Playing Game tem se mostrado uma opção de divertimento e recreação, desempenhando, para seus praticantes, as funções compensatórias do lazer. Por isso, dando seguimento, e com objetivo de especificar o panorama em que se encontra atualmente o RPG, faz-se necessário abordar o histórico deste jogo, como ele se desenvolveu até hoje e as opiniões de algumas pessoas que trabalham profissionalmente com o jogo.

\subsection{Conhecendo o RPG}

O Role Playing Game - Jogo de Interpretação de Personagem (RPG) é um jogo onde um narrador conduz uma história e jogadores têm a oportunidade de interpretar personagens "quase que teatrais" que protagonizam o enredo desenvolvido, de alguma maneira, por eles mesmos, pois o desenrolar da trama dependerá quase que totalmente de suas decisões e atitudes.

O jogo é muito parecido com conduzir personagens de jogos eletrônicos, os famosos vídeo-games, ou como jogos infantis de "faz de conta”. Afinal, cada indivíduo representa um papel criado, geralmente, por ele mesmo. A revista especializada em RPG Dragão Brasil nos traz algumas definições, de acordo com o autor Klimick (2000:45)

“(...) É uma forma diferente contar história... Em vez de uma historia contada para você, ela será contada com você (...) No RPG os participantes (ou jogadores) controlam os personagens da história, e decidem suas ações. Os personagens dos jogadores são os astros, os protagonistas da história a ser contadas. Assim como um escritor ou roteirista pode imaginar qualquer herói, vilão ou criatura, os 
personagens jogadores de RPG podem ser qualquer coisa - mas, em geral, serão coerentes com a história a ser contada(...)”

O jogo surgiu em 1974, teoricamente, criado por Gary Gygax e Dave Arneson quando lançaram o primeiro livro de RPG do mundo: “Dungeos e Dragons” (D\&D), com narrações, histórias e regras fictícias, de um mundo também fictício, de fantasia medieval. O que se sabe é que esta atividade surgiu como derivado dos populares wargames, ou seja, jogos de estratégia e simulação de batalhas históricas ou fictícias muito famosos nos Estados Unidos da América - EUA.

A sua semelhança com literaturas como "O Senhor dos Anéis” e "O Hobbit”, ambos de J. R. R. Tolkien, não é mera coincidência. Nos conta Klimick (2000:46): “Como ambos gostavam muito da literatura de Tolkien - autor de "O Senhor dos Anéis - , o jogo D\&D é repleto de magos, cavaleiros e dragões. Esse gênero, a fantasia medieval, seria para sempre o mais popular entre os RPGistas.”

Com o tempo surgiram novos títulos e outros cenários, novos autores, e cada vez mais jogadores, e principalmente novas ambientações, tais como: terror, ficção cientifica, faroeste, piratas, espionagem, fatos históricos, futurísticos e outros mais.

O RPG chegou no Brasil em meados da década de 80 e era mais popular entre os universitários, talvez pelo fato de não existirem títulos em português no país nesta época, como muitos livros que ainda hoje não foram traduzidos. Um fato curioso é que por serem os livros importados e, claro, muito caros, os grupos de jogadores costumavam se organizar fazendo as famosas “vaquinhas” para adquirir as publicações estrangeiras, fazendo cópias para cada membro. Como afirma "El Cid” (2004), editor do web site “A Arca”: "O mercado de RPG no Brasil teve início com a chamada "geração xerox", apelido criado pelos próprios fãs para designar os grupos de jogadores que, por não terem acesso aos livros americanos, se viravam da melhor forma possível, tirando infinitas cópias dos volumes importados.” Esta prática chamou a atenção da Devir Livraria, que no começo dos anos 90 passa a importar alguns títulos para o Brasil. Logo em seguida surge um módulo básico nacional de GURPS (Generic Universal Role Play System - Sistema de RPG Genérico), criado pela Steve Jackson Games, famosa companhia de jogos dos EUA, este sistema é considerado um “RPG Universal” pois aceita qualquer gênero e/ou cenário, 
este foi um fato que contribuiu para popularizar e gerar um número maior de jogadores no país.

Não tardou muito e logo este jogo foi publicado em outras línguas, no caso do português, de acordo com Klimick (2000:46), foi em 83 que traduziu-se uma antiga versão de D\&D em Portugal. No caso do Brasil, o primeiro jogo publicado foi RPG Aventuras Fantásticas - uma introdução aos Role Playing Games, isto aconteceu no início dos anos 90. Em 1991, surge "Tagmar” o primeiro e legítimo RPG brasileiro, produzido por Ygor Morais, Leonardo Nahoum, Marcelo Rodrigues e Julio Cezar Jr., publicada pela GSA, editora dos autores. “O Desafio dos Bandeirantes” foi o segundo título escrito por brasileiros, onde, embora não seja completamente fiel a história do país, a sociedade e o folclore do Brasil do Século XII está reproduzido na integra.

As obras brasileiras citadas acima sofreram muitas criticas, pois alguns defendiam a idéia que estas publicações eram apenas cópias de edições estrangeiras. Apesar de enfrentar questões como estas o RPG se apresentou como opção de lazer para os brasileiros, principalmente aos jovens, e conseguiu se expandir no mercado. Novamente “El Cid”(2004) nos explica:

"Tanto "Tagmar" quanto "Desafio dos
Bandeirantes" enfrentaram uma série de
problemas nos anos que se seguiram. Enquanto
"Tagmar" era considerado mera cópia do
AD\&D e outros sistemas de fantasia medieval,
"Desafio..." foi acusado, segundo contam seus
autores (Carlos Klimick, Flávio Andrade e
Luiz Eduardo Ricon), de ser "cópia descarada
do GURPS". Mesmo assim, o mercado cresceu
até 1994, quando teve uma explosão com a
entrada das editoras Abril e Ediouro (que
popularizou os chamados 'livros-jogo', no qual
um único jogador vai escolhendo suas opções e
decidindo os rumos da história, sem a
necessidade de um mestre para guiar a
narrativa).”

Em 1995 e 1996 o índice de crescimento do jogo no mercado brasileiro retraiu largamente, quando as editoras Abril, Ediouro e GSA retiraram-se do segmento. Porém, em 1997 editoras como a Devir, Akritó e Daemon dão nova vida e esperança de sobrevivência aos RPGs. Assim o jogo tem se tornado cada vez mais popular, conhecido e 
praticado pelos jovens e adultos brasileiros. Alguns dados revelam que o fã clube oficial da editora White Wolf, o The Camarilla, possui cerca 6.000 membros inscritos em 16 países, dentre eles, Brasil, Estados Unidos, Canadá, etc. Ribeiro (2003:10)

Quanto ao nível de crescimento e expansão deste jogo, existem várias e divergentes opiniões. Jogadores, especialistas, pesquisadores, profissionais, curiosos e amantes desta atividade fazem constantes afirmações sobre esta questão. Enquanto alguns defendem um crescimento espantoso desta prática, como é o caso de Guilherme Moreno, do web site Spellbrasil, que afirma: "Existe muito trabalho de divulgação e conscientização a ser feito para que o RPG realmente pegue no Brasil.” Moreno acha que a popularização dos videogames voltados para a temática dos RPGs e o lançamento dos filmes baseados na ambientação de "Dungeons \& Dragons" e na trilogia de "O Senhor dos Anéis" podem ser propulsores de uma explosão futura. "O grande momento está próximo", diz, ansioso.

Temos profissionais da área que descordam quase que completamente das afirmações acima. João Mauro Trevisan, editor da revista Dragão Brasil, a maior revista do gênero no Brasil, em entrevista para o web site “A Arca” declarou:

\footnotetext{
"Vivemos num país onde o povo tem preguiça de ler jornal e os quadrinhos infantis da Mônica são lidos por gente de mais de 30 anos. O RPG não combina com o perfil cultural do brasileiro mediano. O mercado de RPG não é constante. Sempre tem gente parando de jogar, parando de comprar. Quando comecei com 15 anos, jogava todos os finais de semana. Hoje tenho 25 , outras preocupações, outros meios de diversão, sem querer você acaba diminuindo o ritmo".
}

Dentro deste contexto de conceitos diversos é que esta pesquisa se realiza. Não é o intuito de avaliar o crescimento mercadológico desta atividade e sim conhecer o jogador de Brasília/DF para compreender a representação e importância do jogo como uma forma de recreação para este público. É importante ainda entrar no âmbito das relações sociais e das relações pessoais que permeiam o jogo.

\subsection{A “viagem” do RPG.}


Por todas as características já conhecidas que envolvem o RPG, sabe-se que o mesmo se encaixa na classificação de atividades recreativas. Utilizando-se do Dicionário da Língua Portuguesa da Editora Barsa Planeta Internacional Ltda (2004:880) encontra-se o seguinte significado para Recreação: “Divertimento, prazer. Coisa ou coisas que recreiam. Lugar próprio para recrear-se”, ou seja, evasivas, desculpas, pretextos, escapatórias para algo onde você quiser, para uma realidade ou fantasia que faz quebrar uma lógica e equilibrar as necessidades humanas.

Assim o conceito aparece mantendo uma relação tênue com prazer e divertimento. Guerra (1996:17), aponta que “A recreação compreende todas as atividades espontâneas, prazeirosas e criadoras, que o individuo busca para melhor ocupar seu tempo livre.” Este termo, recreação, está imbuído da idéia de reproduzir, de criar alguma coisa, desde que seja de forma espontânea e criativa, conduzindo, e novamente aqui ele se apresenta, ao prazer, ou melhor, à satisfação do indivíduo que o pratica.

Por tudo que já foi estudado, e será apresentado ao longo deste trabalho, o RPG, agrega as características citadas acima, afinal ele reproduz a realidade onde o jogador é capaz de se reencontrar com suas fantasias e desejos, é capaz de resgatar o patamar ilusório de suas histórias de infância e é capaz de envolver a sua vida cotidiana e de projetar o seu ego e sua imaginação imitando ou criando novos universos. Cultivando ainda o hedônico, maneira de relaxar e fugir das obrigações, o que seria um reencontro, com o direito de aproveitar a vida.

Estudiosos revelam a influência e valor deste jogo para seus praticantes. Rodrigues (2004:154) aponta que: “(...) O RPG existe e se espalha como coqueluche por que existe uma necessidade, cada vez maior de retorno à ficção.” Necessidade esta, que está imbuída no homem desde de sempre, porém que vem se destacando de tal forma nesta sociedade obcecada pelo trabalho e carente de prazer.

Acontece que atividades, como o RPG, cumprem a função que atividades recreativas e/ ou de lazer têm de despertar o lúdico, o lado brincante daquele que o prática, apresentando-se como uma catarse. Yázigi (2001: 257) conta que: “Freud relacionou a fantasia com os jogos infantis, ambos originários das mesmas motivações. Mas para ele a função destes últimos, além de repetir o passado (controle de traumas) serviria antes para alívios emocionais e planejamento de adaptações do futuro.” 
Ou seja, diante de uma vida altamente estressante precisa-se de algum tipo de válvula de escape, de uma possibilidade de criar, recriar, contar, se reencontrar, imaginar, projetar, fantasiar e até mesmo imitar. Yázigi (2001: 257) continua dizendo que “A fantasia pode tornar-se realidade, pois sem a capacidade de sonhar o mundo seria sempre o mesmo.” E desta maneira, o espaço-tempo do jogo serviria para romper com a lógica estabelecida pela sociedade mantendo assim o equilíbrio do individuo.

Entre autores e pesquisadores do lazer sempre existirão várias teorias, contudo o que é interessante neste momento, pode ser explicado por Waichman (1997:125): “A maior parte de tais definições está centrada no jogo e na diversão, que, como já vimos, implicam sempre uma compensação (contrafunção) das atividades 'sérias' e rotineiras; o componente básico é a alegria, que, na realidade, termina quando acaba a atividade organizada.”

Esta explicação acima tenta reunir os principais aspectos que envolvem a recreação, não que ela esteja completamente correta, mas consegue abranger um ponto de vista que chama a atenção para o objetivo e a motivação da recreação, que é divertirse, descansar, fugir da rotina cansativa do que o autor chamou de "atividades sérias". Realmente a palavra recreação está fortemente ligada ao conceito de entretenimento, ou seja, atividades que produzam prazer sem requerer imprescindivelmente compromisso. Waichman (1997: 126)

Mesmo que muitas vezes haja esse compromisso do ator que realizará as atividades, como no caso do RPG, onde é essencial reunir informações a respeito do assunto, é possível notar que os grupos existentes, os quais possuem algum nível de organização, são compostos por rpgistas que assumiram um compromisso com seu grupo e com seu desejo de jogar, mas isto não os obriga a esta junto à estrutura a qual pertencem, e mesmo tendo, geralmente, datas e horários pré-definidos para seus encontros, conseguem de alguma maneira manter suas escolhas e a espontaneidade inicial.

Além disso, o jogo, a brincadeira, é um constructo da hora em que ela acontece, geralmente possui os elementos do imprevisível e do improvisar, como no caso do RPG, que mesmo sendo conduzido por um mestre/narrador, requer a habilidade de decisão e raciocínio rápido para solucionar questões não previstas, ou não conhecidas, pelos praticantes. Outro detalhe importante, é que, quem esta praticando qualquer jogo, sabe que 
esta brincando e que aquilo é ilusório, que vai acabar e que talvez até exista, mas em um outro campo, que aqui não se cabe tratar, caso contrário, eles teriam rompido com a realidade e viveriam uma esquizofrenia.

Acontece que, na maioria das vezes, o contexto em que está inserido a recreação supõe uma estrutura organizada e estruturada dentro de um tempo livre, na qual promovem-se jogos, técnicas expressivas, fazem-se acampamentos, reuniões, no sentido de juntar os indivíduos, tudo conforme o que se vê nas escolas e instituições voltadas para esse tipo de atividade, vide o exemplo das colônias de férias, dos escoteiros, creches e campings. Porém, uma obrigação imposta em se cumprir estas atividades, de acordo com alguns autores, descaracterizaria as atividades recreativas, e ao que parece o praticante de RPG tenta manter essa voluntariedade que os fizeram jogar.

É por isso, que quando se fala em recreação, logo remete-se aos tempos de escola, e principalmente aqui no Brasil este termo é fortemente associado à esta idéia, Gaelzer (1979:25) afirma: “A evolução histórica da Recreação acompanha o desenvolvimento da Psicologia, Pedagogia e da Educação.” A autora ainda cita que a recreação surgiu primeiramente associada à atividade infantil e, só mais tarde, se estendeu à vida do adulto, inclusive pode-se ressaltar que mesmo com a mudança deste ângulo de visão, onde as atividades recreativas passam a ser também direito dos adultos, ainda não foi possível se desvincular do preconceito de que, muitas vezes, aqueles mais crescidos que cometem essa ousadia são pessoas que nada tem a fazer de mais importante.

Entretanto, ao que se sabe, o jogo faz parte da vida do homem desde o inicio da história da civilização. O conceito de "jogo" discutido por Huizinga, afirma que a essência do jogo e sua característica primordial residem em sua capacidade de fascinação e divertimento. E para ele, o jogo é uma categoria absolutamente primária da vida, tão essencial quanto o raciocínio (homo sapiens) e a fabricação de objetos (homo faber), e conseqüentemente a denominação Homo Ludens, o ser brincante, está na base do surgimento e desenvolvimento da civilização. O jogo é uma atividade ou ocupação voluntária, exercida dentro de certos e determinados limites de tempo e de espaço, segundo regras livremente consentidas, mas absolutamente "necessárias”, dotado de um 
fim em si mesmo, acompanhado de um sentimento de tensão e de alegria e de uma consciência de ser diferente da "vida quotidiana". (Huizinga, 1980: 33)

É bom se atentar ao fato de que regras e limites devam existir, afinal, Yázigi (2001: 257) afirma que "O fantasiar é um ato no qual o fantasista está consciente de pertencer à imaginação. $\mathrm{O}$ que o fantasiador faz é dirigir um script senão pertenceria ao domínio da alucinação ou da ilusão.” Tomando o objeto de estudo da presente pesquisa, o RPG, é certo que o respeito às regras, a interação entre os jogadores e a dedicação são condições essenciais para a manutenção do jogo num mundo próprio e à parte da vida real.

De qualquer maneira, fica claro como o jogo faz-se necessário na vida e no cotidiano do homem que pensa e do homem que trabalha e produz, sendo tão importante quanto qualquer outro aspecto, afinal o mesmo tem como papel principal aliviar a tensão do dia-a-dia e acrescentar diversão para o indivíduo que o pratica. Além disso, Person (1997:251) mostra a importância do brincar, do imaginar:

\begin{abstract}
“A fantasia culturalmente organizada não nos atinge apenas passivamente, por meio de nossas famílias e de mitos culturais gerais, mas também por nossa ativa exploração de materiais culturais. Cada um de nós processa a matéria- prima cultural para ver o que pode ser emendado para o script de nossos desejos e necessidades e de nossas fantasias subconscientes e inconscientes.”
\end{abstract}

O jogo, o lúdico, o imaginar, o fantasiar, determinaria o não levar a serio, contudo para os envolvidos demanda-se seriedade, no caso dos jogadores, em especial do RPG, isso se apresenta no respeito às regras e na característica essencial de absorvê-las. E mesmo sendo uma atividade voluntária, torna-se uma necessidade à medida que provoca prazer, e que torna a condição do homem mais humana.

O jogo é uma fantasia misturada com a realidade, no RPG, você pode ser o que quiser, representar qualquer papel. É evasão, fuga, válvula de escape, para uma esfera temporária de atividade com orientação própria. Rodrigues (2004:43) Reunir-se em busca destes é o que, aparentemente, rpgistas costumam fazer, e a reunião de grupos que tenha como objetivo principal o lúdico, caracteriza-os como uma Tribo Urbana. É importante tentar entender as motivações que levam a esta prática, guiada pelas categorias do lúdico, 
discutidas por Camargo, citando Caillois (1998:34): aventura, competição, vertigem e fantasia.

\subsection{O Lúdico e o RPG}

Antes de falar das categorias do lúdico, que serão tratadas aqui, com base nas teorias do sociólogo francês Roger Caillois, é importante entender o que significa este termo. De acordo com o Dicionário da Língua Portuguesa da editora Barsa Planeta Internacional Ltda (2004:628) lúdico é aquilo "que se refere a jogos, brinquedos ou divertimentos. Engraçado, jocoso.” É possível perceber que as noções de jogo e lúdico estão tão ligadas que parecem uma só.

É relevante voltar-se para definições ainda mais complexas, que tentam abranger de forma mais completa o seu real significado. Alguns pesquisadores bem conceituados defendem suas teses e, pelo que parece, ao menos neste ponto eles possuem algo em comum entre suas teorias. Ao tratar do tema, Bramante (1998) explica que “A ludicidade, como eixo principal da experiência de lazer, vem sendo uma das poucas unanimidades entre os diversos autores que teorizam sobre o significado do lazer, onde através dos mais diversos estudos redescobre-se a vocação inerente do ser humano que brinca e que joga, na sua mais pura essência antropológica.”

Assim o que aparentemente tornou-se claro é que uma das principais motivações do homem em busca do lazer é o aspecto do lúdico. Um dos autores que pretende clarear as informações sobre o desejo e comportamento do homem diante do lazer é Camargo (1998:22) que explica que o "homo ludens abomina a disciplina e a rotina. Procura ser relaxado, improdutivo e natural. Para se divertir, ele precisa ser receptivo - e não ativo em relação ao ambiente”.

Talvez se deva recordar novamente, neste momento, da atividade que mais se confunde com a ludicidade, ou seja, o jogo, e aqui se destaca o RPG como exemplo e tema desta pesquisa. O lúdico como motivação principal do ser humano em busca de uma maneira de fugir do mecanicismo, leva na maioria das vezes, ao jogo, isto porque provavelmente ele seja a ação mais natural ao homem, sendo divertido, não necessariamente produtivo e instintivo, tanto é que acompanha toda a história da humanidade. 
Talvez se torna necessário estar assim: relaxado e natural. Mas percebe-se que imprescindível mesmo é estar receptivo, para poder aproveitar o prazer que o jogo, ou neste caso, que o RPG pode proporcionar aos seus praticantes, não sendo assim a tendência seria que as regras que envolvem este jogo, que exige dos participantes desenvoltura e desembaraço, surtiriam efeitos diferentes do que o que normalmente se espera quando o praticam. Um detalhe a se destacar aqui é que existe uma espécie de regra entre grupos de jogadores que restringe o consumo de bebida alcoólica pouco antes ou durante as partidas de jogos, o que parece é que esta "proibição" tenta manter aquela idéia de estar natural, relaxado e receptivo citada acima.

Tendo em vista a forma como o jogo de RPG se desenvolve, a comparação e utilização das categorias do lúdico proposta por Callois são inegáveis a este estudo. Todas as quatros categorias foram percebidas no jogo, elas se subdividem em: aventura, competição, vertigem e fantasia, e pelo que foi observado estão inseridas no contexto das seções de jogos. Camargo (1998:34)

Ao que parece, quando um grupo de jogadores se reúnem, o que todos eles querem é esquecer, “dar um tempo” das exigências do mundo em que vivem e adentrar de forma completa ao mundo paralelo do jogo, mundo este cheios de desafios, enigmas, lugares exóticos e perigosos, onde o mesmo pode ser e fazer o que bem quiser, e viver uma realidade até então não vivida. Nada de importante do mundo exterior ao jogo parece ter alguma importância nesse momento.

Camargo (1998:34) tenta explicar como isso acontece com relação à categoria aventura: “A experiência lúdica da aventura tem por base a curiosidade, sendo, pois, uma forte motivação para o desenvolvimento da inteligência abstrata e da inteligência prática”. Assim o rpgista ávido por descobrir qual será a próxima façanha de que irá participar, a próxima personagem que terá que criar, o que irá acontecer depois que suas decisões forem tomadas, sempre estará envolvido mais e mais com o aspecto aventureiro do jogo.

Nas observações realizadas foi possível perceber que um dos fatores que mais empolgam os jogadores são as possibilidades de descobrir locais secretos, tesouros perdidos e arranjar encrencas nos bares espalhados pelas cidades e portos das cidades costeiras, para estes jogadores não há nada melhor do que isso para representar uma boa aventura. 
A aventura em si já se apresenta como é um ótimo atrativo para qualquer jogador de RPG. A curiosidade talvez seja um dos principais motivadores para tentar se resolver os mistérios e desafios propostos pelo mestre/narrador do jogo. É neste contexto que as outras categorias se inserem, pois, como afirma Camargo (1998:36) "para a criança, a motivação de participar de uma brincadeira só é menor do que a motivação de ser o primeiro a participar.” E aqui se insere a competição, mas não só competição em ser o primeiro dentre muitos, mas principalmente a competição em ser melhor do que já se foi antes. No caso do jogador de RPG, esta categoria provavelmente se apresenta no momento em que o mesmo tem que raciocinar e usar a sua percepção para atravessar um labirinto, por exemplo, e manter a sua vida e de seus colegas, talvez a idéia principal seja superação de si mesmo.

Acontece que numa partida de rpg, há a prerrogativa de que sempre haja competição entre os jogadores, não que uns estejam contra os outros, mas o desejo de ser melhor naquilo que os personagens podem fazer toma conta de cada um dos participantes. Ser o melhor ali dentro do contexto, traz vantagens e recompensas, famas e riquezas. Necessidades deste mundo paralelo do RPG, no entanto que mais parecem refletir as necessidades deste mundo palpável exterior ao jogo.

Ainda com base na observação dos jogos, identificou-se que muitos personagens eram construídos exclusivamente para desempenhar certas funções dentro do jogo, como por exemplo um personagem guerreiro, que deveria ter maior preocupação em melhorar as suas técnicas de combate, enquanto outros membros do grupo de personagens se preocupariam com outras atividades, como um mago ou feiticeiro que deve estudar para melhorar suas magias e o ladino tentando melhorar suas habilidades de furto e espionagem, e cada um deles tentando ser cada vez o melhor possível nas suas atividades para fazer com que o grupo todo alcance seus objetivos.

Com relação à vertigem, esta talvez esteja mais presente no RPG do que se possa imaginar, é claro que existem outras formas físicas de se alcançá-la, e muito vezes mais facilmente, como por exemplo, nos esportes radicais, no cinema com cadeiras que se movimentam sincronizadamente, nas montanhas-russas e nos tobogãs. Porém é possível atentar-se a um detalhe do jogo, questão que se trata aqui incansavelmente, o poder que o mesmo aparentemente possui de fazer com que o rpgista se envolva de tal maneira a sentir 
os calafrios que o seu personagem está sentindo por ter sido atingido na perna por uma flecha em meio às batalhas do mundo medieval.

Outro detalhe percebido foi a respeito da fissura que se torna tamanha a ponto de muitos dos jogadores lutam pela vida de seu personagem como pela sua própria chegando a desprender-se do mundo exterior e concentrando toda a sua energia naquela questão, neste momento pode-se observar ao assistir algumas seções de jogos que os praticantes se levantam, gritam, folheiam livros e mais livros de regras à procura de opções ou maneiras de burlar as regras para provar ao mestre condutor daquela partida que ainda há como o seu personagem sobreviver. Existem "lendas” entre os praticantes sobre muitos jogadores que, após anos de jogos com um mesmo personagem, choraram perante a morte do mesmo. Outra prova desta fissura, é que a média de tempo de jogo varia de 4 a 6 horas por partida, sendo que uma campanha, ou melhor, uma história narrada com vários capítulos, pode durar por mais de um ano, exigindo a atenção quase que total do mesmo neste período, isto é claro se o jogador pretende ter sucesso em suas atuações.

Quanto à fantasia, talvez esta seja uma das categorias do lúdico que mais facilmente se identifique no contexto de jogo de RPG, não só por que alguns cenários o exigem como elemento constitutivo, mas por que todos os jogos pedem que o jogador use sua imaginação e passe a fantasiar para poder aproveitar ao máximo as possibilidades que o RPG e seus personagens possam alcançar. Camargo (1998:39) explica que: “A quarta motivação para o exercício do lúdico é a fantasia, o desejo de ser diferente, de ser outro, de estar em lugares diversos”.

E este é um jogo fantasioso, tanto que ele realmente permite que você esteja em qualquer lugar do mundo, representado qualquer papel e fazendo qualquer coisa, mas desde que, e isto é claro, seja coerente com a história. Recordando que este tipo de regra de alguma maneira limita as ações do jogador é uma condição da própria idéia de jogo e é talvez o que a torne possível e ainda mais interessante de ser realizada. Como se vê, a fantasia faz parte do jogo de forma muito especial, e provavelmente mais do que qualquer uma das outras categorias.

O jogador de RPG parece querer estar naquele momento, naquela realidade paralela, mesmo que esta seja uma realidade fantasiosa, ele quer estar no mundo em que escolheu estar, voltar onde já esteve ou conhecer lugares novos, rever ou conhecer novas pessoas, agir de maneira simples ou realizar atos extraordinários, ser camponês, artesão ou 
alcançar tesouros e prêmios inimagináveis, o importante é que as possibilidades são múltiplas, o fato é que em certos momentos a fantasia e a realidade parecem fundir-se.

Assim se apresenta o lúdico como motivação para a busca do mundo do RPG e todas essas categorias devem provocar uma reação em seus praticantes de tal maneira que só vem reforçar a sua disseminação, pois esta se dá geralmente como uma notícia que saí de boca em boca, dito desta forma porque ao que aparenta é assim que se forma e se agrega novos adeptos ao jogo, do que se sabe não há propagandas em nenhuma mídia que convide e apresente o jogo a ninguém.

Provavelmente isso se dá de forma tão natural quanto um garotinho de escola que chama os colegas de turma para brincar. Mas uma vez é a atração e o poder de agregar que o lúdico possui que aos poucos vai juntando e formando o que muitas vezes é chamado de "turma", de "galerinha", e de tantos outros termos que variam dependo de fatores como idade, cultura, região. O que está associado com o que muitos autores preferem designar de Tribos Urbanas, e é assim que os mesmos serão tratados aqui: a tribo urbana dos rpgistas.

\subsection{A Tribo Urbana do RPG}

Para compreender melhor do que se trata este item da pesquisa, faz-se necessário tratar de um ponto que é essencial para o melhor conhecimento deste jogo e de sua forma de ação sobre seus jogadores, trata-se do que realmente é e representa uma tribo urbana.

Os grandes centros urbanos apresentam agrupamentos de jovens que possuem linguagem própria e indumentária estilizadas que obedecem a um padrão regular de comportamento. O diferente parece chamar a atenção, o impacto visual causado ao outro, não pertencente ao grupo, torna-se uma forma de identificação entre os membros dos grupos. A cor exótica, as correntes, pulseiras, botons, anéis, etc, são as formas mais fáceis de se identificarem os grupos. Há também outros aspectos como o interesse musical, cultural, sexual, políticos, entre tantos outros, que levam os jovens a se agruparem em tribos.

O Dicionário da Língua Portuguesa da editora Barsa Planeta Internacional Ltda (2004:1040) define Tribos como: “Cada um dos agrupamentos em que estavam divididos 
alguns povos da Antiguidade. Em antropologia, grupo social caracterizado por relativa coesão territorial e homogeneidade lingüística e cultural, com pequeno desenvolvimento da autoridade central e da organização política (...)”

Nas cidades, o processo de "tribalização" ou de formação de grupos de pessoas com interesses comuns é a maneira de, principalmente os jovens, resistirem à despersonalização no meio das multidões, de estabelecerem relações de companheirismo e de expressarem suas opiniões e interesses, fugindo das proibições da sociedade. É um sentimento de pertencer e ter a quem recorrer ou com quem contar para desafiar realidades impostas e ter condições de modificá-la. Maffesoli (1997:195) nos conta que:

\begin{abstract}
“(...) Não é inútil desenvolver as razões antropológicas, religiosas, políticas, estéticas, que permitam, em culturas e momentos bastante diversos, manifestação de entidades alternativas ao indivíduo. Pode ser a massa, a comunidade, a tribo ou o clã, pouco importa o termo empregado, pois a realidade designada é intangível; trata-se de um estar-junto grupal que privilegia o todo em relação aos seus diversos componentes. Signos precursores, como a cultura dos sentimentos, a importância do afetual ou do emocional, aparecem enquanto elementos que tornam essa grupalidade especialmente pertinente (...)”
\end{abstract}

É assim, que se explica da melhor maneira a força e a importância da tribo urbana para seus membros, conforme o autor citado acima não interessa do que ela é chamada e da maneira em que se manifesta, mas o simples detalhe de estar junto já lhe confere o poder de resistir a algo que não lhe parece agradável ou direito, aí então é possível ter uma cara, uma forma, uma identidade sem maiores preocupações com o que isto aparentará.

Os grupos geralmente são conhecidos pelos estilos que adotam, entre estes encontramos os Punks, Skinheads, Rappers, Gangues de pichadores, Skatistas, White Powers, Clubbers, Grunges, Góticos, Drag Queens, Rockeiros, Breakers. Estes são apenas alguns grupamentos juvenis, chamados pelos sociólogos de "tribos urbanas", encontrados mais facilmente nos grandes centros urbanos. 
A origem de todas essas manifestações parece ser a contestação. A violência, a apatia, o desleixo, a festa e a anarquia são as formas de contestação do mundo pósmoderno, dizem os sociólogos. O poder de uma tribo é tanto que Maffesoli (1997:247) afirma: “(...) muitos são os exemplos históricos sobre a capacidade de a realidade emocional impulsionar movimentos de massa contra o esperado (...)”. Entretanto aqui é possível acrescentar mais: não só maneira de contestação, mas, as tribos urbanas também são uma forma de aliviar contenções a que os indivíduos são obrigados a fazer todos os dias, há uma necessidade de distração, de conforto e consolo para o corpo e para a alma.

Provavelmente as manifestações de repudio e a revolta com padrões dominantes sejam um pilar importante na formação destas tribos, contudo, o que mais interessa neste momento é o fato de que se reúnem também, ou quase que principalmente, no intuito de divertir-se, independente de suas ações, essas parecem sempre ter a diversão como meio ou meta final para qualquer coisa. Desta maneira, o que se pode concluir é que se encontrar com o objetivo do lúdico é uma das características de uma tribo urbana.

Assim, através do lúdico se estabelece um vínculo sem igual, vide pelas associações, sindicatos, organizações ou quaisquer empresas que ofereçam a seus funcionários clubes, eventos e/ou atividades recreativas, na intenção de suprir-lhes as carências de prazer e de diversão, além de os manterem de certa forma focadas às questões ou relações de trabalho.

No caso do RPG, não poderia ser diferente, vários são os motivos para os jogadores se reunirem. De acordo com estudos efetuados, a freqüência desses encontros é de no mínimo uma vez por semana, para realizarem partidas de jogos e para conversarem sobre o tema, nas suas linguagens próprias, e isto não poderia ser diferente. 
À primeira vista o que parece é que os rpgistas não teriam características determinantes que os classificariam parte de uma certa tribo urbana, tais como a indumentária, a preferência musical ou manifestação de revolta com as estruturas dominantes, desigualdade social ou posicionamento político. Realmente, o que normalmente se encontra entre estes jovens, é o interesse pelo jogo, isto apenas, pelo menos para eles, os tornariam uma tribo, e agora sim com linguagem própria, com espaços públicos destinados a encontros dos mesmos, com organizações destinadas a promover jogos e defender interesses em comum.

Contudo é claro que é possível traçar alguns perfis, afinal o que está implícito para que todos vejam, mesmo que a "grosso modo", ou tomando como base aquele reparte de indivíduos que mais se destacam como o jogador de RPG, é que o rpgista, geralmente se inclui na faixa etária dos adolescentes e jovens, sendo em sua grande parte do sexo masculino. Agora, partindo para alguns dados, isto se torna mais evidente. Em entrevistas e questionários realizados para esta pesquisa verifica-se que o rpg costuma ser jogado por pessoas entre 12 e 30 anos, sendo que sua maioria está entre os 20 e 29 anos de idade, levando em consideração que jogadores mais velhos quase sempre estão no meio acadêmico ou possuem formação universitária.

É interessante comentar que, criou-se uma tradição entre alguns rpgistas, de se vestirem de preto, devido ao enorme sucesso que o jogo Vampiro: a máscara causou. Baseado na literatura de Anne Rice, o jogo fala de vampiros vivendo escondidos entre os mortais do mundo moderno, ocorre que, alguns, fascinados pelo mundo gótico do mesmo, decidiram adotar essas vestimentas “sombrias” na vida cotidiana. Apesar disso parecer intrigante, não é muito diferente de vestir uma camiseta com nome de uma banda de rock, ou usar um penteado de alguma atriz do cinema, por exemplo. Revista Dragão Brasil no 109 (2004:20).

Assim, se apresenta uma tentativa de justificar a indumentária de grande parte dos jogadores, grande parte porque mesmo muitos sendo adeptos ao preto ainda se destacam aqueles que não aderiram a esta moda. Um dos entrevistados dessa pesquisa afirma que: “(...) acho difícil você encontrar alguém na rua que você consiga identificar como jogador de rpg analisando a sua roupa. Só se a camisa dele tiver alguma referência 
ao jogo de rpg (...)” Outro detalhe a ser levado em consideração é o gosto musical da maioria deles, como conta outro entrevistado:

"É engraçado isso aí! Por que, apesar de ser bastante comum, ter muita gente do rock, ter muita gente de preto no rpg, se você der uma olhada tem pessoas completamente... É um grupo muito eclético (...) a primeira vez que uma jogadora foi jogar conosco (...) encontra 0 cara de shortinho, jogador de futebol, camiseta, óculos escuro na cabeça, e parecendo um pagodeiro. Ela esperava encontrar um rockeiro né? (...) Tem muita gente do rock? Tem muita gente que se veste de preto? Tem! Mas não quer dizer que são todos, eu conheço muita gente que faz parte de outros grupos (...)"

Assim o gosto musical revela um pouco mais do rpgista, não que se possa generalizar, mas é possível perceber que o rock, ou seja, que a música, talvez uma das ferramentas mais lúdicas que se conhece, e lembrando que o lúdico estabelece vinculo entre pessoas, seja um dos elos, uma das características que dá homogeneidade a esta tribo urbana. Tanto é que um dos entrevistados revela “(...) a maioria é rockeiro, não sei bem por que, mas quase todo mundo que gosta de rpg, gosta de rock(...)”

O mais interessante nessa estatística é que metade dos jogadores estão cursando ou terminaram o nível superior e a outra metade se conferido e comparado a sua idade e o seu grau de escolaridade, verifica-se que o mesmos correspondem ou estão a cima ao padrão que é exigido pelos órgãos responsáveis em garantir uma educação adequada aos brasileiros. Desta forma torna-se claro que a situação cultural e patamar de conhecimento deste grupo é sem dúvida um destaque incomum na sociedade brasileira.

Todos estes aspectos, acima relacionados, contribuem para caracterizar os rpgistas como pertencentes a um grupo, ou melhor, a uma tribo urbana. Lembrando, contudo, que o interesse pelo jogo é o principal motivador para a reunião destes jovens. Rodrigues (2004:66) explica que “A pessoa que se interessa por RPG, em geral, compra 
um livro de regras que a ensine a jogar. Compra o livro de regras e, se o gosto pelo jogo se estabelecer, os suplementos.” E é assim que se começa a criar um estilo, um interesse, um vínculo, e um conhecimentos por termos que só naquele contexto serão compreendidos. Talvez estes aqui seriam rituais, como aqueles, geralmente, necessários para se pertencer a um grupo, aparentemente é assim que se começa a mostrar a lealdade pelo motivo que mais interessa aos pertencentes desta tribo.

No Brasil, há três grandes publicações que podem, de certa forma, estabelecer uma subdivisão simbólica entre os praticantes do RPG, são eles: Dungeons and Dragons, Vampiro: a máscara e GURPS. Dungeons and Dragons foi o primeiro RPG a ser publicado nos Estados Unidos e até hoje é o mais jogado no mundo. Geralmente seus jogadores se interessam por história medieval, fantasia e aventuras épicas, além do gosto por combate com armas brancas e magias.

Vampiro: a máscara trata sobre o mito dos vampiros e sobre as dificuldades de se sobreviver em uma sociedade sobrenatural às margens da sociedade mortal, ou seja, os humanos, mas ao mesmo tempo estando infiltrado e determinando os rumos dos principais acontecimentos da sociedade. O interessante nesse jogo, e que também chama bastante atenção, é que cada vez mais, ele tem atraído o público feminino para as mesas de jogos. Talvez por causa da temática do cenário, as mulheres tenham se interessado por este jogo, mais do que com os outros.

GURPS, que se tornou particularmente famoso e utilizado pelos rpgistas por causa da sua generalidade, se parece muito com um programa de computador, sem cenário ou enredo pré-determinado, ou seja, o jogo somente diz quais são as regras a serem utilizadas, e os jogadores e o mestre, decidem em qual cenário e época querem jogar, não se prendendo a nenhum enredo preestabelecido pelos autores do jogo.

Essas três publicações são as mais conhecidas e jogadas entre a tribo do RPG, e de alguma maneira elas contribuem para suas “classificações” em o que aqui será chamado de "sub-tribo", é claro que o mercado oferece muito mais títulos, e com certeza, existem grupos que não jogam nenhuma destas três publicações citadas, preferindo outros, tais como jogos voltados a temas relacionados a viagens espaciais, guerras históricas, terror 
futurístico, investigação policial e etc, porém de alguma maneira estas são as que mais se destacam.

Devido a grande quantidade de publicações disponíveis no mercado e aos vários estilos e temas, é fácil notar que os rpgistas sempre se agrupam pelo jogo escolhido por seus participantes. Há sempre aqueles que gostam mais de fantasia medieval do que terror moderno, ou aqueles que preferem um sistema de regras mais fáceis, enquanto outros preferem regras mais complexas e mais voltadas à realidade, e aí de acordo com seus interesses também começam a surgir suas características que de alguma maneira diferenciam os jogadores como uma tribo urbana.

No caso dos fascinados pelas histórias medievais é mais fácil encontrar aqueles que não temem na hora de vestir uma fantasia de época e sair para um jogo, por exemplo. Um outro caso é dos interessados em narrações do sobrenatural, que também se vestem como seus personagens e se reúnem em lugares determinados para jogar o Live Action, que seria mais ou menos como uma interpretação teatral onde cada um deve ir vestido de acordo com o seu personagem, e se comportar adequadamente ao seu personagem, como se fosse o próprio personagem.

Existem ainda, aqueles que se interessam pelos super heróis e pelos desenhos animados japoneses e estes talvez são os que chamem maior atenção, pois sem ao menos hesitarem, saem pelas ruas com as vestimentas de seus heróis ou anti- heróis preferidos, além de promoverem até concursos, já vistos no mundo todo, para exibirem suas fantasias, conhecimentos e fazerem aquilo que tanto gostam: jogar.

Com tudo o que já foi revelado, evidencia-se, que os rpgistas, se encaixam nos argumentos acima colocados e são considerados como uma tribo urbana, tudo devido ao seu interesse em comum pelo jogo, motivo pelo qual estes jovens se reúnem nos finais de semana nas casas dos membros e, em muitas vezes, em locais públicos escolhidos pelos mesmos, que passam a ser utilizados para a prática do jogo.

2.6.1. Apropriação de espaços urbanos pela tribo dos rpgistas 
A apropriação de um lugar geralmente ocorre quando um indivíduo, ou um grupo de indivíduos “toma” um local como "propriedade” sua. Desse modo, o espaço torna-se o objeto da apropriação. Este espaço, em conjunto com as características dos indivíduos, é que darão a identidade da apropriação. Lembrando que é da ligação entre o indivíduo, o espaço e a apropriação que surge o meio urbano, a cidade, o local ao qual seus habitantes estão inseridos.

Os grandes centros urbanos são criações do mundo pós-industrial. Criados em conseqüência da revolução industrial, com objetivos totalmente utilitários e econômicos. Mas que com o decorrer do tempo, alguns, tornam-se antíteses à presença dos homens.

Zukin (2000:105) descreve como se dá o desenvolvimento das cidades modernas:

\begin{abstract}
"Os centros das cidades fazem brotar aranhacéus em 'distritos financeiros' e museus de arte em 'distritos culturais', e os dois distritos normalmente se desenvolvem ao mesmo tempo. As empresas privadas organizam muitos serviços básicos, de transporte a saneamento, que eram anteriormente fornecidos pelo Estado. Os espaços públicos são 'domesticados' por shopping centers e cafés. Enquanto isso, as crescentes populações de migrantes e imigrantes tornam as cidades mais diversificadas, transmitindo a cultura da cidade oficial por meio de linguagens e lugares alternativos."
\end{abstract}

É importante notar como a cidade se desenvolve e como as suas edificações influenciam o modo de vida dos indivíduos. Ao analisar Brasília e o Distrito Federal, todos deparam-se com uma peculiaridade, a cidade foi planejada e concebida com amplos espaços, para compor uma baixa densidade demográfica. Como é sabido por todos, o crescimento das cidades satélites e a ocupação urbana desorganizada desenvolveram uma serie de assentamentos e até a criação de novas cidades no Distrito Federal e entorno.

Segundo pesquisa de Waiselfisz, feita para a UNESCO (1997), Brasília é considerada, pelos jovens residentes no Plano Piloto, como uma redoma, uma cidade 
protegida, onde a organização espacial é considerada um fator de distanciamento entre as diferentes pessoas. Abramovay, e tal; (2000:38).

Em contrapartida, o espaço urbano de Brasília foi planejado com o intuito de permitir às pessoas que moram dentro de seus limites disponham de quadras de esportes, comércio variado e transporte de fácil acesso.

O que geralmente se percebe é que, dentro deste contexto de planejamento, e com as facilidades que permitem aos jovens se locomoverem e se encontrarem, grupos de jovens se encontram e se espalham em diversos locais de Brasília. Porém esta conquista e apropriação ocorre gradualmente. A princípio, os usuários irão se adaptar ao meio. Provavelmente o que ocorre é que antes da apropriação ser legitimada, ocorre um “estranhamento” do lugar, o que fará com que a pessoa perceba o espaço em todas as suas características. Depois do estranhamento e do reconhecimento do local a apropriação começa a acontecer gradualmente. A pessoa que antes era obrigada a adaptar-se ao meio começa a fazer adaptações no local. Surge então uma simbiose, onde pessoa e lugar vão depender um do outro reciprocamente. A apropriação vai muito além da imagem própria descrita acima. Ela trás a construção do significado, da identidade, Raggi (2000).

Entre estes grupos, encontra-se o dos rpgistas. Conforme pesquisa de campo realizada, os praticantes do RPG geralmente encontram-se em lojas voltadas para o público alvo, tais como a Kingdom Comics e a Mundo do RPG, e mais recente, o SESC da quadra 504 sul, que abriu espaço para uma gibiteca e possui mesas disponíveis aos jogadores.

A Loja Mundo do RPG está localizada dentro de um shopping de grande movimentação, tornando-o de fácil visualização para qualquer praticante do RPG, e servindo para alguns como ponto de encontro. Esta loja oferece produtos importados, dados e miniaturas em chumbo voltados aos temas dos jogos.

Já a loja Kingdom Comics oferece a seus usuários sessões de jogos todos os sábados a partir das 14 horass. Além de livros de RPG, esta loja oferece a seus clientes diversos opções ao público alvo, como por exemplo, camisetas, revistas em quadrinhos, jogos de baralho - card games, além de outros produtos voltados especificamente para o RPG, como dados, complementos e miniaturas em chumbo.

O SESC da 504 sul, além de possuir uma gibiteca e oferecer mesas para a prática de jogos, tornou-se um local apropriado para o encontro de jogadores por que além de 
ficar aberto até às 22 horas, é de fácil acesso a qualquer habitante de Brasília, possuindo uma parada de ônibus bem a sua frente, a cerca de dez metros da entrada. Neste local é freqüente a marcação de reuniões entre os jogadores do "Brasília By Night" (nome da dado a organização e ao grupo de jogadores de Live Action) que costumam acontecer na quinta-feira a partir das 18 horas. Isto aconteceu devido há um programa de divulgação do RPG que o SESC ofereceu a seus associados há alguns anos atrás, este evento ocorreu durante um mês e sempre nas quintas-feiras, o aconteceu foi que mesmo depois do fim do evento os jogadores continuaram a se reunir naquele local e criaram quase que uma tradição de se encontrarem ali neste mesmo dia da semana, ainda que não fossem jogar.

\subsubsection{A linguagem própria do "rpgista"}

A linguagem é um processo mental de manifestação do pensamento e de natureza essencialmente consciente, significativa e orientada para o contato interpessoal. Apesar do processo da linguagem ser essencialmente consciente, entretanto, entende-se que o fluxo e a articulação desta provém de camadas mais profundas e não conscientes, tais como do subconsciente e inconsciente. $\mathrm{O}$ estudo da linguagem dividi-se em duas partes: a expressão verbal e expressão gráfica. Ambas expressões são um conjunto de sinais próprios de cada língua com os quais se manifestam os pensamentos, tanto na expressão verbal quanto na expressão gráfica, Ballone (2001).

A manifestação do pensamento através da linguagem é característica primaria de qualquer cultura, desempenhando papel fundamental na vida em sociedade, através dela é possível transmitir a experiência humana. Supõe-se que a linguagem, traço distintivo do homem, começou a desenvolver-se por volta de 1,5 milhão de anos atrás, com o Australopiteco, ou "macaco-homem", Encontrado no texto Breve história da linguagem, em web site (2005).

A linguagem é o traço que melhor define a espécie humana. Todo esse sistema de expressão permite a comunicação entre os indivíduos que partilham de um mesmo meio de signos convencionais, sejam escritos ou falados, podendo estes signos até serem visuais, auditivos, táteis e etc.

Dentro da linguagem, ocorre um fenômeno interessante, a gíria. Criada por necessidade de sigilo ou por moda, a gíria tem vida efêmera, embora algumas criações 
vocabulares possam ser eventualmente incorporadas à língua. Ao tratar sobre esse tema, Pretti (1983:66) explica que:

\begin{abstract}
"Embora a gíria não ofereça as mesmas perspectivas em todas as línguas, pode se dizer que ela, na essência, constitui-se num vocabulário criptológico, ligado a vida e à cultura de um grupo social restrito. Sua função como linguagem fechada, além de simples veiculo de comunicação, é também a de defesa e preservação de classe. E essa característica é que melhor define sua condição de signo de grupo, elemento de auto-afirmação e identificação dos falantes”.
\end{abstract}

Muitas vezes a gíria nasce entre grupos sociais que não desejam ser compreendidos por outras pessoas, ou ainda pode tratar-se apenas de uma linguagem típica do meio em que se vive. Há também, independentemente do grupo social a que pertençam os falantes, a intenção de representar estilisticamente e mais expressivamente determinada realidade através do uso da gíria, e isto lhes confere, inclusive, uma identidade. Grande Barsa CD (2004)

Por tratar-se de um grupo específico da sociedade, ou melhor, uma tribo urbana, os praticantes de RPG também possuem sua própria linguagem, o que também pode ser caracterizada como gíria, conforme se pode observar na reportagem da Revista Dragão Brasil no 109 (2004:21):

"Devido à enormidade de termos técnicos em RPGs, siglas são muito comuns (claro, até o nome do jogo é uma sigla!). Quase tudo é abreviado, incluindo os próprios nomes dos jogos. Eis algumas:

3D\&T: Defensores de Tóquio $3^{\circ}$ edição. Jogo sobre heróis baseados em mangá, anime e videogames.

D\&D: Dungeons \& Dragons, ou "Masmorras e Dragões". O primeiro jogo de RPG do mundo, baseado em histórias de espada e magia, envolvendo cavaleiros, magos, elfos, dragões e outras criaturas fantásticas.

GURPS: Genéric Universal Role Play System, ou "Sistema Genérico Universal para Jogos de Interpretação”. A maioria dos RPGs é voltada para este ou aquele gênero. (...) 
D20: é o código para um dado de vinte faces, mas também é o nome do sistema de regras adotado no D\&D, o Sistema D20. Um "sistema de regras" é mais ou menos como o sistema operacional de um computador - ele determina que livros ou suplementos você pode usar em conjunto com este ou aquele jogo. (...)

PC ou PJ: Player Character, ou Personagem Jogador. É um herói aventureiro (na maioria dos jogos) que será controlado por um jogador. Inventar esse personagem também faz parte da diversão.

NPC ou NPJ: NonPlayer Character (Personagem Não-Jogador), ou personagem do Mestre. São todos os outros personagens da história, sejam aliados dos heróis, adversários, vitimas, monstros ou vilões(...)

PVs: são os pontos de vida. (...) É o mesmo que a "barra de energia" em um videogame.

PMs: Pontos de Magia. Em alguns jogos, eles são um tipo de "combustível mágico", servem para ativar magias e outros poderes especiais(...)

Como foi possível notar, a quantidade de siglas e códigos ligados ao jogo de RPG é incrivelmente enorme, pois cada RPG tem sua própria coleção de siglas e termos técnicos, e seria impossível reproduzir todos aqui. Eles são explicados nos livros básicos de seus respectivos jogos. Revista Dragão Brasil nº 109 (2004:21)

Como se pode notar, é realmente imensa a quantidade de termos e siglas que permeiam o universo do RPG. Talvez seja isso, a linguagem própria do jogo, o fator fundamental para caracterizá-los como um grupo social dentro da sociedade, é claro que não é só isso que torna os rpgistas uma tribo urbana, mas a utilização de signos, siglas, gírias e termos técnicos que somente os praticantes reconhecem e entendem, faz com que eles se reconheçam entre a sociedade como um todo, e também os auxiliem no entendimento das expressões e pensamentos que tentam transmitir uns para os outros.

\subsubsection{A representação e a construção de personagens}

Role playing, em sentido estrito, significa interpretação de papéis. Contudo, não é exatamente isso o que os jogadores de RPG fazem, eles geralmente não interpretam, mas sim representam. A representação é praticada por todas as pessoas, em todos os lugares do 
mundo, mesmo sem se ter consciência desta atitude. Conforme explica Goffman (1985:15):

"Afirmei que quando um indivíduo chega
diante de outros suas ações influenciarão a
definição da situação que se vai apresentar. Às
vezes, agirá de maneira completamente
calculada, expressando-se de determinada
forma somente para dar aos outros o tipo de
impressão que irá provavelmente levá-los a
uma resposta especifica que lhe interessa obter.
Outras vezes, o individuo estará agindo
calculadamente, mas terá, em termos relativos,
pouca consciência de estar procedendo assim".

Como se pode perceber, a representação faz parte da vida de todos, e é isso o que os jogadores de RPG costumam fazer: representar personagens. Isto é o que eles aparentam precisar e gostar de fazer quando estão se dedicando ao seu passatempo. Talvez seja uma representação de outras pessoas, de alguém famoso ou da tevê, de um herói, ou da percepção que muitas tenham de si mesmo.

Mas essa interpretação dificilmente pode ser igualada a representação praticada por atores profissionais. Pois diferentemente do que é o teatro na maior parte das vezes, mas ainda assim semelhante a este, este tipo de diversão possui uma representação espontânea e criativa na medida em que se desenrola. A representação não é desprovida de objetivos ou razão, mas ocorre de forma livre, solta e sem rumos predeterminados, tendo em vista que cada personagem age de acordo com a vontade do jogador. Para cada jogador, o seu personagem é único. Sem igual em qualquer outro lugar. O processo de construção de personagem propicia essa construção impar, tornando-o particularmente incomum desde o início de sua construção. Entretanto, os jogadores baseiam-se em fontes comuns e conhecidas para começar a montar seus personagens, buscando nos fatos cotidianos e corriqueiros da vida a inspiração para a construção de seu personagem, e só depois de conseguir determinar um estereotipo, o jogador consegue definir as particularidades do seu personagem. Os próprios livros básicos de RPG já oferecem essa opção para os jogadores, com suas classes e kits de personagens pré-estabelecidos o que provavelmente começaria a quebrar a lógica da ludicidade que envolve o jogo, mas esta já é uma outra questão que não cabe ser aprofundada aqui. 
A respeito da construção de personagens, seja no RPG, ou na literatura, e sua correlação com as impressões dos seus construtores, Rodrigues (2004:37) aponta especificamente como isso ocorre:

\begin{abstract}
"A personagem fictícia tem como principio as pessoas na vida, mas não as pessoas em carne e osso, porque estas existem em função da representação que se tem delas. O que costuma ocorrer, na vida, é a inconsciência da representação produzida pelo olhar. Todo ser humano real é representado aos olhos de um outro ser, também real, que o enxerga não necessariamente da maneira que ele é ou imagina ser. Na vida, como na arte, existem representações, existe invenção sobre o que vemos e sentimos. A personagem é baseada no ser humano sobre outro tomando como matéria-prima, ou fonte de inspiração, não o ser humano em si”.
\end{abstract}

Portanto, fica evidente quais são os fundamentos em que os jogadores se baseiam para construir seus personagens: a própria impressão que possuem da vida cotidiana, do mundo ao qual pertencem e de si mesmos. É certo que muitos jogadores buscam diversas fontes e pesquisas para construir seus personagens e torná-los cada vez mais individualizados, mas estas particularidades tão avidamente buscadas dependem e muito do imaginário daqueles que o constroem. Além disso, haverá sempre a própria impressão do jogador sobre o que ele percebe da vida inserida no personagem, e exteriorizada na sua forma de representar esse personagem.

\title{
2.7. O RPG e a Sociologia do Lazer
}

Conforme observação, verificou-se que o RPG desempenha um papel tão importante na vida dos indivíduos que o praticam que ele chega a ser a atividade que estes mais gostam e se dedicam a fazer no seu tempo liberado de obrigações profissionais e sociais. Com base nessa perspectiva, há a possibilidade de se fazer uma breve comparação desta situação com a proposta de Dumazedier sobre o lazer.

Ao tratar sobre o tema, Waichman (1997:89) cita que: “O ócio, para Dumazedier, tem três funções principais: 


\section{Descanso (délassement)}

2. Diversão (divertissement)

3. Desenvolvimento (dévelopment)"

Sendo o ócio, para Dumazedier, uma oportunidade que as pessoas possuem para descansar, se divertir ou se desenvolver pessoalmente, cabe aqui estabelecer uma comparação a esta proposta com o RPG.

O descanso das atividades profissionais pode ser alcançado de várias formas, seja pelo simples deitar-se e dormir até a praticar atividades físicas em academias. As pessoas que estão cansadas de trabalhar, geralmente estão interessadas em se liberar das suas obrigações, não que realmente não estejam cansadas, mas subjetivamente, o seu maior interesse é esquecer de seu trabalho e praticar alguma atividade que a faça relaxar, despreocupar-se dos problemas do âmbito profissional.

A diversão, o lúdico é o maior atrativo para se liberar do tédio das atividades cotidianas, todos se sentem bem mais alegres em pensar na possibilidade de se divertir. Tudo o que envolve diversão traz prazer para as pessoas, principalmente para aqueles que querem livrar-se do tédio e das obrigações diárias.

O desenvolvimento, aqui sendo colocado como o desenvolvimento da personalidade, é encarado como uma liberação dos automatismos das ações cotidianas, ou seja, o ócio pode levar há uma participação social e cultural desinteressada, mas ao mesmo tempo produtiva e gratificante.

Tendo em vista as três principais funções que o ócio pode proporcionar, citadas acima, é interessante destacar que, conforme o que demonstrou as pesquisas, principalmente a última pergunta aplicada no questionário, o RPG tem a capacidade de desempenhar, para seus praticantes, todas elas satisfatoriamente, sejam interdependentemente ou em coexistência mútua. Não há como negar que o RPG traz diversão aos seus praticantes, afinal os mesmos afirmam que este é o principal objetivo pelo qual se joga RPG, e que o lúdico é fator motivador de reunião desse grupo.

O desenvolvimento da personalidade é provavelmente se dá devido aos laços sociais que são criados em torno do jogo, e devido também à mudança de comportamento que é exigido, de forma implícita, é claro, para que o jogador possa interagir durante as partidas de forma significativa e com sucesso em suas ações, assim uma pessoa mais 
tímida acaba que se "rendendo" e tomando atitudes um tanto quanto mais ousadas para alcançar o desempenho que buscam no jogo.

O desenvolvimento cultural também é notável, devido a enorme quantidade de pesquisas e estudos que os mesmos necessitam fazer, e muitos a fazem para melhor caracterizar seus personagens e criar histórias baseadas em fatos históricos ou mitológicos, há também a necessidade de ler uma quantidade razoável de livros para ficar ao par de regras e das histórias que estão se desenrolando.

O descanso, por ser muito subjetivo, é mais difícil de ser claramente detectado e comprovado entre os praticantes, mas sem dúvidas, e baseado nas respostas dadas pelos questionados, é possível observar que muitos dos jogadores sentem-se melhor, mais relaxados e alegres depois de uma partida de RPG, além disso, não é necessariamente o fator descanso que caracteriza uma atividade recreativa, pelo contrário, muitas vezes esse tipo de ação exige muito física e intelectualmente de quem a estar praticando, mas recompensa pelo prazer que proporciona. Contudo, não se pode esquecer que o descanso também pode ter outra vertente relacionada com a recomposição do bem estar, de desastressamento e evasão.

Em síntese, as pesquisas tornam claro que o RPG é uma atividade recreativa que tem a capacidade de desempenhar um importante papel na prática do lazer dos indivíduos que estão envolvidos com este jogo. Dentro da sociologia do lazer proposta por Dumazedier o RPG parece atender as três funções básicas que qualquer atividade lúdica deveria alcançar e oferecer, o que a infere a atividade importante valor social, e uma provável melhoria da sociedade, contudo esta é uma outra questão que não cabe ser aprofundamente discutida aqui. 


\section{APRESENTAÇÃO DOS DADOS}

Apresentação dos dados referentes às entrevistas realizadas, questionários aplicados e observação in loco para melhor conhecer os jogadores de RPG e compreender a importância desta atividade recreativa como elemento de diversão entre os seus praticantes.

\subsection{Entrevistas}

As duas entrevistas foram realizadas em dias diferentes e locais diferentes. Os dois entrevistados estão envolvidos com RPG há pelo menos 4 anos, fato que lhes confere um conhecimento em torno do objeto deste estudo que se faz muito importante explorar. As suas opiniões e pensamentos refletem o que a maioria dos jogadores pensam a respeito do RPG e de suas particularidades.

\section{$\underline{\text { Entrevista } 1}$}

Entrevistado: Bruno Benitz

Data da entrevista: 31 de março de 2005

Envolvimento com o RPG: Coordenador nacional do projeto Brasil By Night, organização que promove jogos de RPG live action.

Comentários:

O entrevistado conta que é novo no RPG, mas que em tudo o que faz é sempre muito persistente. Começou a jogar no ano 2000 e não parou mais. Após algum tempo ingressou no Brasília by night, organização de jogadores que promovem jogos live actions, ou seja, ação ao vivo. Em pouco tempo tornou-se coordenador local e depois nacional da organização.

Ao comentar sobre o perfil dos jogadores, o entrevistado revelou que há muitas pessoas que gostam de rock ' $\mathrm{n}$ roll, mas que ainda assim o grupo é muito eclético. 
Continuando, ele afirmou que a maioria dos jogadores é pertencente a faixa dos 20 aos 30 anos, apesar de ter praticantes mais velhos e muitos mais novos que 20 anos.

Questionado sobre a popularidade do RPG ser maior entre os jovens, o entrevistado respondeu que a maioria dos jogadores estudam ou trabalham e estudam, e que além disso, possuem outras obrigações particulares que acabam por tornar um pouco difícil a prática constante do jogo. Disse que há também um certo preconceito contra as pessoas que estão na faixa etária adulta praticarem um jogo vinculado a juventude e adolescência.

O entrevistado ainda observa que no grupo de RPG, assim como em qualquer grupo, sempre irá existir a comunhão de linguagem, pensamentos e expressões em comum, como ocorre com qualquer tribo urbana.

Ao responder sobre a influência do jogo na vida dos praticantes o entrevistado declarou que o RPG: “(...) ajuda na socialização sim. Eu não tenho dúvidas. Você é obrigado a..., durante o live, obrigado, entre aspas, a conversar com pessoas que você não conhece, é uma coisa muita boa contra timidez, que muita gente tem, muito parecido com o teatro, você é forçado a interagir a botar sua cara a tapa, a falar. Eu mesmo, vou lá na frente, tem quarenta, cinqüenta jogadores olhando pra mim, e tendo que falar (...).”

Finalizando, o entrevistado explicou que o RPG ainda não se tornou muito popular devido ao custo que possui, devido à quantidade de livros que ainda não foram traduzidos para o português e o gasto pessoal com alimentação e transporte até os locais de jogos.

\section{$\underline{\text { Entrevista } 2}$}

Entrevistado: Gualter Henrique

Data da entrevista: 14 de abril de 2005.

Envolvimento com o RPG: Administrador local do fã clube oficial da editora White Wolf, conhecido popularmente como The Camarilla, mas registrado no Brasil sob o nome Associação Brasileira de Jogadores de RPG.

Comentários: 
O entrevistado declara que já joga RPG há pelo menos 7 anos. Conheceu essa atividade por meio de revistas de vídeo games e desde então continua jogando por diversos motivos, sendo o principal a diversão. Frisou a importância do jogo para ele, o que demonstrou ser muito grande devido, principalmente, ao fato de que somente neste jogo é possível, para o mesmo, fazer o que se quer fazer, ter liberdade de ação e de tomar as decisões que achar mais certo.

Ao responder sobre o perfil dos jogadores o entrevistado declarou que apesar de que há alguns anos só era possível encontrar jogador do mesmo grupo social, hoje em dia já é possível encontrar pessoas que jogam em quase todos os lugares, que o grupo está mais eclético e que o RPG está difundido. E que embora a maioria ainda seja jovem na faixa dos 20 anos de idade e que também são na maioria das vezes “rockeiros”. Ele também declarou que o sexo predominante é o masculino e que a comunicação entre os jogadores é feita através de uma linguagem muito particular, chamando-a de "dialeto", devido ao fato de existir uma enormidade de termos técnicos e gírias que só os jogadores conhecem.

Ao falar sobre a popularidade do jogo entre os jovens, o entrevistado respondeu afirmando que os jovens são mais receptivos as novidades, que possuem vontade de conhecer novas formas de se divertir e que o tempo que possuem para isso influencia nessa escolha por divertir-se com o RPG.

Ao ser questionado sobre o jogo se concentrar em grupos específicos que costumam ter a mesma linguagem e interesses em comum, o entrevistado respondeu que não vê a situação dessa maneira, declarando que “Acho que não, se bem que, isso até pode ser verdade, mas não é assim tão rígido, por que eu acho que pra alguém querer jogar rpg, basta ter vontade de conhecer, pode ser que o cara nunca tenha ouvido falar disso antes, não é difícil acontecer, mas o que ocorre muito, é um certo receio que muitas pessoas possuem de conhecer algo de novo, algo que é estranho a sua realidade, eu mesmo já vi, muita gente dizer que não joga rpg por que é coisa do demônio (...).”

Finalizando, o entrevistado declarou que entende que o jogo ainda está se desenvolvendo e acredita que daqui algum tempo se tornará tão popular quanto o vídeo game é hoje. 


\subsection{Questionários}

Apresentação dos dados referentes a perguntas mais relevantes dos questionários que foram aplicados nas lojas Kingdom Comics, Mundo do RPG e no SESC da 504 Sul com o objetivo de conhecer melhor aspectos relacionados aos espaços e seus freqüentadores, esses foram realizados no período de 31 de março a 14 de maio de 2005. Aqui estão apresentados os dados de maior interesse para realização desta pesquisa. ${ }^{1}$

Questão 2 - Sexo predominante dos praticantes:

TABELA B - Sexo

\begin{tabular}{ccc}
\hline Sexo & Número de respostas & Percentual \\
\hline Masculino & 31 & $77,5 \%$ \\
Feminino & 09 & $22,5 \%$ \\
\hline Total & 40 & $100 \%$ \\
\hline
\end{tabular}

Fonte: Oliveira, Alyne. A partir de dados coletados em trabalho de campo de março a maio de 2005.

GRÀFICO B - Sexo

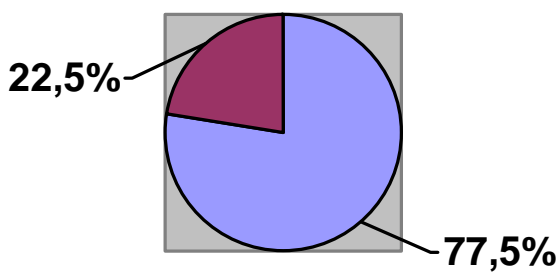

$\square$ Masculino

$\square$ Feminino

Fonte: Oliveira, Alyne. A partir de dados coletados em trabalho de campo de março a maio de 2005.

Comentário: Observa-se claramente a predominância do sexo masculino entre os praticantes de RPG, sendo que 77,5\%, ou seja, mais de três quartos do total de entrevistados são homens contra 22,5\% de mulheres praticantes.

\footnotetext{
${ }^{1} \mathrm{O}$ resultado de algumas questões foram suprimidos a sua menor relevância para a análise e interpretação de dados importantes à pesquisa..
} 
Questão 3 - Estado civil:

TABELA C - Estado civil

\begin{tabular}{ccc}
\hline Estado civil & $\mathrm{N}^{0}$ de respostas & Percentual \\
\hline Solteiro & 33 & $82,5 \%$ \\
Casado & 05 & $12,5 \%$ \\
Viúvo & 00 & $0 \%$ \\
Divorciado & 00 & $0 \%$ \\
Outros & 02 & $5 \%$ \\
\hline Total & 40 & $100 \%$ \\
\hline
\end{tabular}

Fonte: Oliveira, Alyne. A partir de dados coletados em trabalho de campo de março a maio de 2005.

GRÁFICO C - Estado civil

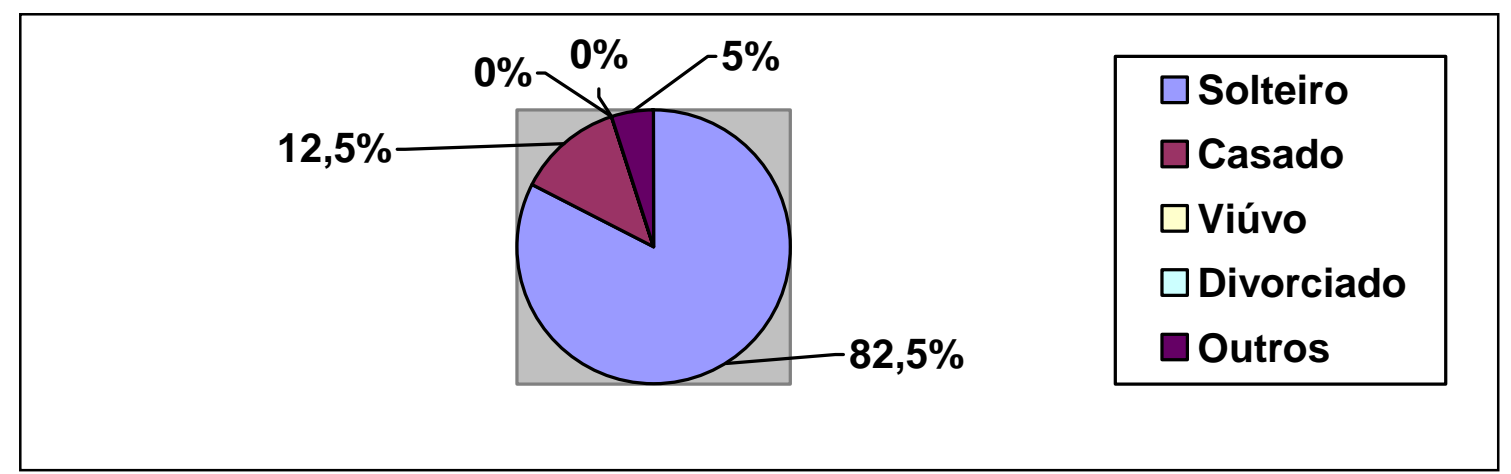

Fonte: Oliveira, Alyne. A partir de dados coletados em trabalho de campo de março a maio de 2005.

Comentários: Nota-se que a maioria dos praticantes do RPG são solteiros, o que corresponde a $82,5 \%$ do entrevistados. Apenas 12,5\% declararam ser casado, 5\% declaram estar em situação diferente da dos anteriores. Não se observou entre os entrevistados qualquer outra situação quanto ao estado civil.

Questão 4 - Faixa etária: 
TABELA D - Faixa Etária

\begin{tabular}{ccc}
\hline Faixa Etária & $\mathrm{N}^{\circ}$ de Respostas & Percentual \\
\hline 12 a 19 anos & 11 & $27,5 \%$ \\
20 a 29 anos & 25 & $62,5 \%$ \\
30 a 39 anos & 04 & $10 \%$ \\
40 a 49 anos & 00 & $0 \%$ \\
50 a 59 anos & 00 & $0 \%$ \\
Acima de 60 anos & 00 & $0 \%$ \\
\hline Total & 40 & $100 \%$ \\
\hline
\end{tabular}

Fonte: Oliveira, Alyne. A partir de dados coletados em trabalho de campo de março a maio de 2005.

\section{GRÁFICO D - Faixa Etária}

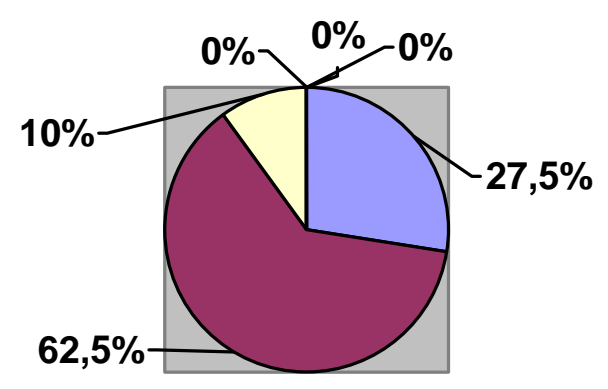

12 a 19 anos

$\square 20$ a 29 anos

$\square 30$ a 39 anos

$\square 40$ a 49 anos

50 a 59 anos

$\square$ acima de 60 anos

Fonte: Oliveira, Alyne. A partir de dados coletados em trabalho de campo de março a maio de 2005.

Comentário: Aqui se denota que a predominância é de jovens entre 20 e 29 anos praticando o RPG, nesse caso, alcançando o número de 62,5\%. O menor número diz respeito ao grupo de pessoas com idade entre 30 e 39 anos, sendo 10\% do total, ainda há que se observar a existência de um número significativo de praticantes entre os 12 e 19 anos de idade que praticam o RPG, chegando ao número de $27,5 \%$ do total.

Questão 5- Grau de escolaridade: 
TABELA E - Grau de Escolaridade

\begin{tabular}{ccc}
\hline Grau de escolaridade & $\mathrm{N}^{\circ}$ de respostas & Percentual \\
\hline $1^{\circ}$ grau incompleto & 00 & $0 \%$ \\
$1^{\circ}$ grau completo & 00 & $0 \%$ \\
$2^{\circ}$ incompleto & 08 & $20 \%$ \\
$2^{\circ}$ completo & 12 & $30 \%$ \\
Superior Incompleto & 14 & $35 \%$ \\
Superior Completo & 06 & $15 \%$ \\
\hline Total & 40 & $100 \%$ \\
\hline
\end{tabular}

Fonte: Oliveira, Alyne. A partir de dados coletados em trabalho de campo de março a maio de 2005.

GRÁFICO E - Grau de Escolaridade

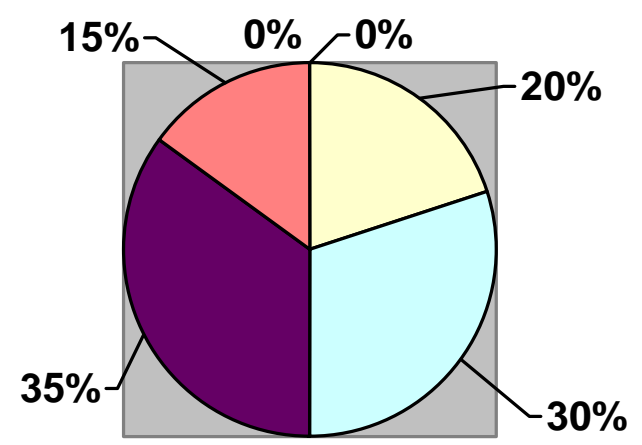

$\square 1^{\circ}$ grau incompleto

$\square 1^{\circ}$ grau incompleto

$\square 2^{\circ}$ grau incompleto

$\square 2^{\circ}$ grau completo

Superior incompleto

$\square$ Superior completo

Fonte: Oliveira, Alyne. A partir de dados coletados em trabalho de campo de março a maio de 2005.

Comentário: Observa-se que a maioria dos praticantes de RPG estão com escolaridade no nível superior incompleto atingindo 35\% do total, 15\% já completaram o nível superior e $30 \%$ já completaram o $2^{\circ}$ grau. Há ainda $20 \%$ cursando o $2^{\circ}$ grau e não foi observado nenhum praticante com escolaridade abaixo deste nível. 
Questão 6 - Ocupação Atual:

TABELA F - Ocupação Atual

\begin{tabular}{ccc}
\hline Ocupação Atual & $\mathrm{N}^{0}$ de respostas & Percentual \\
\hline Estudante & 21 & $50 \%$ \\
Motorista & 01 & $2,3 \%$ \\
Programador & 01 & $2,3 \%$ \\
Estagiário & 01 & $2,3 \%$ \\
Gerente de escola & 01 & $2,3 \%$ \\
Auxiliar Escritório & 02 & $4,6 \%$ \\
Pesquisador & 02 & $4,6 \%$ \\
Professor & 03 & $6,9 \%$ \\
Assessor Parlamentar & 01 & $2,3 \%$ \\
Advogado & 01 & $2,3 \%$ \\
Militar & 02 & $4,6 \%$ \\
Atendente & 01 & $2,3 \%$ \\
Trabalho & 01 & $2,3 \%$ \\
Vendedor & 02 & $4,6 \%$ \\
Nenhuma ocupação & 02 & $2,3 \%$ \\
\hline Total & $42^{2}$ & $100 \%$
\end{tabular}

Fonte: Oliveira, Alyne. A partir de dados coletados em trabalho de campo de março a maio de 2005.

GRÁFICO F - Ocupação atual

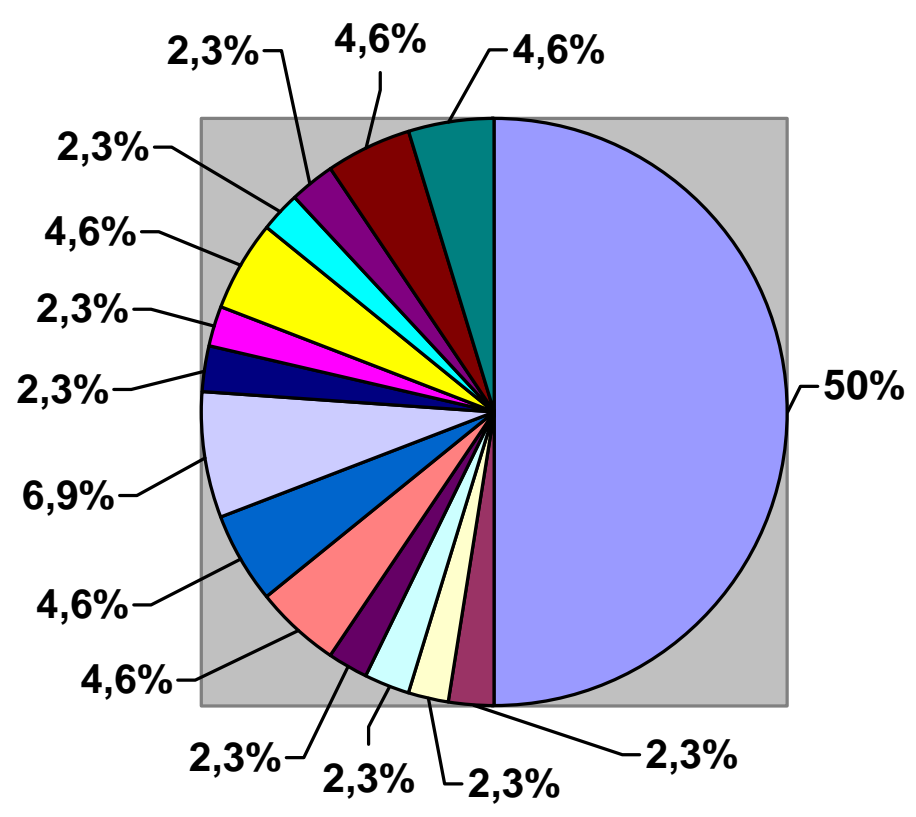

\begin{tabular}{|l|}
\hline$\square$ Estudante \\
$\square$ Motorista \\
$\square$ Programador \\
$\square$ Estágiario \\
$\square$ Gerente de escola \\
$\square$ Auxiliar escritório \\
$\square$ Pesquisador \\
$\square$ Professor \\
$\square$ Assessor Parlamentar \\
$\square$ Advogado \\
$\square$ Militar \\
$\square$ Atendente \\
$\square$ Trabalho \\
$\square$ Vendedor \\
$\square$ Nenhuma ocupação \\
\hline
\end{tabular}

Fonte: Oliveira, Alyne. A partir de dados coletados em trabalho de campo de março a maio de 2005.

${ }^{2} \mathrm{O}$ total das respostas diverge do número de questionários aplicados pelo fato de que esta questão foi aberta ao respondente obtendo assim por parte de alguns mais de um resultado. 
Comentário: É importante observar que alguns entrevistados responderam a questão com mais de uma respostas, ou seja, foi obtido um total de 42 informações, dentre elas $50 \%$ declararam-se estudantes. E apenas 4,6\% do entrevistados declararam-se desocupados. O outros 45,4\% das posições revelam que os jogadores possuem tipos de ocupações profissionais distintas.

Questão 8 - Duração das sessões de jogos:

TABELA G - duração das sessões de jogos

\begin{tabular}{ccc}
\hline Duração das sessões & $\mathrm{N}^{\mathrm{o}}$ de respostas & Percentual \\
\hline 1 hora & 0 & $0 \%$ \\
2 horas & 0 & $0 \%$ \\
3 horas & 05 & $12,5 \%$ \\
4 horas & 16 & $40 \%$ \\
5 horas & 8 & $20 \%$ \\
6 horas ou mais & 10 & $25 \%$ \\
Não respondeu & 01 & $2,5 \%$ \\
\hline Total & 40 & $100 \%$ \\
\hline
\end{tabular}

Fonte: Oliveira, Alyne. A partir de dados coletados em trabalho de campo de março a maio de 2005.

GRÁFICO G - Duração das sessões de jogos

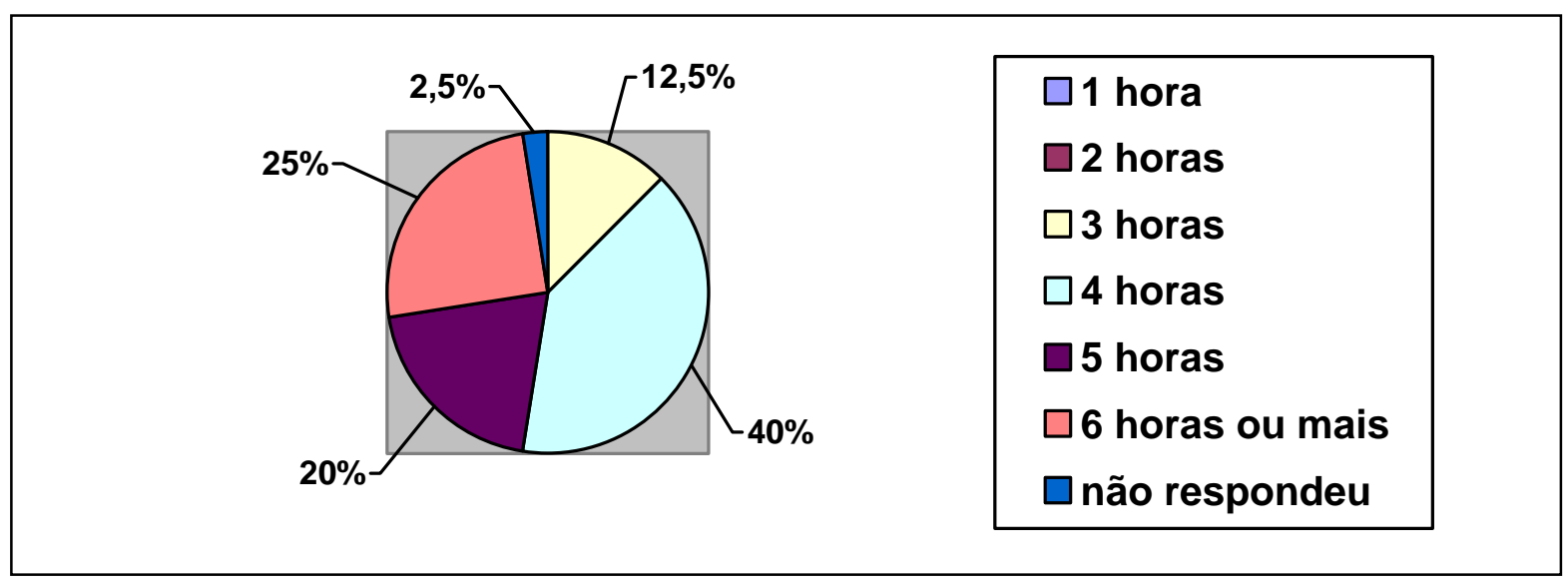


Fonte: Oliveira, Alyne. A partir de dados coletados em trabalho de campo de março a maio de 2005.

Comentário: Foi possível notar que os praticantes de RPG dispensam um tempo relativamente grande a prática dos jogos, com cerca de $40 \%$ dos entrevistados declarando que a duração das partidas de jogos demoram cerca de 4 horas, seguido de $25 \%$ que destinam 6 horas ou mais de seu tempo para esta atividade e de 20\% que passam uma média de 5 horas dedicados à mesma.

Questão 9 - Freqüência de jogos:

TABELA H - Freqüência de jogos semanais

\begin{tabular}{ccc}
\hline Freqüência jogos semanais & $\mathrm{N}^{\circ}$ de respostas & Percentual \\
\hline 1 vez & 25 & $62,5 \%$ \\
2 vezes & 11 & $27,5 \%$ \\
3 vezes & 2 & $5 \%$ \\
4 vezes & 1 & $2,5 \%$ \\
5 vezes ou mais & 1 & $2,5 \%$ \\
\hline Total & 40 & $100 \%$ \\
\hline
\end{tabular}

Fonte: Oliveira, Alyne. A partir de dados coletados em trabalho de campo de março a maio de 2005.

GRÁFICO H - Freqüência de jogos semanais

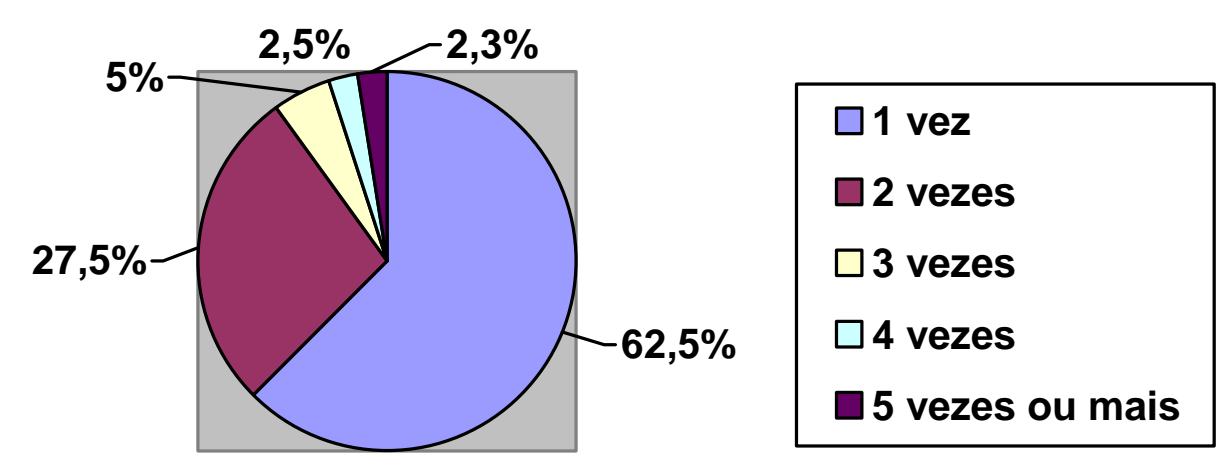

Fonte: Oliveira, Alyne. A partir de dados coletados em trabalho de campo de março a maio de 2005. 
Comentário: É possível notar que 62,5\% dos entrevistados, ou seja, mais da metade, dedicam-se pelo menos uma vez por semana ao RPG. Já 27,5\% se dedicam, ao mesmo, pelo menos duas vezes por semana. Sendo que o restante costuma jogar 3 vezes ou mais, destinando boa parte do seu tempo ao Role Playing Game.

Questão 10 - Quantidade de pessoas com quem jogam:

TABELA I - Quantidade de pessoas com quem jogam

\begin{tabular}{ccc}
\hline Quantidade de pessoas & $\mathrm{N}^{\circ}$ de pessoas & Percentual \\
\hline 1 pessoa & 0 & $0 \%$ \\
2 pessoas & 0 & $0 \%$ \\
3 pessoas & 5 & $12,5 \%$ \\
4 pessoas & 12 & $30 \%$ \\
5 pessoas & 6 & $15 \%$ \\
6 pessoas ou mais & 16 & $40 \%$ \\
Não respondeu & 1 & $2,5 \%$ \\
\hline Total & 40 & $100 \%$ \\
\hline
\end{tabular}

Fonte: Oliveira, Alyne. A partir de dados coletados em trabalho de campo de março a maio de 2005.

GRÁFICO I - Quantidade de pessoas com quem jogam

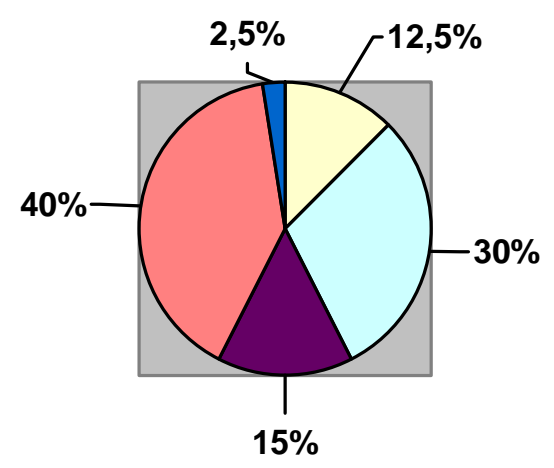

\begin{tabular}{|l|}
\hline$\square 1$ pessoa \\
$\square 2$ pessoas \\
$\square 3$ pessoas \\
$\square 4$ pessoas \\
$\square 5$ pessoas \\
$\square 6$ pessoas ou mais \\
$\square$ Não respondeu \\
\hline
\end{tabular}


Fonte: Oliveira, Alyne. A partir de dados coletados em trabalho de campo de março a maio de 2005.

Comentário: Foi possível perceber que a grande maioria, 40\% das repostas, respondeu que geralmente costuma jogar com 6 ou mais pessoas, porém durante a aplicação dos questionários notou-se que a maioria dos que responderam jogar com mais de 6 ou mais pessoas também estavam no SESC da 504 sul, sendo assim, ficou claro uma relação entre o local de aplicação do questionário e o tipo de jogador, ou seja, o SESC é conhecido com ser um local de encontro do Brasília By Night e este grupo está totalmente voltado para a realização de jogos de live actions que sempre duram mais de 4 horas e comportam cerca de 15 a vinte pessoas.

Questão 11 - Envolvimento com organização ou projeto relacionado ao RPG

TABELA J - Envolvimento com organização ou projeto relacionado ao RPG

\begin{tabular}{ccc}
\hline Organização & No $^{o}$ de respostas & percentual \\
\hline BBN (Brasil By Night) & 18 & $51,4 \%$ \\
OWBN (One World By Night) & 1 & $2,8 \%$ \\
White Wolf - After life & 1 & $2,8 \%$ \\
Live Garou & 1 & $2,8 \%$ \\
Rage Across & 6 & $17,1 \%$ \\
Live Sabá & 1 & $2,8 \%$ \\
Alvorecer do IPÊ & 1 & $2,8 \%$ \\
Org. do Encontro de RPG - Pátio Brasil Shopping & 1 & $2,8 \%$ \\
Otaku Sentai & 2 & $5,7 \%$ \\
Brasil D20 & 1 & $2,8 \%$ \\
Lista Tormenta & 1 & $2,8 \%$ \\
Lista ação & 1 & $2,8 \%$ \\
\hline
\end{tabular}


Fonte: Oliveira, Alyne. A partir de dados coletados em trabalho de campo de março a maio de 2005.

GRÁFICO J - Envolvimento com organização ou projeto relacionado ao RPG

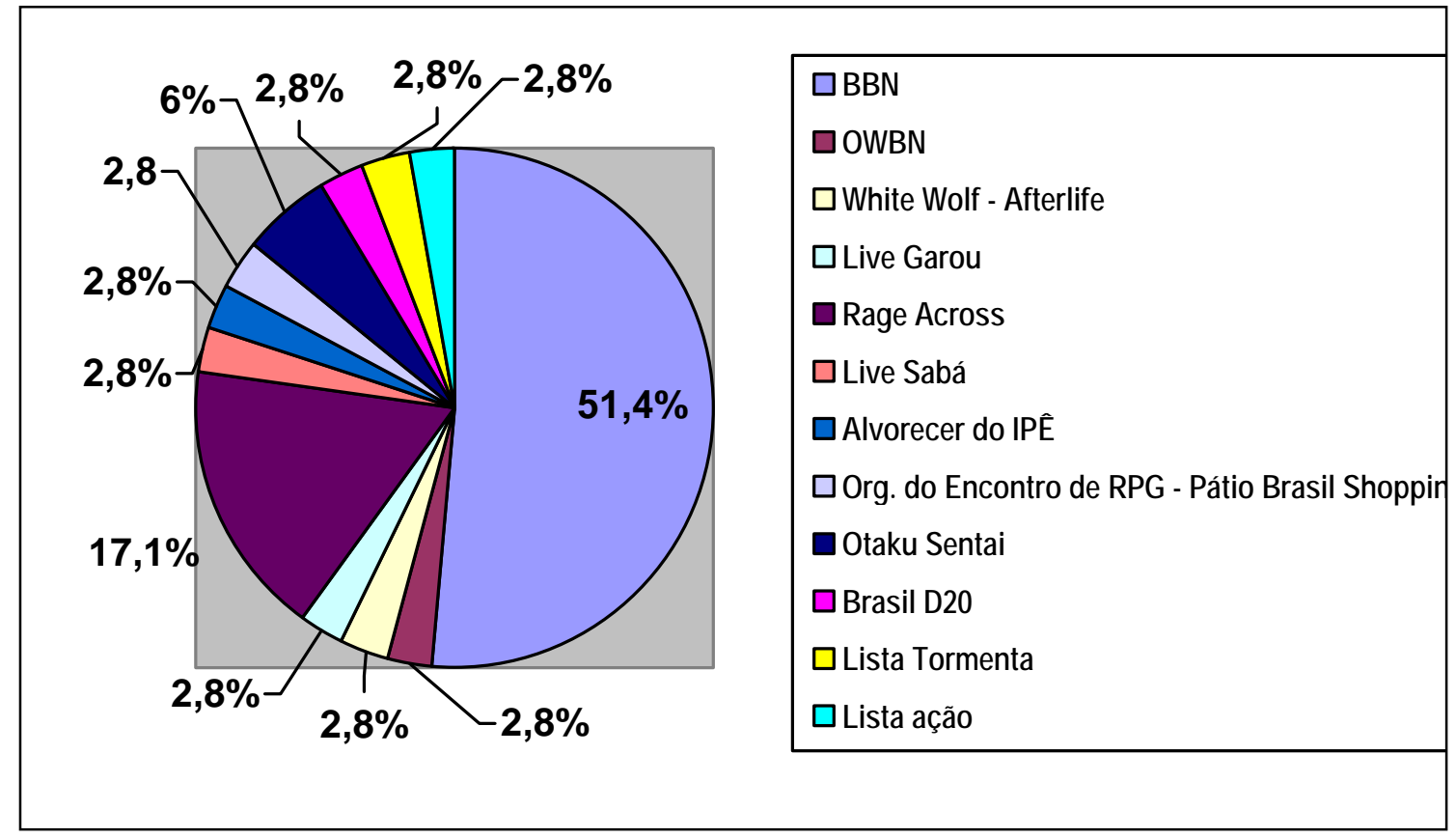

Fonte: Oliveira, Alyne. A partir de dados coletados em trabalho de campo de março a maio de 2005.

Comentário: observa-se que a maioria dos entrevistados fazem parte da organização Brasil By nyght, 51,4\% das respostas. Talvez devido ao fato desta ser a mais antiga organização a promover jogos em Brasília. O restante das respostas foram distribuídas entre as mais diversas organizações e projetos que estão espelhados pelas cidades.

Questão 12 - Nível de importância do RPG

TABELA L - Nível de importância do RPG

\begin{tabular}{ccc}
\hline Nível de importância do RPG & $\mathrm{N}^{\mathrm{o}}$ de respostas & Percentual \\
\hline Nenhuma & 0 & $0 \%$ \\
\hline
\end{tabular}

\footnotetext{
${ }^{3} \mathrm{O}$ total das respostas diverge do número de questionários aplicados pelo fato de que esta questão foi aberta ao respondente sendo que alguns destes não a refutou, assim foram tabulados apenas os resultados fornecidos.
} 


\begin{tabular}{ccc}
\hline Pouca & 4 & $10 \%$ \\
Média & 10 & $25 \%$ \\
Grande & 11 & $27,5 \%$ \\
Muito grande & 8 & $20 \%$ \\
Extremamente importante & 7 & $17,5 \%$ \\
\hline Total & 40 & $100 \%$ \\
\hline
\end{tabular}

Fonte: Oliveira, Alyne. A partir de dados coletados em trabalho de campo de março a maio de 2005.

GRÁFICO L - Nível de Importância do RPG

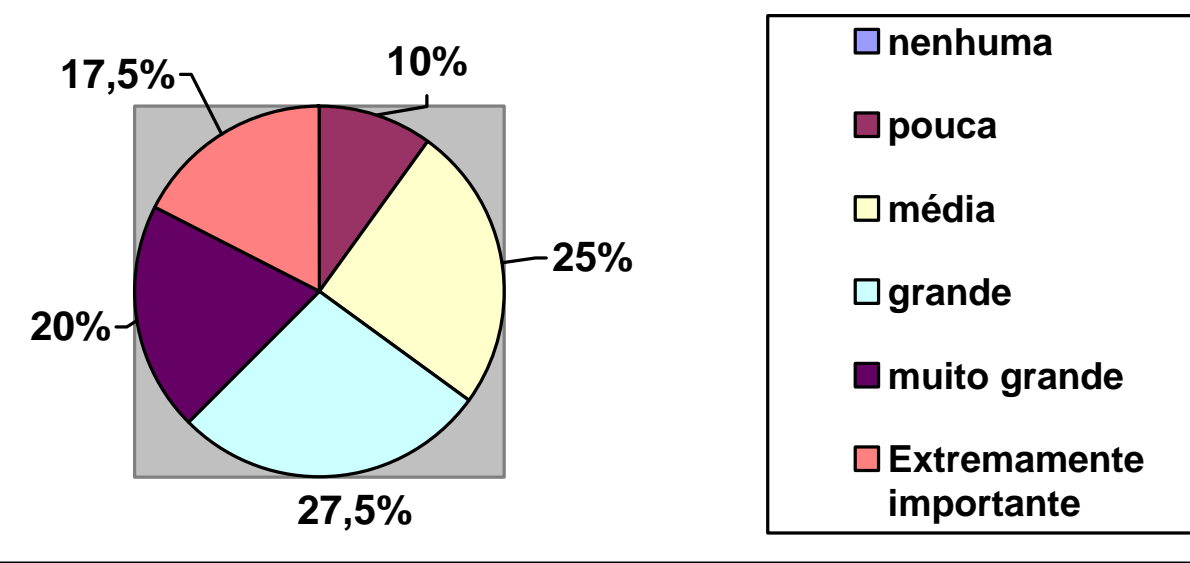

Fonte: Oliveira, Alyne. A partir de dados coletados em trabalho de campo de março a maio de 2005.

Comentário: Observa-se que a importância do RPG para seus praticantes é bem distribuídas, muitos consideram o jogo com uma importância média, ou seja, 25\% dos entrevistados. Um grupo considerável, que atinge a porcentagem de 27,5, afirmam que sua importância é grande, já 20\% consideram que o jogo tem uma importância muito grande na sua vida. Apenas 10\% responderam que o RPG tem pouca importância. 
Questão 13 - Motivações para jogar RPG

TABELA M - Motivação para jogar RPG

\begin{tabular}{ccc}
\hline Motivações para jogar RPG & N $^{\circ}$ de respostas & Percentual \\
\hline Por causa dos filhos & 2 & $3,2 \%$ \\
Para acompanhar namorado & 1 & $1,6 \%$ \\
Representar um papel / fazer alguma coisa & 5 & $8 \%$ \\
Por que é bom / saudável / seguro / legal / divertido / & 21 & $33,6 \%$ \\
prazeroso / passatempo & 12 & \\
Para conhecer novas coisas ou pessoas & 9 & $19,2 \%$ \\
Estimular a imaginação / criatividade / percepção / & & $14,4 \%$ \\
raciocínio & 1 & $1,6 \%$ \\
Posto pela aventura / ação / combate & 2 & $3,2 \%$ \\
Para aliviar tensãos / narrativas & 6 & $9,6 \%$ \\
Por que RPG comanda & 1 & $1,6 \%$ \\
\hline Total & 1 & $1,6 \%$ \\
\hline
\end{tabular}

Fonte: Oliveira, Alyne. A partir de dados coletados em trabalho de campo de março a maio de 2005.

${ }^{4} \mathrm{O}$ total das respostas diverge do número de questionários aplicados pelo fato de que esta questão foi aberta ao respondente obtendo assim por parte de alguns mais de um resultado. 
GRÁFICO M - Motivação para jogar RPG

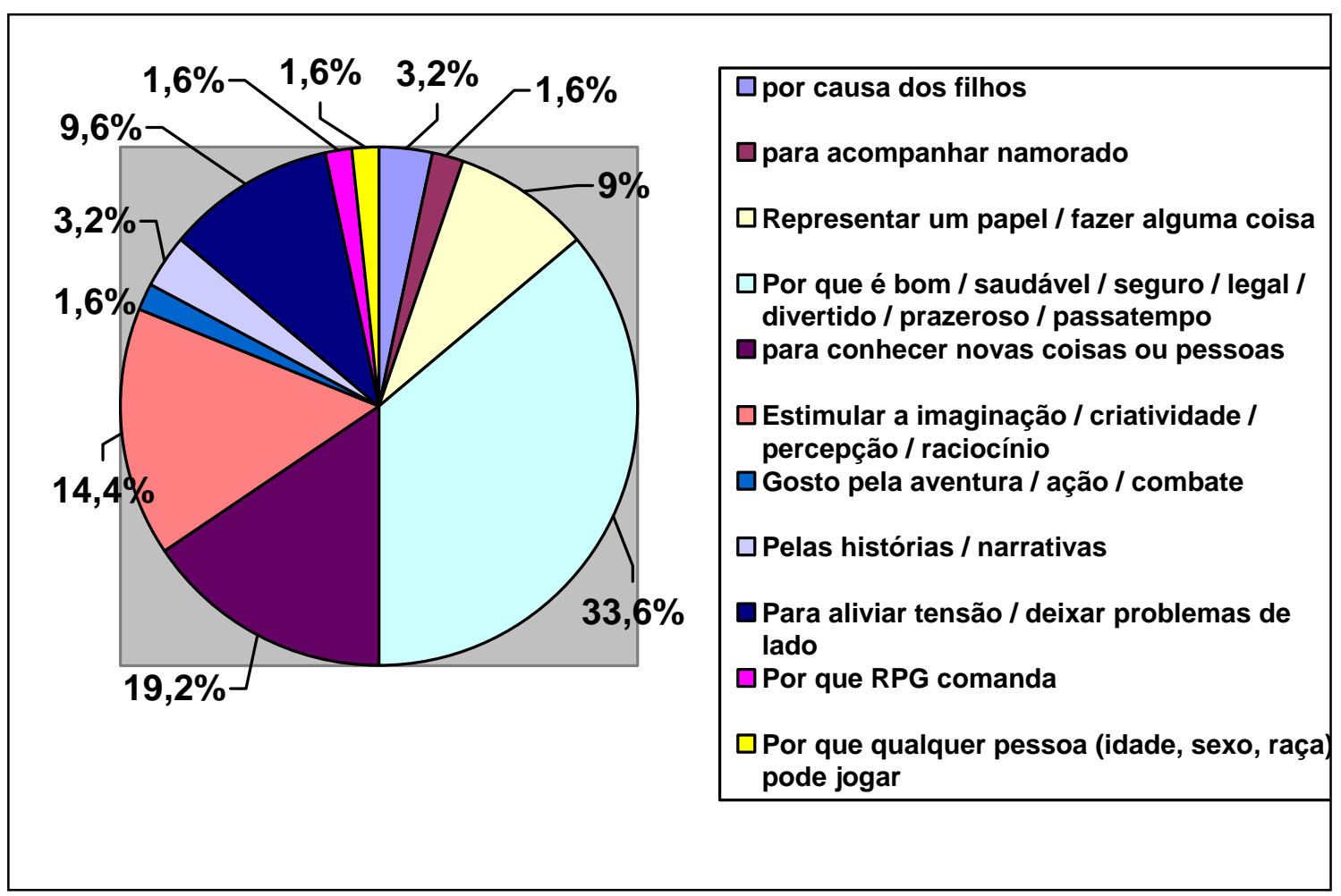

Fonte: Oliveira, Alyne. A partir de dados coletados em trabalho de campo de março a maio de 2005.

Comentário: observa-se que as maiores motivações para os jogadores são o prazer, a diversão, a segurança que o jogo proporciona, com 33,6\% das respostas. Outro ponto que chama a atenção é a quantidade de resposta de estimulo a imaginação, criatividade, 
percepção e raciocínio que motivam os jogadores, que é de $14,4 \%$ das respostas. Nota-se a presença de 19,2\% das respostas como sendo motivação para o jogo o fato de conhecer novas pessoas.

\subsection{Observação in loco}

Apresentação dos dados referentes à observação das sessões de jogos realizadas, com o objetivo de verificar como se dá a formação dos grupos, a sua comunicação e seus interesses comuns, quais são suas atividades, temas e discussões freqüentes. Buscando ainda observar o comportamento do praticante de RPG no local em que joga e como se dão as relações sociais nesse meio.

Foram observados três grupos: o primeiro deles nos dias 12 e 19 de fevereiro de 2005, composto por 5 jogadores; o segundo no dia 26 de fevereiro de 2005 e 5 de março de 2005, composto por 5 pessoas; e o terceiro no dia 12 e 19 de março de 2005, composto por 7 pessoas, frisando que todas essas datas foram sábados.

Durante a observação dos grupos percebe-se que sempre há uma organização, sempre há o mestre que conduz o jogo, e os demais jogadores sentam-se em uma mesa em volta deste. Há alguns jogadores que são levados mais a sério em suas opiniões devido ao tempo em que jogam e outros que não são considerados muito importante para o grupo, talvez pelo fato de não jogarem a muito tempo ou não levarem a sério o jogo. Quase sempre o horário é predeterminado, e atrasos não são bem vistos.

Notou-se que a regularidade dos jogos é muito importante, dá ao grupo a noção de que estão progredindo dentro de uma história e permite a continuidade do mesmo. Os jogos, geralmente, ocorrem pelo menos uma vez por semana, porém através de pesquisas anteriores notou-se que esta freqüência pode variar, sendo que muitas vezes, alguns grupos, principalmente quando seus componentes são adultos, costumam passar o fim de 
semana, inclusive virando as noites, dedicando-se à prática do jogo, em especial o live action.

O narrador/mestre inicia as partidas com algumas informações e tenta recapitular quais foram as últimas atitudes e ações dos personagens dos jogadores. Após as informações iniciais dadas, os jogadores vão aos poucos retomando suas ações de onde pararam, e com isso vão sendo levados para dentro do jogo onde antes tinham parado. As interrupções desnecessárias não são bem aceitas pelos membros do grupo, pois para eles hora de jogar é hora de jogar, qualquer outro fator externo que atrapalhe o andamento do jogo torna-se um incomodo para muitos deles, que em poucos minutos ficam irritados e querem continuar logo o jogo.

Quando o grupo é composto por 5 ou mais pessoas é exigido de todos os jogadores um pouco mais de paciência do que o normal para as partidas de RPG, devido ao fato de muitas pessoas estarem jogando, cada um tem que esperar a vez do outro para poder continuar suas ações, e dependendo do que o personagem estiver fazendo, uma ação pode levar vários minutos para ser completada.

Para finalizar, os jogadores sempre anotam o estado em que se encontra o seu personagem, o que ele ganhou ou perdeu, fatos importantes e pistas para resolver os problemas propostos pelo mestre/narrador, se os jogadores conseguirem alcançar os objetivos colocados a sua frente, no final recebem "recompensas”, “tesouros”, “dinheiro” e mais “poderes” para melhorar as técnicas de seus personagens.

Outro momento observado foi uma das "partidas" do jogo conhecida como In Game, ou seja, momentos em que assuntos relevantes ao desenvolvimento da história do Live Action, devem ser solucionados. Para melhor compreender: o Live Action, é como uma festa ou reunião de vampiros, neste caso do grupo observado, por um motivo qualquer, e que acontece geralmente uma vez por mês. Durante o mesmo acontecem confraternizações, confabulações, enfim tenta-se imitar uma reunião comum a que se conhece, porém, atitudes e decisões tomadas naquele instante podem ter conseqüências em outros momentos da "vida" dos personagens, assim existe a necessidade de se encontrar para desenvolver essas histórias, o que é chamado de In Game.

Os jogadores observados pertencem ao grupo Brasília by nigth, conhecido como BBN. Este talvez seja o grupo mais estruturado do país, tendo organização Internaciona, nacional e regional. E que apesar de não possuir um registro de seus jogadores já possui 
um número muito maior adeptos que a quantidade de jogadores na Europa, diz o excoordenador do grupo em Brasília, Bruno Benitz que ainda exercia o cargo na data em que foi feita esta pesquisa, ou seja, 31 de março de 2005.

Pode-se observar que neste encontro não há regras tão rigorosas quanto à postura do jogador como dentro do Live Action, na maior parte do tempo os mesmos conversam e brincam não tendo o compromisso de realizar alguma ação que seja e só tendo alguma atitude em determinados momentos quando era atraído por um dos condutores do jogo ou por um outro jogador.

Assim se alguém quisesse resolver alguma cena que tinha sido interrompida ou que precisasse ser continuada convocava o "mestre” (condutor do jogo), o (s) jogador (s) que interpreta o personagem com quem ele que interagir e geralmente dizia: “- vamos rolar um 'in' agora”. Neste momento todos os envolvidos começavam a se comportar, a falar e utilizar alguns gestos do jogo que determinam certas ações, como se fossem os seus personagens e com a mesma naturalidade que o "in" começava ele terminava, e os jogadores voltavam a ter atitudes normais. Nesses momentos, com alguma freqüência, surgia dúvidas sobre o jogo e suas regras, sendo que algumas ações não eram previstas em nenhum dos livros ou suplementos de posse dos praticantes, neste caso, os jogadores mais experientes davam a sua opinião e muitas vezes tinham a palavra final.

Além disso, percebeu-se a estreita relação de amizade entre os jogadores, sendo que as conversas sobre o jogo e seus personagens eram intensas e continuadas, e eles se tratavam com muita intimidade, utilizando-se inclusive de apelidos, a maioria deles referentes ao jogo isto quando não era o nome de algum personagem com o qual o individuo chamado joga ou costuma jogar.

Notou-se a presença de alguns indivíduos que não foram para participar da “partida”, e pelas informações levantadas pode-se descobrir que um pequeno grupo era apenas de curiosos e o restante era formado de ex-jogadores ou jogadores de outros grupos que foram ali para reencontrar amigos de jogos ou apenas para "bater papo”.

Os jogos aconteciam alternadamente às conversas, para quem não conhece, provavelmente, ficaria difícil de distinguir jogo de realidade. Fato que para eles parecia normal, e todos compreendiam o que era momento de jogo e o que não era, além do que algum gestos feitos pelo jogador, que indicam estar utilizando alguma habilidade do seu 
personagem, e que é bem conhecido pelos praticantes, ajudava a determinar estes tempos de estar no jogo ou não.

\section{INTERPRETAÇÃO DOS DADOS}

Por meio das observações, aplicação de questionários e das entrevistas realizadas foi possível perceber a importância do RPG para seus praticantes e traçar um perfil dos jogadores desta atividade recreativa.

Logo é possível notar que a maioria dos jogadores de RPG de Brasília são estudantes que estão concluindo ou já concluíram o nível superior, são ainda em grande parte solteiros, do sexo masculino, estão na faixa etária entre 20 e 29 anos, jogam pelo menos uma vez por semana, com pelo menos 5 pessoas e dedicam cerca de 4 a 5 horas do seu tempo para o jogo.

Muitos praticantes, talvez a maior parte deles, gostam de ouvir músicas do estilo rock ' $\mathrm{n}$ roll, outros muitos gostam de vestir-se de preto, ou seja, fazer um estilo neo-gótico e quase todos conhecem e praticam mais de um sistema ou cenário de regras para o RPG.

Muitos destes fazem parte de alguma organização ou projeto relacionado ao jogo, quase sempre uma organização voltada para a realização de live actions, os jogos com ação ao vivo, onde os jogadores realmente interpretam seus personagens como num teatro improvisado, e nesta prática nota-se uma grande dedicação dos mesmos, eles se vestem, se comportam, falam e tentam agir ao máximo como seus personagens.

Para a grande maioria dos praticantes, o jogo, tem uma grande influência em suas vidas começando pelas relações sociais, construídas em torno do jogo e que duram após o 
termino dele, podendo também ocorrer quando param de jogar ou quando não jogarem mais com a mesma freqüência. Aqueles jogadores mais antigos, que geralmente são os mestres condutores de jogos, são, na maioria das vezes, muito bem vistos pelos novos jogadores, e suas opiniões com relação ao jogo são levadas em consideração quando há algum impasse sobre as regras ou detalhes de algum cenário de jogo.

É possível ainda destacar algumas informações relevantes e curiosas com os resultados dos questionários, como por exemplo, o fato de que entre as 16 pessoas que responderam que costumam jogar com seis pessoa ou mais, 13 delas estavam no SESC, local conhecido por ser ponto de encontros e reuniões entre os jogadores de live action de Brasília. Outro detalhe interessante é que: das quatro pessoas que responderam o questionário, e se encontram na faixa etária entre 30 e 39 anos, 3 delas possuem nível superior completo, mais uma evidência de que a formação cultural faz parte do perfil comum do jogador de RPG.

Há outras respostas, que muito revelam a respeito da motivação dos jogadores para a prática do RPG, dentre elas se destacam: o poder de representar qualquer papel ou de fazer qualquer coisa; os detalhes de ser o jogo bom, saudável, seguro, legal, divertido, prazeroso, e um passatempo; a questão de que através dele é possível alimentar um círculo social de amizades; a possibilidade de se conhecer novas coisas ou pessoas; a sua propriedade de estimular a imaginação, a criatividade, a percepção e o raciocínio; o gosto pela aventura, ação; combates; as variadas opções em histórias e narrativas; e a resposta mais interessante delas: para aliviar a tensão e deixar problemas de lado.

Um detalhe chama atenção: a prática da atividade faz com que os jogadores interessem-se mais pela literatura e pela história em geral, tanto que observou-se nas mesas de jogos e nos In Games uma quantidade relativamente grande de livros sendo utilizados pelos mesmos. Tudo isso devido ao fato de que os jogadores necessitam de ler os livros para entender os jogos e também às vezes necessitam buscar fontes de fatos 
históricos para construir histórias e personagens fiéis a lógica do jogo e do cenário em que se passa, fiéis a realidade de um determinado local, cidade ou país.

\section{TESTE DA HIPOTESE}

Hipótese 1: O jogo é mais popular entre os jovens, que geralmente possuem experiências pessoais e características culturais em comum, e disponibilizam de tempo e dedicação para a atividades relacionadas ao jogo, tendo, quase sempre, sua vida pessoal e social influenciada e/ou afetada pela prática do jogo.

Está hipótese foi confirmada. Por meio das respostas dos questionários, das entrevistas realizadas e das observações, foi possível perceber que a grande maioria dos jogadores possui características em comum, sendo que o perfil traçado é em grande parte de jovens que possuem de tempo para se dedicar há alguma atividade que demande dedicação e tempo e neste caso o fazem com o RPG.

As características pessoais e culturais em comum são facilmente perceptíveis entre os jogadores devido ao fato de que eles, em sua grande maioria, possuem as mesmas 
motivações para praticarem o RPG, conforme foi possível constatar nos resultados dos questionários aplicados durante a elaboração do estudo. A busca pelo prazer, a diversão e a segurança que o jogo proporciona são os motivos que os levam a jogar.

A semelhança cultural, intelectual e social entre os praticantes é inegável, quase todos possuem a mesma faixa etária, o mesmo nível de escolaridade e preferências em comum. A preferência musical é o mais evidente, muitos destes utilizam camisetas de bandas de rock. Outros também gostam de tatuar os corpos com figuras que relembram os temas dos jogos e outros gostam de utilizar brincos e piercings.

As necessidades de compensação e de um meio para evasão das pressões sofridas são supridas pela prática do jogo, e isso se mostra claro, a partir do momento em que analisando respostas que foram obtidas nos questionários aplicados às pessoas praticantes do jogo, as mesmas revelam motivações como: “exercitar a imaginação, possibilidade de criação de narrativas, sublimação de tensões psicológicas, diversão, desenvolvimento e cultivo de circulo social, estimula a percepção e o raciocínio rápido, obtenção de novos conhecimentos, projeção do ego e da fantasia para um cenário imaginário, fuga do cotidiano, quebrar a lógica, busca pela aventura.” Assim apresentam-se algumas defesas a favor deste jogo, que tentam mostrar suas propriedades de recreação aliadas ao desenvolvimento cultural e alívio de tensões daqueles que o praticam.

Devido ao tempo em que os jogadores dispensam para a prática dos jogos, a freqüência destes, o envolvimento com organizações que buscam promover os jogos e o nível de importância dado ao RPG pelos praticantes é muito evidente as influências deste em suas vida. A disponibilidade de tempo também é muito importante para caracterizar o jogador de RPG. Conforme pode se perceber das respostas da questão $\mathrm{n}^{\circ} 8$ do questionário, a maioria dos entrevistados declarou que as partidas duram em média cerca de 4 horas, ou seja, estes jogadores dispõem de um tempo para poder jogar e conseqüentemente acabam dedicando parte do tempo em que estão liberados das suas obrigações diárias, fato este que demonstra que os praticantes, em sua maioria, de alguma forma, têm sua vida pessoal e social influenciada pela prática do jogo.

Não foi possível saber se essa influência é de certa forma boa ou ruim para o jogador. Porém, é fácil notar entre as respostas dos entrevistados que a maioria considera o RPG como um passatempo, um hobby como outro qualquer e que seu principal objetivo é 
a diversão, também sendo considerado como um ótimo meio pelo qual pode-se conhecer novas pessoas e obter mais conhecimentos e cultura em geral.

\section{CONCLUSÃO}

Ao final desta pesquisa conclui-se que a prática do Role Playing Game vem crescendo dentro do meio juvenil e que os jogadores possuem características psicológicas e sociais semelhantes.

Ao analisar as informações coletadas foi possível perceber o papel fundamental que o RPG emprega na vida e no meio social de seus praticantes, não só entre os que jogam, mas também entre os que se profissionalizaram através deste.

As empresas voltadas para este tipo de jogo estão cada vez mais interessadas em produzir e comercializar seus produtos e livros. O crescimento mercadológico é de fácil notabilidade e através desta pesquisa foi possível perceber que há pelo menos dez anos 
não haviam tantos sites na internet voltados para este jogo, tantas lojas especializadas no tema e que a maioria dos jogadores atuais nem conheciam o RPG.

Foi possível traçar um perfil para o jogador de RPG, pois este quase sempre está estudando, seja no nível médio ou superior, é jovem, dispõem de tempo, dedica-se ao jogo, a maioria é do sexo masculino e considera o jogo como um fato importante na sua vida. A maioria de seus amigos também jogam RPG e quase sempre possuem os mesmos interesses pessoais pela prática deste e de outras atividades.

Importante frisar que foi possível detectar que entre a faixa etária dos jogadores que estão entre os 12 e 19 anos, há 1 que já está cursando o nível superior, 2 que estão concluindo o segundo grau e 8 já possuem o segundo grau completo, ou seja, o nível escolar dos adolescentes que praticam o RPG está na média ou até mesmo superior ao padrão normal de escolaridade esperada para os jovens nesta faixa etária, mais uma evidencia de que há uma estreita relação entre o desenvolvimento cultural e o RPG, sendo provável que isto também acabe por se transformar numa característica em comum a todos e até mesmo necessária para o desenvolvimento das relações interpessoais que desdobramse em amizades e na formação de grupos (tribos). O que talvez seja uma forma de compensar uma problemática típica de Brasília que é o convívio social distanciado.

É importante estabelecer a relação entre o jogo e o que o mesmo proporciona, ou seja, diversão, prazer, estimulo a criatividade, imaginação e raciocínio. Além disso, é notável a quantidade de jogadores que utilizando o RPG como uma válvula de escape, num processo de catarse que proporciona experiências intensas e ao mesmo de alívio e relaxamento. E isso acontece porque numa sociedade mecanicista e rotineira chega-se a ponto de exigir rupturas, mesmo que estas sejam imaginárias, porém tendo a capacidade de nelas projetar-se a si mesmo e a desejos íntimos podendo até mesmo realizá-los.

O fato dos jogadores se organizarem em grupo também leva a crer que as relações sociais, baseados no interesse pelo jogo, fazem com que os próprios jogadores se identifiquem como um grupo social especifico dentro da sociedade, possuindo interesses em comuns e objetivos coletivos a serem alcançados. O fato de possuírem uma linguagem apropriada para o mais fácil e rápido entendimento dos códigos e signos dos jogos também é um ponto decisivo na sua classificação como um grupo específico dentro da sociedade.

A apropriação de espaços públicos voltados para a prática é outra característica que faz com que os grupos de jogadores de RPG serem considerados pertencentes a uma 
tribo urbana, pois a exposição pública a sociedade demonstra que os jogadores querem ser vistos e reconhecidos como membros daquele grupo de indivíduos.

Portanto, este estudo termina, tentando demonstrar que o Role Playing Game têm um papel importante na formação cultural da juventude e que este jogo merece mais atenção por parte das mais diversas áreas da sociedade moderna, contudo, há que se notar que o RPG tornou-se uma importante ferramenta de recreação e divertimento para alguns jovens de Brasília não por causa de algum movimento social ou programa do Estado, e sim por que este desenvolveu-se e vai continuar se desenvolvendo em meio aqueles que procuram novas maneiras de se divertir e de conhecer novidades, característica particular daqueles que possuem um espírito jovem, interessados em buscar uma satisfação pessoal, buscando o prazer pessoal em diversos lugares e não tem medo em conhecer, experimentar e aproveitar aquilo esta sendo lhes apresentado pela primeira vez.

\section{SUGESTÕES}

Infelizmente, ficou claro que ainda existe no meio acadêmico brasileiro uma lacuna em relação a estudos sobre o RPG, são poucas as fontes de dados onde se pode buscar referencial teórico sobre o tema, dentre estas poucas se destaca o livro Roleplaying Game, de Sonia Rodrigues, ao qual sem este seria muito mais difícil a realização deste estudo.

Por este motivo, fica como sugestão a necessidade de que os mais diversos profissionais e estudiosos do meio acadêmico chamem para si a responsabilidade de estudar e descobrir quais são as características intrínsecas deste fenômeno cultural que está 
crescendo a cada dia mais nos centros urbanos de todo o mundo. Faz-se também necessário a elaboração de mais pesquisas em torno do jogador, dos seus objetivos e de suas motivações para praticar o jogo.

Muito ainda precisa ser pesquisado e analisado, na tentativa de se descobrir de que forma e como esta atividade atingiu a juventude que se organiza em torno do RPG. Seria muito importante um estudo que buscasse a fundo as origens da prática do jogo. As inspirações, fontes e motivos dos jogadores para a construção de personagens. Poderia também se construir uma pesquisa com intuito de melhor entender como se dá a formação dos grupos de jogos, suas relações interpessoais mais intrínsecas, sua relações com a família e as pessoas que não praticam o RPG. Tendo como enfoque o perfil psicológico dos praticantes do jogo.

\section{BIBLIOGRAFIA}

\subsection{Livros}

ADAMO, Fabio A. (org.). Juventude. Trabalho, Saúde e Educação. Rio de Janeiro: Forense-Universitária, 1987.

ABRAMOVAY, M., WAISELFISZ, J., ANDRADE, C., RUA, M. Gangues, galeras, chegados e rappers. Rio de Janeiro: Garamond, 1999. 
BACAL, Sarah. Lazer e o universo dos possíveis. São Paulo: Aleph, 2003.

BARSA PLANETA INTERNACIONAL. Grande Barsa CD Versão 4.0. São Paulo: Barsa Planeta Internacional, 2004. CD-ROM

CAMARGO, Luiz O. Lima. Educação para o lazer. São Paulo: Moderna, 1998.

DUMAZEDIER, Joffre. Lazer e cultura popular. 3ed. São Paulo: Perspectiva, 2000. . Novo Dicionário da Língua Portuguesa, $2^{\circ}$ ed. $28^{\circ}$ impressão. Rio de Janeiro: Nova Fronteira, 1986.

GAELZER, Lenea. Lazer: benção ou maldição? Porto Alegre: Sulina, 1979.

GIL, Antônio Carlos. Como elaborar projetos de pesquisa. 3ed. São Paulo: Atlas, 1991.

GOFFMAN, Erving. A representação do eu na vida cotidiana. Petrópolis: Vozes, 1985.

GRANDE ENCICLOPÉDIA BARSA. 3ed. São Paulo: Barsa Planeta Internacional, 2004, vl. 9.

3ed. São Paulo: Barsa Planeta Internacional, 2004, vl. 12. 3ed. São Paulo: Barsa Planeta Internacional, 2004, vl. 14.

GUERRA, Marlene. Recreação e Lazer. 5ed. Porto Alegre: Sagra, 1996

HUIZINGA, Johan. Homo ludens: o jogo como elemento da cultura. $2^{\circ}$ ed. Trad. João Paulo Monteiro. São Paulo: Perspectiva, 1980.

LAKATOS, E. M., MARCONI, M. A. Fundamentos de Metodologia Científica. 4 ed. São Paulo: Atlas, 2001.

LIMA, T. L. Manual básico para elaboração de Monografia. 3ed. Canoas: ULBRA, 1999.

MAFFESOLI, Michel. Transfiguracao do politico: A tribalizacao do mundo (a). Porto alegre: Sulina, 1997.

MARCELINO, Nelson Carvalho. Lazer e Educação. 2 ed. Campinas: Papirus, 1990.

MURTA, S. M., ALBANO, C. Interpretar o patrimônio: um exercício do olhar. Belo Horizonte: UFMG, Território Brasilis, 2002.

PERSON,. Ethel. O poder da fantasia: como construímos nossa vidas. Rio de Janeiro: Rocco, 1997.

PRETI, Dino. A linguagem Proibida. São Paulo: T. A. Queiroz, 1983.

RODRIGUES, Sonia. Roleplaying Game e a pedagogia da imaginação no Brasil. Rio de Janeiro: Bertrand, 2004.

ROSIU, O. P. O., PAULESCU, D., MUNIZ, A. J. O. Monografia - Brasília, 2003. 
SANT’ANA, Denise Bernuzzi. O prazer justificado. História e Lazer (São Paulo, 1969/1979). São Paulo: Marco Zero; Brasília: CNPq, 1994.

WAICHMAN, Pablo. Tempo livre e recreação um desafio pedagógico. Campinas: Papirus, 1997.

YÁZIGI, Eduardo. A alma do lugar. Turismo, planejamento e cotidiano. São Paulo: Contexto, 2001.

ZUKIN, Sharon. Paisagens do século XXI: notas sobre a mudança social e o espaço urbano. Em: ARANTES, Augusto (org.) O espaço da diferença. Campinas: Papirus, 2000.

\subsection{Web Sites}

A ARCA. Disponível em: <http://www.a-arca.com/v2/artigosdt.asp? sec=4\&ssec=1 1\&cd $\underline{\mathrm{n}=1281}$, , acesso em 7 dez. 2004.

BALLONE, G. J. - Linguagem. Em: PsiqWeb Psiquiatria Geral, Internet, 2001 -

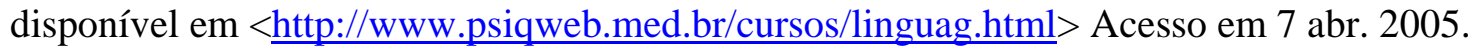

BRAMANTE, Antonio Carlos. Recreação e Lazer: concepções e significados. Disponível em: <http://www.unicamp.br/fef/grupos/gale/bramante/texto2.html>, Acesso em 7 abr. 2005.

BREVE HISTÓRICO DA LINGUAGEM, DE BABEL A NOSSOS DIAS. Disponível na em: <http://www.aticaeducacional.com.br/htdocs/Especiais/hist_ling/> Acesso em 7 abr. 2005.

RAGGI, Roberta Vieira. Apropriação de Áreas Públicas em Belo Horizonte com Enfoque no Parque J.K. Disponível em: < $\underline{\text { http://www.parque-jk.hpg.ig.com.br/Educacao/9/index }>}$ Acesso em 6 abr. 2005.

PLAYING GAMES. Disponível em < $\underline{\text { http://www.rpg.com.br/index.php?categoria= }}$ $\underline{3 \& i d=448}>$ Acesso em 21 mar. 2005. 
ZAVALA, Rodrigo. Tempo livre dos jovens não é construtivo. Disponível na Internet em:

$<$ http://ral-

adolec.bvs.br/scielo.php?script=sci arttext\&pid=S141471302002000200008\&1

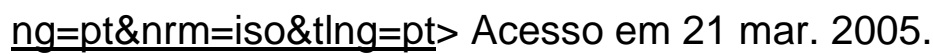

\subsection{Periódicos}

ANDRADE, Flavio. Jogo do Demônio. Em: Revista Dragão Brasil nº 53. São Paulo: Trama, 1999.

KLIMICK, Carlos. RPG para não-rpgistas. Em: Revista Dragão Brasin nº 67. São Paulo: Trama, 2000.

REVISTA DRAGÃO BRASIL. São Paulo: Talismã. ano X, n. 109, dez. 2004 RIBEIRO, Fernanda. A Camarilla: conheça o maior fã-clube mundial do Mundo das Trevas. Em: Revista Dragão Brasil nº 99. São Paulo: Talismã, 2003.

\subsection{Bibliografia Complementar}

ANDRADE, José Vicente de. Fundamentos e Dimensões. 7 ed. São Paulo: Ática, 2000.

BARSA PLANETA INTERNACIONAL. Dicionário Eletrônico Barsa: Língua portuguesa. São Paulo: Barsa Planeta Internacional, 2004. CD-ROM.

CAMARGO, Luiz O. Lima. O que é lazer? São Paulo: Brasiliense, 1986.

DUMAZEDIER, Joffre. Sociologia Empírica do Lazer. São Paulo: Perspectiva, 1980.

FERREIRA, Aurélio Buarque de Holanda. Miniaurélio Século XXI Escolar: o minidicionário da língua portuguesa. Rio de Janeiro: Nova Fronteira, 2001.

KOOGAN, A., HOUAISS, A. Enciclopédia e dicionário ilustrado. São Paulo: Delta, 1994.

O QUE É RPG. Disponível em: <http://www.portaldoelisio.com/rpg/historia.htm> Acesso em 07 dez. 2004.

REVISTA DRAGÃO BRASIL. São Paulo: Trama. ano IV, n. 45, dez. 1998 . . São Paulo: Trama. ano V, n. 53, ago. 1999. . São Paulo: Talismã. ano VIII, n. 99, set. 2002. 
RICON, Luiz Eduardo.. Palavra de Bandeirante - RPG se faz em grupo. Rede RPG ( on line] São Paulo Abril/ 2004 Disponível em: <http://www.rederpg.com.br/portal/modules/ soapbox/article.php?artID=53>, Acesso em 07 dez. 2004.

RODRIGUES, Adyr Balastreti. Turismo e espaço: Rumo a um conhecimento transdisciplinar. São Paulo: Hucitec, 1997.

SVALDI, Rafael dei. Uma Nova Saga Começa. Disponível em: < $<$ http://www.sobrecarga. com.br/node/view/354> Acesso em 07 dez. 2004.

SOUZA, A. M., CORRÊA, M. V. M. Turismo - conceitos definições e siglas. 2.ed. Manaus: Valer, 2000.

UM POUCO DA HISTÓRIA DO RPG. Disponível em: < http://members.tripod.com/ حZIPrpg/rpg/umpouco.htm> Acesso em 07 dez. 2004. 


\section{APÊNDICE}

\section{Coleta de dados}

\section{Entrevista}

Roteiro de entrevistas para os profissionais, estudiosos e jogadores de RPG

O objetivo desta entrevista é conhecer o perfil do praticante de RPG, quais suas motivações e como se dá a relação e o comportamento destes. Pretende ainda, compreender o como o jogo tem se tornado uma opção de lazer para jovens e adultos do Distrito Federal e como se dá a expansão entre este público.

Entrevistado Data:

Profissão

Envolvimento com o

RPG

1- Como e quando você descobriu o RPG? Por que continua jogando? Qual a importância deste na sua vida?

2- Para você, qual é o perfil do jogadores de RPG? Qual a idade, sexo predominante, como se vestem, como se comunicam, o que tem em comum além do RPG?

3- Você concorda que o RPG é muito popular entre os jovens? Na sua opinião qual a razão disto?

4- Como seus familiares e amigos vêem o jogo? Qual a opinião deles? Você concorda com eles? Por que?

5- Em que aspectos da sua vida pessoal o RPG tem contribuído? E de que forma? 


\section{Entrevista 1}

Roteiro de entrevistas para os profissionais, estudiosos e jogadores de RPG

O objetivo desta entrevista é conhecer o perfil do praticante de RPG, quais suas motivações e como se dá a relação e o comportamento destes. Pretende ainda, compreender como o jogo tem se tornado uma opção de lazer para jovens e adultos do Distrito Federal e como se dá a expansão entre este público.

Entrevistado: Bruno Benitz Data: 31/ 03 / 2005

Envolvimento com o RPG: Coordenador nacional do projeto Brasil By Night, organização que promove jogos de RPG live action.

1- Como e quando você descobriu/ conheceu o RPG? Por que continua jogando? Qual a importância deste na sua vida?

Eu sou novato no rpg, apesar de tudo, é que eu sou meio obsessivo em tudo o que eu faço. Eu comecei a jogar rpg, acho que foi no ano de 2000, mais ou menos, foi a primeira vez que eu fui jogar. Não joguei, fiz a ficha só, na casa do Junior. Um amigo meu. Fiz a ficha, não joguei, depois eu fiz uma partida de D\&D, pela metade. Só voltei a jogar em 2002 no By Night, entrei como jogador, me divertir bastante, adorei, já conhecia algumas coisas, mas nunca tinha jogado live, nunca tinha jogado num projeto, não... já tinha jogado uma campanha na casa de um amigo também, mas também não joguei muito, levou umas quatro ou cinco sessões. E comecei no BBN, comecei a jogar... eu sempre sou muito obsessivo, comecei a ler tudo, comecei a ler muito material, aí o BBN parou, voltou com a nova diretoria e eu era o único jogador do clã tremere e comecei a... tudo ficar em mim, com a mudança de diretoria eu virei narrador, depois diretor e... bem...e... fiquei, né?

Como narrador estou a pouco tempo, sou mais diretor, hoje apesar do pouco tempo, que é até mais do que algumas pessoas... coordenando a parte que eu gosto, que é a tremere (...) hoje, é na direção que estou, tenho bastante responsabilidade no By Night, é uma responsabilidade que eu assumi, eu não consigo deixar de lado, eu assumo a responsabilidade, então, é bastante importante, toma bastante meu tempo, eu tenho pouco tempo pra jogar... jogar jogo de mesa, outros jogos... por que quase todo o meu tempo dedicado ao rpg eu sou mais pelo By Night, mas eu tento... eu jogo outros jogos, eu tava indo jogar no Afterlife, jogo jogos de mesa com amigos, tô num live de lobisomem, hoje o rpg pra mim é a válvula de escape, apesar do by night estressar bastante nos momentos de organização, na parte organizacional, no controle de narração, ainda é divertido...

2-Para você, qual é o perfil dos jogadores de RPG? Qual a sua idade, o sexo predominante, como eles se vestem, como se comunicam e o que têm em comum além do RPG? 
É engraçado isso ai, por que, apesar de ser bastante comum, ter muita gente do rock, ter muita gente de preto no rpg, se você der uma olhada tem pessoas completamente... é um grupo muito eclético.

O "Catu”, que é ex-diretor, na primeira vez que uma jogadora foi jogar conosco foi pegar um carona com ele, encontra o cara de shortinho, jogador de futebol, camiseta, óculos escuro na cabeça, e parecendo um pagodeiro, ela esperava encontrar um rockeiro né? Que é a imagem esteriotipada do jogador de RPG. Não tem então... acho difícil esteriotipar... dar... qualquer é o padrão. Tem muita gente do rock? Tem muita gente que se veste de preto? Tem! Mas não quer dizer que são todos, eu conheço muita gente que faz parte de outros grupos de rpg.

Eu conheço jogador desde 14 e 15 anos como conheço o Adriano, de Curitiba, que é um dos diretores do By Night que tem 42.

A faixa etária é de 20 a 30 anos, é a maior parte, eu creio que seja, mas tem gente de todas as idades, meu ex-chefe já falou uma vez que o sobrinho dele foi narrar pra ele só que demorou tanto que ele não conseguiu esperar.

3-Você acredita que o RPG é muito, ou até mesmo mais popular entre os jovens? Na sua opinião qual a razão disto? Teria alguma coisa haver com a necessidade de dedicação e demanda de tempo por parte do jogador?

Não sei, mesmo por que a maioria dos jogadores hoje trabalham, estudam e ainda jogam, não sei se é a demanda de tempo, porque aí quando você tem casa, filho, você tem prioridades que acabam entrando na frente,eu tenho filho, já fui casado, sei como é, nessa época eu não joguei, foi justamente nessa época em que eu entrei nesse buraco que eles começaram a jogar, e entrar no By Night, então eu...

É o principal... você tem o trabalho, tem o estudo, mas você tem um certo tempo livre, você não precisa estudar, levar filho pra passear, ou quando tem, como eu tenho, você consegue encaixar, você sabe que é casado, a não ser... há um caso, esse próprio Adriano, são casados, tem filhos, e conseguem.

Acho que a grande coisa dos mais velhos é a imagem dessa coisa de criança, da brincadeira, mesmo quando a gente tenta levar a serio, mesmo quando a gente tentar fazer uma coisa toda mais seria, sempre rola: ah... é coisa de criança, pô!

A gente tá tentando fazer um projeto sério no By Night, tá tentando fazer um projeto pra ajudar deficientes, a maioria das pessoas acha que é uma brincadeira de jovens que não tem mais o que fazer e que daqui pouco vão abandonar tudo, não é bem assim, prioridades que eu notei...

Aí as pessoas vão ficando mais velhas e vão querendo manter, "não, não, eu não posso ser mal visto, tô jogando rpg, vão falar que eu sou estranho, sou isso, isso, aquilo" aí para de jogar, talvez seja isso, eu não sei, não passei ainda. Por isso, sou moleque ainda.

4-É verdade que o Jogo se concentra em grupos específicos que costumam ter a mesma linguagem, expressões e linhas de pensamento em comum?

Bem, isso não é só no rpg, qualquer grupo, qualquer tribo, isso acontece, entre os esportistas isso vai acontecer, entre os skatistas isso vai acontecer, dentro do possível, 
tenta-se mesclar os grupos, por exemplo, eu tenho meu grupo de rpg, que funciona... que eu jogo mais, mas todas as pessoas que jogam, em algum momento ou outro a gente vai jogar junto no by night, isso acontece muito, entrar gente de vários grupos, e ai acaba trazendo mais um, mais um, e outro amigo.

Agora criar linguagem, isso acontece com qualquer grupo que anda muito tempo junto, qualquer tribo faz isso, mesmo a turma da mesma rua, vai criar piadas internas que só aquele grupo vai entender, uma criação de estilo, não se isso é só especifico do rpg, mas uma coisa do próprio ser humano, qualquer grupo que se reúne, cria coisas especificas, coisas daqueles grupo, linguajar, corporal e oral.

5-É possível dizer que o Jogo e seu fascínio influenciam a vida dos jogadores de forma significativa, afetando, por exemplo, suas relações sociais?

Depende, é difícil falar sobre isso, por que ao mesmo tempo que aquele louco que entrou lá atirando, por que viu o negocio do Marilin Manson... eu não gosto do Marilin Manson.... mas uma coisa não tem nada a ver com a outra... ajuda na socialização, sim eu não tenho duvidas, você é obrigado a... durante o live... obrigado entre aspas, a conversar com pessoas que você não conhece, é uma coisa muita boa contra timidez, que muita gente tem, muito parecido com o teatro, você é forçado a interagir a botar sua cara a tapa, a falar, eu mesmo, vou lá na frente, tem quarenta, cinqüenta jogadores olhando pra mim, e tendo que falar, out game ou in game, agora mesmo, eu que sou uma pessoa tímida, mas vai desenvolvendo, dando uma certa desenvoltura.

Mas também isso é uma coisa perigosa de afirmar, ele é uma coisa muito significativas que você vai tomando razão de coisa ruins que acontecem é por causa do rpg, que ele pode influenciar, pode, mas... ele não vai te transformar, você não vai se tornar uma pessoa que você não é.

6-Na sua opinião é correto afirmar que apesar da gratuidade do jogo e do fascínio lúdico que o mesmo possui, o RPG não consegue se tornar muito popular?

A gratuidade entre aspas, né? É uma coisa cara, os livros são caros, cultura no Brasil em geral é caro, cinema, teatro, literatura, inclusive os livros de rpg, é uma coisa cara.

Tem uma serie de publicações em inglês, muita livros são em inglês, aqui mesmo no live, apenas o Leis da Noite é em português, por que todos os livros que eu tenho são em inglês, as vezes tem que importar, algum amigo tem que comprar na Europa, que custa vinte dólares lá, fica caro pra comprar todos os livros, é caro.

Essa gratuidade é entre aspas, mas você consegue fazer com um livro... você consegue criar no rpg mais regras, essas regras que estão nos livros, você tendo idéia do que é, você inventa na hora e sai narrando, alguma coisa qualquer com regras que inventa na hora, com dados, e fazendo regras aleatórias, a direção não é o tempo todo conhecendo todo o material, mas é caro, acho essa gratuidade entre aspas, até por que por exemplo, você vai jogar, você vai gastar dinheiro com uma serie de coisa.

Você tem que comprar o lanche pra levar pro grupo, a coca-cola pra todo mundo tomar, jogador de rpg toma coca-cola até não poder mais, é uma atrás da outra, a gente devia ganhar patrocínio da coca-cola pra jogar, tem que pagar lanche, locomoção, eu por 
exemplo, meu grupo mora longe de mim, tive que dormir na casa de amigo, é complicado voltar pra casa. Eu não tenho um grupo perto de mim, custa caro, creio que essa gratuidade entre aspas, apesar de ser mais barato que outras coisas, por que maioria das coisas em Brasília é muito cara.

Talvez... eu acho... ele é popular, muita gente que você nem espera que joga e vai conversar com a pessoa ela joga já tem conhecimento, é mais a questão do custo do livro, e falta do material em português, por que há um problema sério de cultura no Brasil, quanto mais em outra língua, está vendendo em outro idioma, acho que afeta, o custo dele, a gratuidade é bem subjetiva, nesse caso do rpg, é uma diversão, como qualquer outra coisa cultural no Brasil, custa caro.

Subjetivamente, não é uma definição formal, dos livros ou da Internet, pra mim rpg é diversão, é você tá tentando se divertir, pra espairecer, esquecer os problemas, como qualquer outra diversão que você vai fazer, tem um aspecto cultural muito interessante, você vai criar personagem, fazer pesquisas procura material, coisa bem interessantes.

$\mathrm{Eu}$ descobri coisas muito legais fazendo pesquisas pra criar personagens. A socialização é muito bom, poxa, eu conheço muita gente em Brasília agora, eu cheguei em Brasília em 99, e é uma cidade difícil de fazer amizades, já tinha terminado o segundo grau, já tava trabalhando, só tinha amigos de trabalho, e conhecia quase ninguém... inclusive, muita gente hoje eu tenho contato de trabalho eu conheci através do rpg, mas no fundo é diversão, distração, nessa coisa seria, que dá prazer, como qualquer outro hobby, como o cara que vai pra casa fazer bonsai, cuidar de jardim, é diversão, por mais seria que seja, meu avó coleciona orquídea, é trabalhoso pra ele, mas é prazeroso é divertido, é diversão mesmo levado a serio.

\section{Entrevista 2}

Roteiro de entrevistas para os profissionais, estudiosos e jogadores de RPG

O objetivo desta entrevista é conhecer o perfil do praticante de RPG, quais suas motivações e como se dá a relação e o comportamento destes. Pretende ainda, compreender o como o jogo tem se tornado uma opção de lazer para jovens e adultos do Distrito Federal e como se dá a expansão entre este público.

\section{Entrevistado:Gualter Henrique Data:14/04/2005}

Envolvimento com o RPG: Administrador local do fã clube oficial da editora White Wolf, conhecido popularmente como The Camarilla, mas registrado no Brasil sob o nome Associação Brasileira de Jogadores de RPG.

1- Como e quando você descobriu/ conheceu o RPG? Por que continua jogando? Qual a importância deste na sua vida? 
Eu conheci o rpg através de revistas de videogame, tinha uns 14 anos, eu gostava muito de jogar videogames, e lendo revistas sobre o assunto, cheguei a ler matérias sobre o rpg, me interessei um pouco, até que um dia, perguntei a um vizinho meu se ele conhecia um jogo chamado rpg, ele me disse que sim e que até tinha ganhado uma caixa com o $\mathrm{D} \& \mathrm{D}$ do pai dele de presente de natal. Foi aí que comecei a jogar, como ninguém estava disposto a ler os dois livros que vinham na caixa, eu comecei a ler e também já mestrei, isso foi interessante, por que a maioria dos mestres de rpg começa primeiro jogando, pra depois conhecer melhor o jogo e aí sim passar a mestrar, eu não, fui logo de cara mestrar.

Eu continuo jogando por que isso me faz bem, eu gosto do jogo por vários motivos, o principal deles é a diversão, também tem a oportunidade de conhecer novas pessoas, de aprender novas coisas, e de ser o que você quer fora dessa realidade.

O rpg é muito importante na minha vida, sinceramente, antes de conhecer o rpg, eu sempre queria conhecer algum jogo de videogame que fosse totalmente interativo, que eu mesmo determinasse os rumos do jogo, sabe? Ter liberdade de escolher o que fazer, mesmo sem saber na época que existia o rpg, eu já queria conhecer algo desse tipo, o rpg me deu uma oportunidade de mais ou menos fazer isso, ser o que você quiser, fazer o que tiver que fazer dentro do jogo, mas sem ações pré-determinadas, por que os jogos de videogame são isso, você tem que pular, chutar, atirar e fazer exatamente o que o produtor do jogo estipulou, senão você não ganha, já no rpg, as situações são propostas e você deve escolher a melhor forma de fazer ou de até não fazer. Depende do que você quer.

2-Para você, qual é o perfil dos jogadores de RPG? Qual a sua idade, o sexo predominante, como eles se vestem, como se comunicam e o que têm em comum além do RPG?

Bom, o perfil dos jogadores varia bastante, apesar que antes, há alguns anos, você só encontrava jogador mais ou menos dos mesmos grupos, hoje em dia o rpg está mais difundido, mais eclético, tem muita gente que faz estilo alternativo que joga rpg, muitos rockeiros, a maioria é rockeiro, não sei bem por que, mas quase todo mundo que gosta de rpg, gosta de rock. A idade dos jogadores é em media dos 20 anos, é claro que tem gente mais velha, e gente mais nova, eu mesmo já conheci crianças de 9,10 anos que jogam, e também conheci gente de São Paulo que tem mais de 30 e jogam muito.

Sem duvidas que o sexo predominante é o masculino, apesar de que há também mulheres que jogam, e não são poucas, mas a maioria é homem, acho que por que homem gosta mais de jogar do que mulher, os homens levam mais a serio o jogo, a maioria das mulheres jogar por causa de outros motivos, não que elas não joguem, mas eu já percebi que quase uma garota jogar por que os amigos jogam ou por que o namorado joga, mais aí elas acabam gostando do jogo.

Quanto a vestimenta, acho que não há um padrão pré-estabelecidos para os jogadores de rpg, acho difícil você encontrar alguém na rua que você consigo identificar como jogador de rpg analisando a sua roupa, só se a camisa dele tiver alguma referencia ao jogo de rpg. Quanto a comunicação, posso dizer que há um certo “dialeto” entre os jogadores de rpg, pois só quem joga conhece os termos técnicos do jogo, e jogador de rpg se amarra em sair falando em CA, que é classe armadura, DX, que é destreza, PV que é ponto de vida, e outras coisas mais que fazer parte do jogo. Tem gente que passa e fica olhando os caras falando de matar monstros, e de espadas vorpal + 3, e não entende nada. 
Bom, resumindo, os jogadores tem sim uma linguagem própria pra falar do jogo e só quem joga e que sabe o que está falando.

Bom, em comum alem do jogo é difícil de dizer, por que dentro dos grupos de jogos vão se criando laços de amizades e companheirismo que só mesmo o tempo para dizer o que as pessoas tem em comum alem do jogo.

3-Você acredita que o RPG é muito, ou até mesmo mais popular entre os jovens? Na sua opinião qual a razão disto? Teria alguma coisa haver com a necessidade de dedicação e demanda de tempo por parte do jogador?

Ah, com certeza sim, o rpg é muito popular entre os jovens, até mesmo por que o jovem é muito mais receptivo as novidades do que as pessoas mais velhas. Eu acho muito difícil algum amigo dos meus pais chegarem lá em casa convidando meus pais para jogar rpg, e o mais difícil ainda seria eles aceitarem. Acho que a razão de ser mais popular entre os jovens vem daí, da vontade de conhecer novas coisas e de ser receptivo a elas. Bom, o tempo até que influencia um pouco, os jogadores de rpg, tem que ter tempo para jogar, senão não jogam, por que as partidas geralmente duram cerca de 4 ou cinco horas, geralmente nos finais de semana.

4-É verdade que o Jogo se concentra em grupos específicos que costumam ter a mesma linguagem, expressões e linhas de pensamento em comum?

Acho que não, se bem que, isso até pode ser verdade, mas não é assim tão rígido, por que eu acho que pra alguém querer jogar rpg, basta ter vontade de conhecer, pode ser que o cara nunca tenha ouvido falar disso antes, não é difícil acontecer, mas o que ocorre muito, é um certo receio que muitas pessoas possuem de conhecer algo de novo, algo que é estranho a sua realidade, eu mesmo já vi, muita gente dizer que não joga rpg por que é coisa do demônio, sendo que essa pessoa nunca nem sentou numa mesa de jogo pra saber como é. Mas acontece de pessoas jogarem e não se interessarem mais pelo jogo, assim como acontece em qualquer atividade.

Mas deve sim acontecer de somente as pessoas que tem um pensamento em comum jogarem rpg. Mas acho que isso acontece em qualquer lugar.

5-É possível dizer que o Jogo e seu fascínio influenciam a vida dos jogadores de forma significativa, afetando, por exemplo, suas relações sociais?

Com certeza, sim, a influencia que o jogo exerce sobre os jogadores é muito grande, até mesmo porque, ele passa a ter novas relações sociais, eu mesmo, no segundo, conheci muita gente através do rpg, que acho que com certeza não conheceria se não fosse o jogo. Até mesmo por que, as pessoas que conheciam não freqüentavam os meus círculos de amizade. Acho que essa influencia é boa, talvez para alguns possa ser negativa, mas isso vai depender da personalidade de cada um, ninguém precisa deixar de ter amigos que não jogam rpg. Apesar de que depois que você começar a jogar, você quer que todos os seus amigos joguem. 
6-Na sua opinião é correto afirmar que apesar da gratuidade do jogo e do fascínio lúdico que o mesmo possui, o RPG não consegue se tornar muito popular?

Bom, gratuito, o jogo não é, por que os livros custam caro, chegar aos locais de jogos custa dinheiro, seja com ônibus ou gasolina. Pode ser que alguns jogadores, privilegiados, não tenha que gastar dinheiro comprando livros ou pegando ônibus, mas isso são poucos, mesmo por que todos os grupos de jogos que conheço sempre fazem vaquinhas pra poder comprar os livros, os dados e os suplementos dos jogos.

Acho que o rpg ainda está se desenvolvendo, a ponto de se tornar realmente popular, eu tenho quase certeza que daqui há uma ou duas gerações, o rpg será conhecido quase que por todos, como o videogame é hoje em dia, é só uma questão de tempo. 


\section{Questionário}

Questionário destinado aos jogadores de RPG para conhecê-los e traçar um perfil dos mesmos.

Pesquisa sobre o lazer no Distrito Federal

Prezado Senhor (a),

O objetivo desta pesquisa é conhecer e identificar os jogadores de RPG e suas motivações para tal prática. A identificação de V. Sa. não é necessária uma vez que as interpretações dos dados aqui recolhidos serão feitas de forma global. A sua colaboração é fundamental para o sucesso deste trabalho.

1 - Local da entrevista:

Data

( ) Loja Kingdom Comics

( ) Loja Mundo do RPG

( ) SESC 504 SUL

( ) Locais de realização de jogos

2- Sexo: ( ) M ( ) F

3- Estado Civil:

( ) Solteiro

( )Casado

( ) Viúvo

( ) Desquitado

( ) Outros

4- Faixa Etária:

( )12 a 19 anos

( ) 40 a 49 anos

( )20 a 29 anos

( ) 50 a 59 anos

( )30 a 39 anos

( ) acima de 60 anos

5 - Grau de escolaridade: 
( ) $1^{\circ}$ grau incompleto

( ) $1^{\circ}$ grau completo

( ) $2^{\circ}$ grau incompleto

( ) $2^{\circ}$ grau completo

( ) Superior incompleto

( ) Superior completo

6- Ocupação atual::

7- É a primeira vez que joga? ( )Sim ( )Não

8- Quanto tempo dura, em média, as sessões de jogos?
( ) 1 hora
( ) 2 horas
( ) 4 horas
( ) 3 horas
( ) 5 horas
( ) 6 horas ou mais

9- Qual a freqüência de jogo, semanalmente ?
( ) 1 vez
( ) 4 vezes
( ) 2 vezes
( ) 5 vezes ou
( ) 3 vezes mais

10- Quanto tempo dura, em média, as sessões de jogos?
( ) 1 hora
( ) 4 horas
( ) 2 horas
( ) 5 horas
( ) 3 horas
( ) 6 horas ou mais

11- Com quantas pessoas, geralmente, costuma jogar?
( ) 1 pessoa
( ) 4 pessoas
( ) 2 pessoas
( ) 5 pessoas
( ) 3 pessoas
( ) 6 pessoas ou mais

12- Tem envolvimento com alguma organização ou projeto relacionados ao RPG?

( ) Não ( ) Sim

Qual?

13- Se pudesse mensurar, qual o nível de importância do RPG em sua vida?
( ) nenhuma
( ) grande
( ) pouca
( ) muito grande 

( ) média
( ) extremamente

importante

14- Explique em poucas palavras, por que você joga RPG?

Muito Obrigado!

ANEXOS 